MASS. EA31.2: D443/5

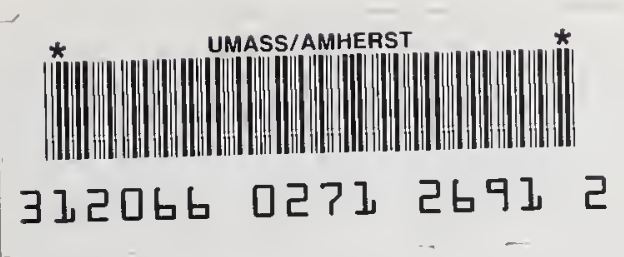

\title{
DEVELOPMENT AND EVOLUTION OF THE SEA SCALLOP FISHERY MANAGEMENT PLAN
}

\section{GOVERMMENT DOCUMENTS COLLECTION \\ JAN 4 - 1984 \\ University of Massachusetts \\ Depository copy}

\author{
David E. Pierce
}

\author{
Massachusetts Division of Marine Fisheries \\ 100 Cambridge st. \\ Boston, MA 02202
}

Funded by the New England Fishery Management Council

Publication \#: 13232-75-50-5-83- C.R.

Approved by John J. Manton, state Purchasing Agent 
Digitized by the Internet Archive in 2012 with funding from

Boston Library Consortium Member Libraries

http://archive.org/details/developmentevol00pier 
In December 1976 a Draft Environmental Impact Statement/ Fishery Management Plan (DEIS/FMP), prepared by the Regional office and the Northeast Fisheries Center of the National Marine Fisheries Service (NMFS), was published for the Atlantic Sea Scallop. As stated in the Draft,

\begin{abstract}
"The purpose of the Management Plan is to manage the sea scallop fishery off the coast of the U.S. for optimum sustainable yield and to allocate harvest between domestic and foreign fishermen. The plan recommends that there be no decision on the total allowable level of foreign (Canadian) fishing until a U.S.-Canadian agreement is consummated, and that this agreement, and the unique joint concern for the Atlantic sea scallop resource by the U.S. and Canada form the basis for any future decisions".
\end{abstract}

The Draft Plan was essentially a background document for state Department negotiations with Canada on Georges Bank scallops. With both the U.S. and Canada extending their jurisdictions to 200 miles thereby creating a disputed zone of overlapping authority, joint collaboration for cooperative management was being pursued.

The Preliminary Management Plan (to be effective March 1 , 1977 - Fishery Conservation and Management Act implementation date) also was necessary since, as specified by the FCMA, the Secretary of Commerce had to prepare Plans to provide estimates of optimum yields, determine total allowable levels of foreign fishing (if any) and set permit and data reporting requirements for foreign vessels. Moreover, there was concern about overfishing. According to the Draft,

"... Recent declines in catch per unit effort indices and increases in fishing mortality suggest that abundance of Georges Bank sea scallop stocks is declining. Landings of Georges Bank scallops during the past two years have exceeded the 'equilibrium level' of about 6,000 metric tons (MT) of meat weight reached for the fishery after 1965, implying that management measures should be enacted to reduce overfishing and insure future favorable spawning stock levels...., and.. it is apparent that growth overfishing has already transpired. If present effort levels and low cull sizes (small scallops) continue, the prospect of stock depletion (recruitment overfishing) is critical. Accordingly, future management measures should be directed at significantly reducing fishing effort and increasing the age at first harvest." 
A fishing mortality of approximately 67\% (percent stock removed each year due to fishing), representing a most recent (1972) estimate, was judged too high, and it was suggested that "if fishing mortality were reduced towards $25 \%$ and the first age of harvest increased to greater than age four to take advantage of scallop growth and low natural mortality of $10 \%$, long-term yield would be increased and would decrease the probability of recruitment failure".

Suggested Georges Bank (ICNAF Area 5Z) (Figure 1) management measures for both U.S. and Canadian fleets were:

1) limit combined U.S. and Canadian catch to approximately 6,000 MT (estimated Maximum Sustainable Yield):

2) allocate the 6,000 MT between the U.S. and Canada according to recent catch percentages;

3) by 1982 phase in a meat count of 25 to 30 meats per pound;

4) consider limited entry for new vessels;

5) consider a closed season during late winter and early spring to protect small, newly recruiting scallops.

The Plan also suggested that regulations for sea scallops in the Gulf of Maine (5Y) and in the mid-Atlantic Bight (Area 6) might (emphasis added) be needed.

In addition to the suggested measures, the Plan proposed a continuation of average meat per pound (meat count) and minimum shell size restrictions implemented by the U.S. on August 31,1976 . These restrictions were:

1) a prohibition of retention and landing of meats in excess of an average count of 40 per pound except that the average count in possession on board a vessel at sea or at time of offloading could exceed the limit by a maximum of $10 \%$;

2) a prohibition of retention and landing of sea scallops with shell sizes of less than 95 millimeters (mm) (approximately $33 / 4$ inches) except that $10 \%$ of the amount retained on board a vessel or at the time of offloading could be below the limit.

These regulations resulted from a 1972 ICNAF/Canadian proposal later modified (10\% exemptions) at a June 8-23, 1976 International Commission for the Northwest Atlantic Fisheries (ICNAF) annual meeting. 
Figure 1

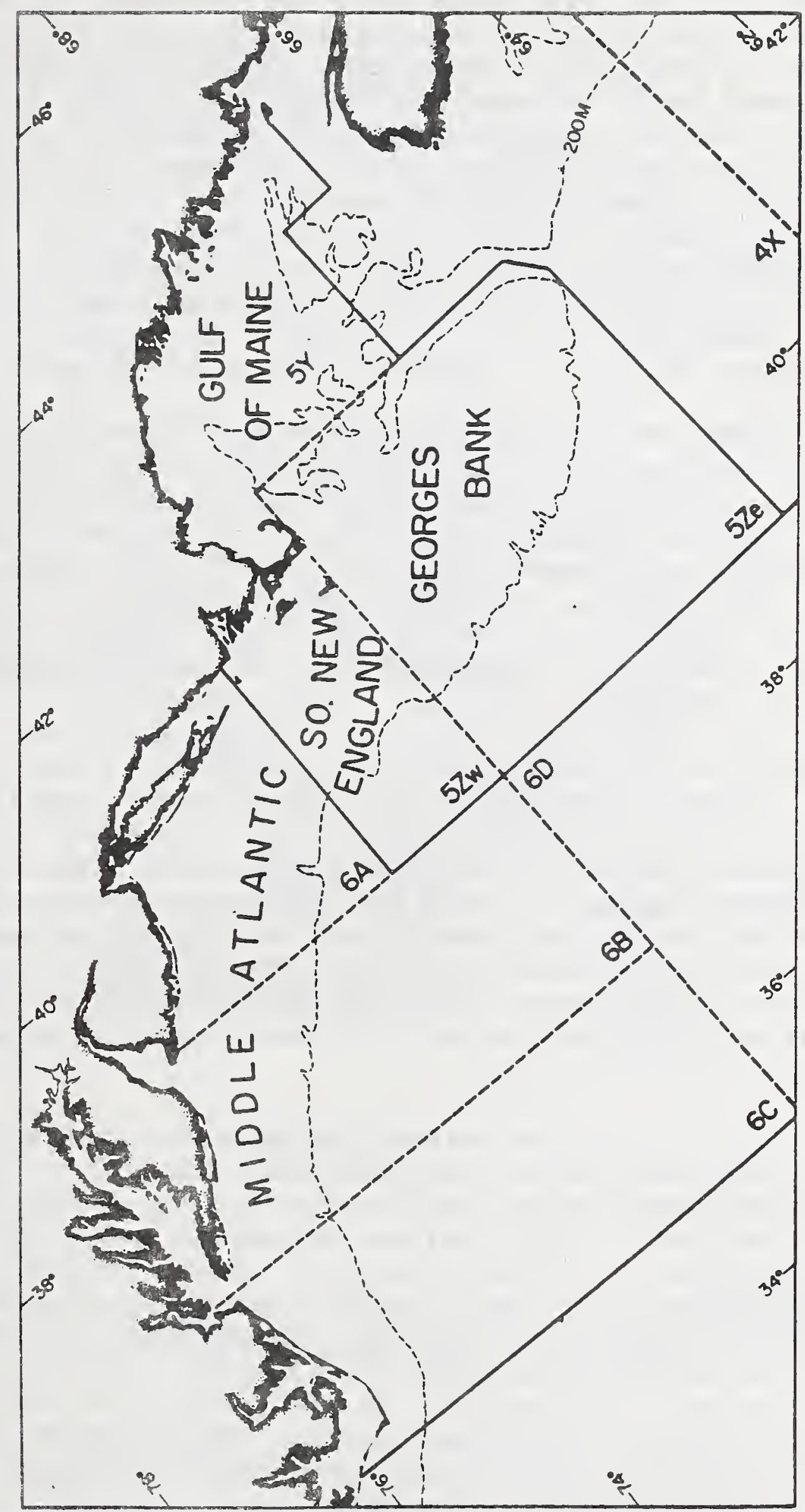

Source: Anderson et al. 1979 
Earliest Council efforts

In a January 14, 1977 letter of transmittal of the Preliminary Management Plan (PMP) to the New England as well as Atlantic Councils, William Gordon, then Regional Director of reiterated that the Plan was in support of U.S. negotiations with Canada and noted that the Plan's fate depended on the outcome of those negotiations which were to occur from January 17-30, 1977. According to Mr. Gordon, the Plan had the potential to become either "the PMP governing the Canadian scallop fishery in undisputed U.S. waters in 1977, or the basis for Councils to assume the task of development of a PMP for 1978 or a subsequent year". He also stated that time pressures prevented NMFS from discussing the PMP with industry or Council members and he hoped that time could be found for review and input before final actions were taken.

The New England Council initiated its discussions on sea scallop management at its January 25 and 26, 1977 meetings. The Regional Director reviewed the PMP and recommended that the Council develop its own Plan based on the PMP in cooperation with industry to ensure that industry needs were not overlooked. However, he suggested the Council not proceed with Plan development until the U.S./Canadian negotiations were settled. The Council agreed and postponed further discussion on the issue.

Relatively soon thereafter, at its March 9 and 10 meetings, the Council decided to proceed with development of its own Scallop Plan. In the Council's opinion, the NMFS Scallop PMP was "not much concerned with the domestic fishery or the stocks of Georges Bank." There were no regulations off southern New England or in the Mid-Atlantic Bight; hence, the Council did not endorse the PMP. Furthermore, the U.S./ Canadian Bilateral Agreement negotiated in March only maintained the status of the fishery in the disputed area (Figure 2).

Shortly after March meetings, at the Council's request, services of NMFS personnel, specifically Dr. John Posgay (NEFC) and John Linehan (New Bedford Liaison) - two individuals knowledgeable on the scallop resource and fishing industry - were offered to the Council. These individuals, responding to directions from Spencer Apollonio, then Executive Director of the Council, began an undertaking by the Council and its staff to augment the biological description of the resource and information on the nature of the fishery in New England and mid-Atlantic areas. This effort was part of a hoped for speedy development and implementation of a Council Scallop Plan addressing needs and concerns of the long established New England and rapidly growing MidAtlantic scallop fishing fleets and responding to conservation of the resource along the Atlantic coast. The Council expected to have the Plan well developed by July 1977. 
Figure 2

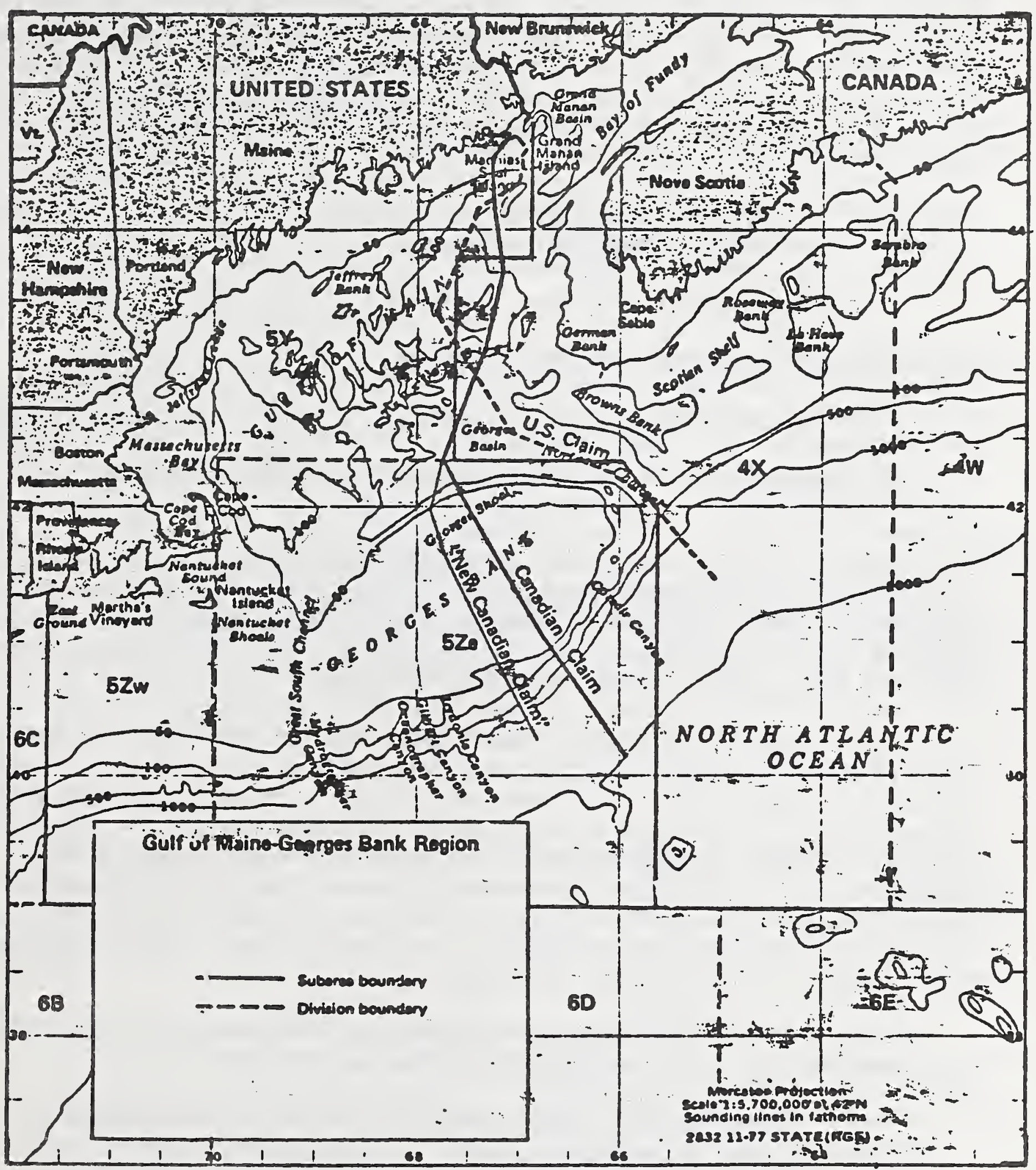

Disputed Zone between the U.S. and Canada 
Scallop Plan objectives

To provide for a coordinated effort for Plan development, a Scallop Committee was created at May 23 and 24, 1977 Council meetings. The Committee with Philip Coates, then Assistant Director of the Massachusetts Division of Marine Fisheries, as Chairman, was asked to quickly develop management objectives, and the committee obliged the council's request by proposing tentative objectives at July 5 and 6 Council meetings. These objectives were for the "Georges Bank stock":

1) maintain stock size at the early 1960's level prior to heavy Canadian effort;

2) maximize yield per recruit;

and for the "Middle Atlantic stock":

1) maximize yield per recruit;

2) spread harvest over maximum possible number of years.

These objectives were evaluated by Council Staff to describe practical limitations of achieving each one and possible implications of contemplated management strategies; e.g., closed areas and/or closed seasons, a minimum shell size or meat count, and landing quotas.

Regarding the first "Georges Bank stock" objective, the Staff analysis indicated it was unrealistic because, "Uncertainties associated with variability in recruitment and carrying capacity of the environment suggest that the 1960-1963 biomass is not indicative of an equilibrium, sustainable population." The Georges Bank biomass during the early 1960's supported catches of 11,202 (1959) to 15,384 (1962) MT. Historical catch and effort data indicated that 6,000 MT was a more likely sustainable biomass.

The Mid-Atlantic stock objective focused on the following phenomenon as described by Council Staff:

"The Mid-Atlantic sea scallop fishery has historically been characterized by relatively stable, low level harvests with periodic, high intensity fishing activity occurring at about 15 year intervals when landings may increase by an order of magnitude. These periodic "bonanza" harvests, which probably owe their existence to particularly favorable conditions affecting recruitment, have typically resulted from massive reallocation of fishing effort from other species by local fishermen using bottom trawl gear. Recently, however, there has been 
significant participation by vessels from the southern New England sea scallop fleet as well as by the Canadians.

The philosophical basis for management of the MidAtlantic sea scallop resource has focused upon the periodic "bonanza" harvests."

This tentative Council objective sought to reduce fishing mortality on these "bonanza" harvests, caused by one or perhaps two consecutive strong year-classes, so that high catches over a number of years could be maintained instead of extremely high catches in a few years. In other words, the objective was aimed at preventing a "feast or famine" fishery.

A concern with this objective, as well as with the first objective for the "Georges Bank stock", was that quotas seemed logical management strategies. Scallop quotas, however, could not be based on typical stock assessments provided by scientists since data needed for assessments to estimate stock abundance and effects of fishing mortality (e.g. reliable measures of fishing effort and catch age composition) were not available for Georges Bank or Mid-Atlantic scallops. If quotas were set, as stressed by the Staff, their magnitudes would have to be decided solely on economic implications to the industry. Interestingly, with respect to the other objective for both "stocks"; i.e., to maximize yield per recruit, the Staff emphasized that increased yield could be achieved more effectively by increasing age (or size) of scallops at harvest instead of decreasing fishing mortality by perhaps imposing quotas.

Another concern with the "Mid-Atlantic" objective was its predication on the assumption that Mid-Atlantic scallops comprised a separate stock. The validity of this assumption was and still is in doubt. According to serchuk et al. (1979),

"Presently no biological evidence exists that implies stock differentiation within U.S.A. offshore sea scallop populations. Although minor growth rate differences exist between Georges Bank and MidAtlantic populations, these appear to result from differing temperature regimes rather than genetic differences."

Note: the Mid-Atlantic Council was apprised of the New England Council's progress on objectives and their representative, William Pell, was in attendance at July meetings. 
At July meetings the tentative Committee-proposed objectives were introduced to the Council. However, none were selected. Instead, the council decided to accept a count of 40 meats per pound as a management objective. It was immediately noted by Dr. Richard Hennemuth of NEFC that a 40 meat count would not provide for maximum yield per recruit; consequently, the Council referred its new "objective" to its Scientific and Statistical committee for further evaluation.

The $S \& S$ Committee responded that the adopted Council objective was a strategy and not an objective. The Committee would not provide any advice until real objectives were formulated. It did, however, recommend that NMFS be requested to. prepare a report on "biological relationships between scallop catch levels, scallop sizes at harvest, and scallop stock size to provide the Council with biological trade-offs." The $S$ \& $S$ Committee also cited the need for a study on economic and social aspects of the fishery. Almost concurrently, the Council and NMFS Regional Office Staffs began to prepare a study of costs and earnings of different components of the scallop fleet to be used in an assessment of economic impacts on fishermen caused by various management strategies.

At August 2 and 3, 1977 meetings the Council reviewed the Committee's original recommendations for objectives and assessed the wisdom of its 40 meats per pound "objective". The Staff sought to have the council reconsider its adopted measure since it was a statement of a technique and did not provide the flexibility needed for development of management options. The Council agreed with the Staff's logic and instructed the scallop Committee to make further recommendations.

Two new objectives

The Scallop Committee, utilizing Staff suggestions, revised its previous objectives. New suggested objectives were:

1) Restore the Georges Bank adult stock to that level at which relative year to year fluctuations in stock abundance, due to variation in recruitment, are minimized. And, increase the yield per recruit for each component of the scallop fishery at individual rates compatible with reasonable socioeconomic impacts on the various industry and consumer user groups (long-term objective);

2) Maximize the socio-economic net benefits from harvesting and utilization of the "bonanza" year class in the Mid-Atlantic scallop fishery (short-term objective). 
Mid-Atlantic Council representatives participated in the development of these revised objectives, and they indicated that the Mid-Atlantic Council intended to solicit input from the scallop industry it represented on other possible objectives applicable to the "Mid-Atlantic stock".

At September 7 and 8, 1977 Council meetings, the Committee's recommendations for scallop plan objectives were unanimously approved.

Mid-Atlantic Council efforts

The Mid-Atlantic Council Scallop Advisory Committee met shortly after the New England Council established its Plan objectives. Four objectives were recommended.

1) maintain and maximize employment opportunities which are fair, equitable, and encourage efficiency in utilization;

2) maintain a scallop stock above the level where survival is threatened;

3) reduce adverse environmental effects (i.e., pollution) on stock levels and utilization;

4) minimize costs of research, development, and enforcement associated with sea scallop management.

These objectives were to be discussed by the MidAtlantic Council in september and, if approved, sent to the New England Council for its consideration.

The Mid-Atlantic Council later rejected the first two Committee objectives, accepted the latter two, and adopted three additional ones. These were:

1) restore the adult stock to the level at which relative year to year fluctuations in stock abundance due to variance in recruitment are minimized;

2) increase the yield per recruit for each areal component of the scallop resource at individual rates compatible with reasonable socioeconomic impacts on the various industry and consumer user groups;

3) Maximize the socioeconomic net benefits from harvesting and use of the scallop resource.

Little progress

Sea scallops were not discussed at all by the council until its April 19 and 20, 1978 meetings. Groundfish and sea herring maragement problems were of higher priority. 
This seven month hiatus took the Council away from its original Plan implementation schedule. Even so, a Draft Plan was still anticipated to be completed by July or August, 1978. This summer completion date was expected since the Staff in cooperation with NEFC scientists had completed the descriptive aspects of scallop biology. Furthermore, descriptions of economic aspects of the New England and MidAtlantic scallop industries were completed and underway, respectively, and the NEFC stock assessment was thought to be nearly completed (not until November, 1978).

At these April meetings, the Regional Director expressed his concern over increased effort in the scallop fishery. He stated:
"If there is any fishery ripe for establishing limits on large vessels, it's scallops. The prob- lems of the large amount of new vessels entering the fishery are compounded by the fact that the fishery is being sustained by a single and ex- tremely abundant year-class, and even further com- pounded by the untenable position developing in Canada regarding scallops." (Barlow, Maine Commer- cial Fisheries May 1978).

\section{Canadian concerns}

Canada had also expressed its concerns to the U.S. government over what it perceived to be a growing U.S. scallop fishery on the northern edge of Georges Bank (Figure 2) the area responsible for the majority of Canadian Georges Bank scallop catch (disputed zone). Canada claimed that the U.S. fishery had expanded its effort by approximately $100 \%$ in that region since 1976 and was overfishing the Georges Bank stock.

The Canadian assertion that U.S. effort had increased was justified. U.S. effort on the Northern Edge and Northeast Peak of Georges Bank rose from 45 days in 1976 to 384 days in 1977 ( 339 day increase). Catch increased from 45 $\mathrm{MT}$ to $407 \mathrm{MT}$ ( $362 \mathrm{MT}$ increase). However, Canada did not mention, or perhaps did not realize, that its own effort increased in this region, from 9,335 to 11,585 days $(2,250$ days) and 8,906 to $12,669 \mathrm{MT}(3,793 \mathrm{MT})$ (data from serchuk et al. 1979). An evaluation of percent increases in effort and landings from 1976-1977 made the U.S. fishery and its impacts on the scallop resource in the disputed zone look much worse relative to the Canadian fishery's impacts. Canada wanted the U.S. to implement regulations for its scallop fisheries which theretofore were not restricted in any way except for some industry-imposed limitations and meat count/shell size restrictions effective and enforced from August 1976 to February 28, 1977 (prior to FCMA implementation datel. 
Canada felt that its interest in Georges Bank scallops was greater than U.S. interest, and it used recent catch and effort data to "confirm" its claim. It considered U.S. increased effort as an intrusion into "Canadian" traditional fishing grounds on the Northern Edge and Northeast Peak.

These Canadian concerns intensified in the spring of 1978 and in June, during a negotiating session on the 1978 U.S./Canađian Reciprocal Fisheries Agreement and boundary issues, Canada closed all its fisheries in its undisputed waters to fishing by U.S. commercial fishermen. Canada was dissatisfied with progress of negotiations and U.S. fishery management efforts and would not even consider reciprocal fishing until it was clear that a long-term agreement was in sight.

To retaliate, the U.S. closed its undisputed waters, too. This marked the end of a series of formal east coast fishery agreements with Canada first established in 1973 when the U.S. and Canada agreed to allow each other's fishermen to fish 3 to 12 miles from each other's coast. Both countries had entered into a Reciprocal Fisheries Agreement for 1977 (implemented July 26).

\section{Shifting shares}

To appreciate reasons for both U.S. and Canadian interest in control and management of sea scallops on Georges Bank (5Ze), sea scallop landings from 1956-1980 by both countries are depicted in Figure 3. The U.S. fishery dominated landings during the 1950's until about 1964. After 1964 Canadian fishermen acquired the majority of landings. This shift in percent share was attributable to:

1) development of the offshore Canadian scallop fleet in the 1950's;

2) decline in scallop abundance on Georges Bank;

3) more individual U.S. effort with accompanying higher production costs needed to maintain profitable catches on Georges Bank;

4) productive scallop beds in the mid-Atlantic found closer to home ports particularly New Bedford, Massachusetts, home of the long distance scallop fleet:

5) finfish prices began to increase thereby providing an incentive for fishermen to convert from scalloping to dragging. 

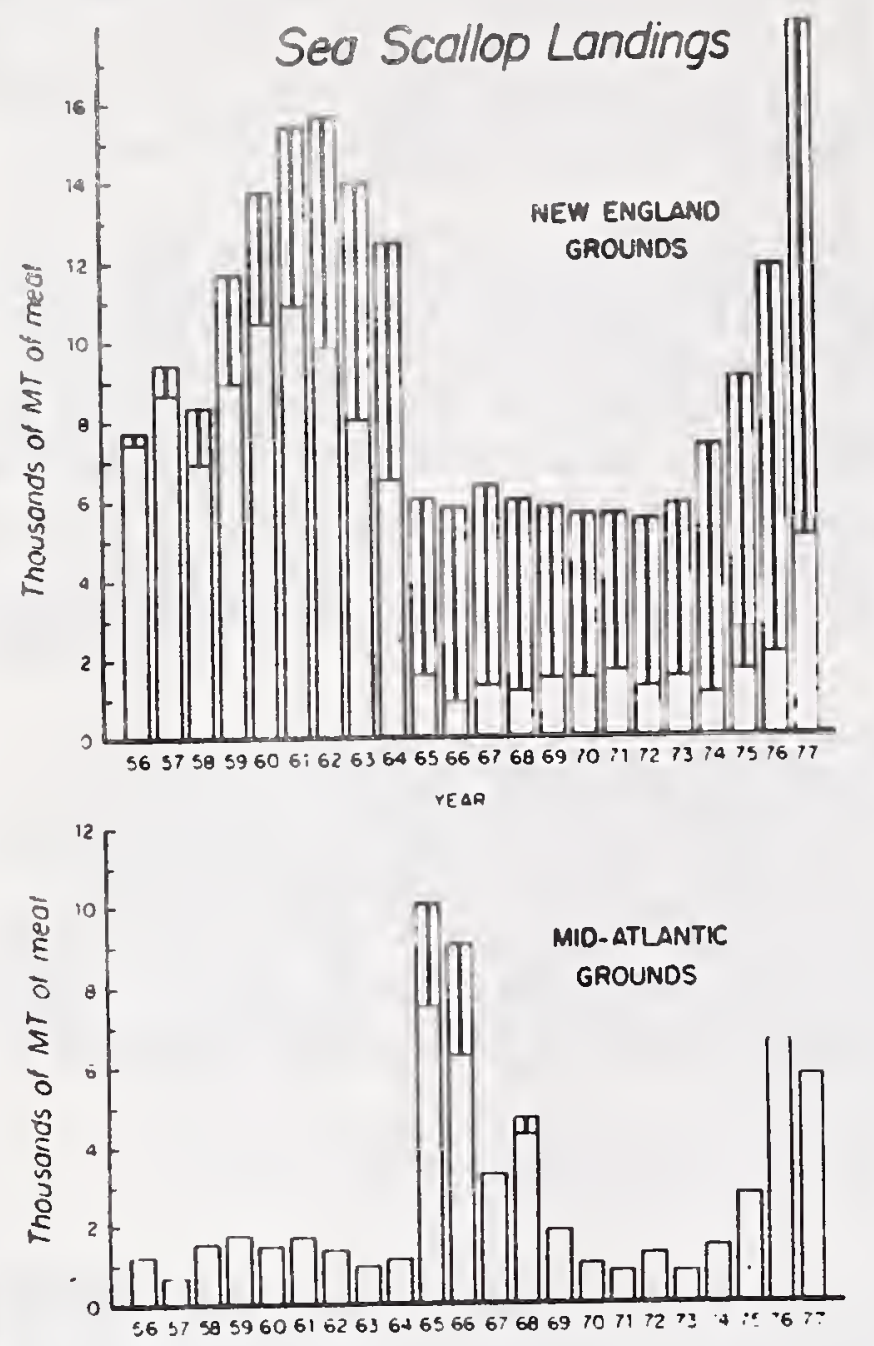

FIGURE 3. Total reported United States and Canadian sea scallop landings (metric tons, meats) from Georges Bank and Mid-Atlantic fishing grounds, 1956-1977. The upper lined portions of the bars represent Canadian landings.

\section{Figure 3}

(From serchuk, et al. 1979)

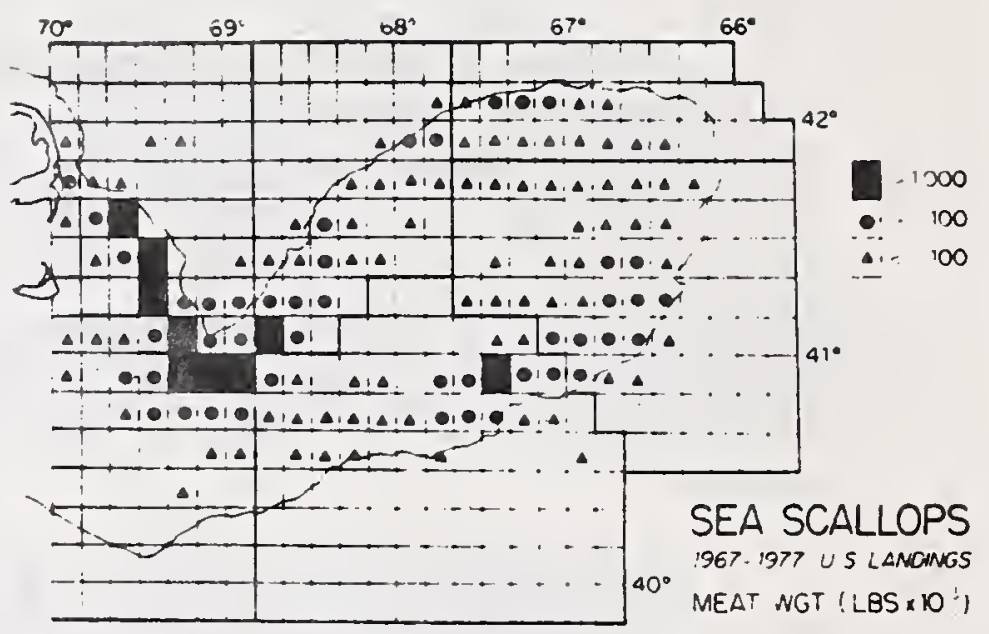

FIGURE 4. Geographic distribution of United States sea scallop landings (thousands of pounds. meats) from Georges Bank, 1967-1977.

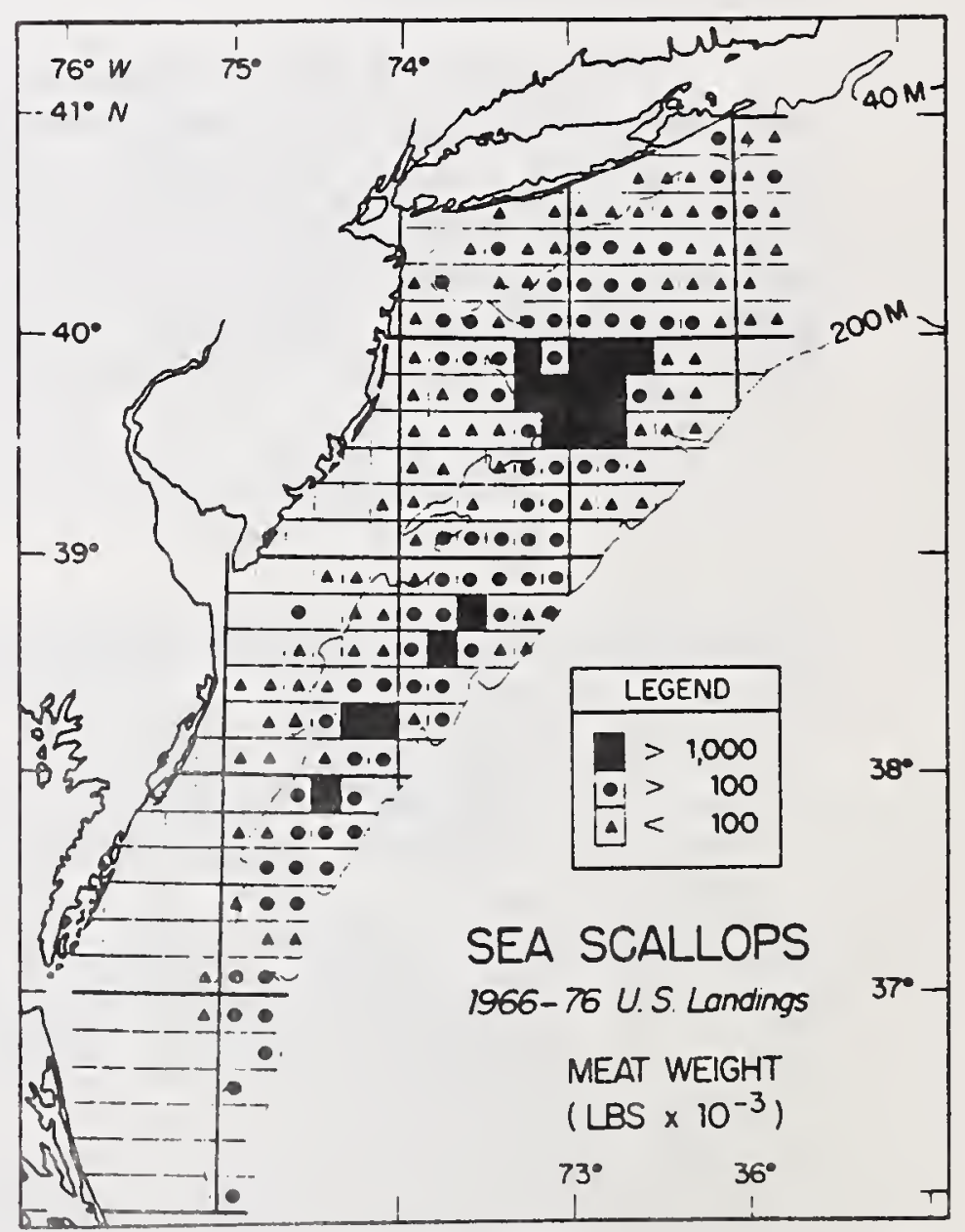

FIGURE 5. Geographic distribution of United States sea scallop landings (thousands of pounds, meats) from the Mid-Atlantic, 1966-1976. 
These five factors caused a virtual abandonment of eastern Georges Bank scallop beds by U.S. fishermen and a reduction in the offshore fleet (New England Fishery Management Council Sea Scallop Plan 1981).

U.S. catches on Georges Bank have recently increased. Catches rose from 1,760 MT in 1976 to 4,806 MT in 1977 and approximated 6,000 MT from 1978-1980. Renewed interest in this resource was primarily attributable to increased scallop prices causing draggers to convert to scalloping, and the entry of new vessels. Ex-vessel prices per pound rose from $\$ 1.62$ in 1977 to $\$ 2.47$ in 1978 and $\$ 3.28$ in 1979 (\$4.97 in 1981). Scallop availability was another reason for increased effort.. The 1972 year-class (scallops produced from 1972 reproduction) was highly successful on the Bank (and elsewhere). As described in a later section, this increased U.S. fishing caused many U.S./Canadian squabbles and played an important role in preventing ratification of the U.S.l Canadian Fisheries Treaty first proposed in early 1979.

An evaluation

While the Council did not address sea scallops until April, 1978, the Committee, Staff and others were actively involved in an examination of existing and needed biological data and research activities. One such examination occurred at a February Sea Scallop Workshop involving Northeast Fisheries Center and Staff of both Councils. The following topics were discussed: sea scallop biology; needed biological and industry data to improve assessments and economic impact analyses; evaluation of management measures as related to Plan objectives; and research priorities. Some of the more important (author's view) conclusions of the workshop were:

1) "Little is known about the factors affecting reproduction and early life history, particularly during the pelagic larval and post metamorphic stages, due to the difficulty associated with mounting relevant research efforts. The distribution of spatfall is apparently a partial function of the prevailing current patterns, making it unlikely that progeny will settle in the vicinity of the parent bed. At present there is no documented biological link between scallops in major production areas. However, similarities in population structure, in terms of the relative year class strengths recently observed between the Great South Channel and Mid-Atlantic Bight populations, may lend support to the hypothesis that the prevailing southwest current drift from Nantucket Shoals along the Mid-Atlantic Bight may result in the Mid-Atlantic beds settled by progeny from beds "up stream". 
Current research efforts include research vessel surveys (NMFS) conducted in alternate years, periodic assessments of the abundance and condition of the regional sea scallop stocks, and some on-going analysis of growth data.

2) There are three general areas where a lack of adequate data results in an inability to apply many of the standard assessment techniques to an analysis of sea scallop populations. While effort data, in terms of days fished, is available for areas $5 \mathrm{Z}$ and $\mathrm{SA} 6$, it is not considered adequate. for measures of abundance, due to standardization problems between vessel classes and gear types. Effort data resulting from trip interviews is not available for the Gulf of Maine. To increase its usefulness, effort data should reflect time on the bottom and/or area dredged on a per haul basis. Secondly, the collection of samples from the commercial fishery for size and age composition analysis is not adequate, particularly from the MidAtlantic area. Collection of this type of data presently relies heavily upon the voluntary cooperation of fishermen ("shuckers") in securing samples. This data is critical to an adequate estimation of standing stock and production. Finally, there are some problems with ageing scallops from areas where shell structures may be indecipherable due to abrasion. As a result, it may be difficult to determine age composition for analysis and comparison among scallop stocks.

Viewing scallop assessments as a whole it is clear that it is possible to evaluate yield per recruit in determining the length at first capture which will maximize yield. We have available for management purposes relative estimates of recruitment a year or two prior to entry into the fishery and relative stock abundance indices, both available from research vessel surveys. Unfortunately, there are no absolute estimates of current stock abundance or minimum spawning stock size, reliable early indicators of year class strength, apparent stock/ recruitment relationships or clear relationships among stocks to assist the assessment process.

3) It was generally agreed that the objectives were reasonable; however, various difficulties 
associated with implementing measures to achieve certain objectives were evident.

The objective to restore the adult stock components so as to minimize fluctuations in stock size due to variation in recruitment is useful only with a view toward the historical performance of the stock, the criteria for restoration and the time frame involved. With regard to the criteria for stock restoration, workshop participants were in agreement that restoration in terms of numbers alone was not sufficient to achieve objectives directed toward maximizing yield per recruit and minimizing the impact of variations in recruitment on stock biomass. Rather, stock restoration in terms of increasing the average age of scallops in the population, coupled with some minimum stock biomass constraint, better satisfied the intent of the adopted management objectives.

The objective to increase yield per recruit will tend to maximize yield from the scallop fishery, and in combination with quota restrictions serve to restore the stock. The workshop participants agreed that measures adopted to maximize yield-per-recruit should apply uniformly over the range of the resource; however, they noted that effective means for controlling length at first capture have not been developed for the sea scallop fishery.

However, major limitations were seen in implementing minimum size regulations. Shucking at sea makes it difficult to control minimum size because of the high variability in meat weight with respect to shell length. Research has indicated that there is no savings gear for scallops, and at present a practical means of mechanically culling the catch at sea has not been developed.

Control of fishing mortality with a view toward maintaining a minimum spawning stock size was suggested as having practical merit. The imposition of catch quotas consistent with a minimum spawning stock (by area) constraint serves to encourage a distribution of year classes within the stock and may satisfy the objective of maximizing net economic benefits if quotas are adjusted according to some optimal time path of exploitation. This is particularly important where one year class is expected to dominate the fishery. 
In this regard it seems that research directed toward improved assessment capabilities (commercial catch analysis, ageing, recruitment predictions, effort datal, and the implementation of management measures (i.e., minimum shell size to maximize $Y / R$ ) would best provide a basis for sound management in the near future."

Update - mid 1978

In a July 10 memorandum to both New England and MidAtlantic Councils, Spencer Apollonio, then Executive Director of the former. Council, updated the status of FMP development, refreshed the Council's memory on Plan objectives, commented on the workshop, and noted the Staff's developing Economic Impact Analysis. A Scallop FMP outline was also presented to give the council a feel for the Plan's contents.

Almost a year and a half had passed since implementation of the FCMA, and a Scallop Plan to take the place of ICNAF meat count and shell size regulations was still far from completion. Reasons for this long delay were a preoccupation with more pressing groundfish and sea herring management issues and a realization that scallop management objectives and strategies were not as clear-cut as originally envisioned.

Resource status and industry views

The Scallop Committee with Daniel Arnold (Executive Director Massachusetts Inshore Draggermen's Association and new Council member) as Chairman met in New Bedford with industry advisors and NEFC assessment scientists to acquire industry's views on management needs in the scallop fishery. The most recent assessment information and its implications for management and future of the fishery were also discussed.

A NEFC assessment scientist provided results of the 1978 U.S. and Canadian sea scallop surveys and landings (recent and historical). Some of this information had already been presented at an earlier september 25 NEFC briefing held for the New Bedford industry. Other data, particularly results of the 1978 surveys, were seen for the first time.

Importance of the strong 1972 year-class to fisheries in the South Channel (western portion of $5 \mathrm{Ze}$ ) and Mid-Atlantic regions were emphasized. This year-class dominated research vessel catches and commercial landings and was not expected to support the fishery for much longer. The 1973 and 1974 year-classes in all areas were judged to be fair to poor except on the Northern Edge and Northeast Peak of Georges Bank where these year-classes were good. The 1975 yearclass appeared to be poor in all areas except, again, for the Northern Edge and Northeast Peak where it was assessed to be good. This latter revelation (1975 year-class) was 
bad news for it had been hoped that the 1975 year-class would be good so that the existing high fishing effort in the Mid-Atlantic and South Channel could continue in the near future without a need to shift effort toward the U.S./Canada disputed area which included the Northeast Peak and Northern Edge. Some industry members were visably disturbed to discover that the "motherlode" existed only on the Northern Edge and Northeast Peak for it would mean that the future economic health of the industry would be linked to that area currently being contested with the Canadians. The 1976 and 1977 yearclass strengths were unknown since small scallops were not effectively retained in survey catches.

Status of the development of the sea Scallop Plan was given. It was stated that no management strategies had yet been developed by the Staff for the Council's consideration. In response to an industry question, "Why the immediate need for a Plan?", Spencer Apollonio noted:

1) Canada had stated that no joint management of scallop stocks could occur until the U.S. had a scallop plan. Therefore, the secretaries of Commerce and State were pressuring the Council to formulate a Plan as soon as possible;

2) the Council voted in early 1977 to develop a Plan, and time was passing;

3) the Mid-Atlantic Council wanted a Plan. It felt that "stock" abundance of scallops in their area could be stabilized if quick action was taken.

Daniel Arnold asked industry representatives to give their views on management needs in the scallop fishery. One fisherman stated that a meat size restriction and a prohibition of shell stocking (landing scallops in the shell rather than shucked) would be suitable. Another fisherman suggested a limitation on fishing days (perhaps eight fishing days with a mandatory five days at home between trips). Suggestions on gear restrictions (dredge ring sizes) and spawning area closures were also offered.

Few industry representatives realized that an optimum yield (or quota) had to be set. When asked to verify that regardless of the need for an $O Y$, the Council had to determine one, Mr. Apollonio stated that while oY had to be set, the FCMA did not specify that it could not be exceeded. He noted, however, that washington NMFS did not share his views. Some fishermen were disturbed at this revelation. No one wanted the problems occurring in the groundfish fishery to be repeated for scallops. 
On January 4, 1979 the Committee received a tentative time schedule for scallop Plan development. A final draft of the Plan was anticipated for May 1979 when the Council was expected to act on Committee recommendations and the public review process was to begin.

Council staff was working with the NEFC to develop a range of management strategies for Committee review, and it was decided by the Committee that these strategies should be reviewed with input from both the Mid-Atlantic and South Atlantic Councils. To insure that input, the Committee decided to ask a Mid-Atlantic Council member and industry advisor from that region (New York to Virginia) to participate in Committee meetings. Also, "all relevant papers were to be sent to the South Atlantic Council for its review".

Bio-economic analysis

A "Preliminary report on the bio-economic analysis in support of Atlantic Sea Scallop FMP Development" was presented to the Committee at its February 23 meeting. At the same time, Part one of the Plan - Statement of the Problem was presented for review.

The bio-economic analysis "demonstrated the nature and complexity of impact assessments of total allowable catch (TAC) strategies that the Council will have to consider". Impacts on prices, total revenues, U.S. consumption, imports, and employment, average vessel gross stock, crew shares and boat shares were evaluated. The analysis enabled a tracing over time of the impacts on stock abundance and harvesting costs of different multiple year quota strategies to determine the TAC causing the most beneficial impact.

Regarding various initial proposals for TAC's, the staff acknowledged that biological data limitations prevented an analysis of multiple year TAC's similar to the analysis done for the sea Herring Management Plan. Impacts could only be identified for a single year.

The staff suggested that a reduction of annual harvests from Georges Bank and the Mid-Atlantic from "recent high nonsustainable levels to historic average levels of exploitation" was most consistent with the council's objective of spreading catch out over time rather than to concentrate effort into a limited time period. According to the staff,

"In the Georges Bank resource $8,000 \mathrm{MT}$ reflects the average level of harvest over the past 20 years. Under the assumption that terms of the current draft U.S./Canadian Fisheries Agreement for Scallops will prevail, the U.S. share of the 
total scallop harvest on Georges Bank (26.4\%) is

2,100 MT. In the Mid-Atlantic an annual catch of

3,500 MT represents the average annual harvest

over a 15 year period during which two unusually

strong year-classes passed through the fishery."

With an aggregate 19.79 catch of $5,600 \mathrm{MT}(2,100+3,500$ MT) the staff predicted that average annual ex-vessel price would rise by $28 \%$; however, total gross revenues to the harvesting sectors were expected to drop from $\$ 79$ million in 1978 to $\$ 40$ million in 1979 (49\% decrease). At the same time with a 7,000 MT reduction in Canadian Georges Bank catch, U.S. imports from Canada were expected to fall by over $50 \%$. New England and Mid-Atlantic fleets were expected to experience a $46 \%$ and $53 \%$ drop in total gross revenues, respectively.

The Staff defined the amount of effort in the scallop fishery. They indicated that their review of the industry showed over 300 vessels participating in the scallop fishery. However, only a small percentage of these vessels showed heavy dependence on scallops as a source of revenue. Twentyfour vessels (dredges) operating year-round out of New Bedford accounted for $52 \%$ of the $1977 \mathrm{U} . \mathrm{S} .5 \mathrm{Z}$ catch of scallops and approximately 33\% of the U.S. Mid-Atlantic catch. For these vessels (assuming no new entries), the Staff's suggested initial TAC strategy was expected to cause a loss in the annual gross stock to the average vessel of over $\$ 400,000$ (40\%) compared to 1978. The net boat share was expected to fall by $\$ 130,000$ and annual crew share by approximately $\$ 21,000$. With new entries, returns to labor and capital were predicted to fall even further.

Assorted suggestions and a revelation

This depressing news prompted the Committee and advisors to discuss the need for limited entry into the scallop fishery - if a TAC was necessary - to prevent possible economic losses to vessels already in the fishery. It was decided that limited entry was not a stopgap to overfishing since the existing level of effort in the fishery was already high enough to catch scallops beyond any "sensible TAC" (e.g., 8,000 MT U.S. and Canada).

In lieu of a TAC and economic hardships it would probably impose, industry advisors suggested a management strategy for the council to consider. New Bedford advisors recommended limitations on scallops similar to self-imposed industry restrictions; i.e., a limitation on number of days of fishing per trip. New Bedford industry representatives felt their own "effort restrictions" combined with a few other controls on catch were sufficient to meet conservation goals set by the council. 
At the next Committee meeting held on March 12, MidAtlantic Council advisors' input, obtained at a Mid-Atlantic Advisory Subpanel meeting, was related. The most significant contribution of that Advisory subpanel was a revelation that a significant sea scallop fishery was prosecuted by North Carolina fishermen in areas off the South Atlantic coast. This bit of news and the need and desire of the Committee to acquire more information about that South Atlantic effort marked a turning point in the Committee's composition and a need for the Committee to widen its focus to include impacts of its future recommendations on sea scallop management over the scallop's range along the Atlantic coast. As shall be seen from following discussions, new South Atlantic Council and increased Mid-Atlantic Council inputs into Committee deliberations caused a great deal of consternation on the part of the southern New England sea scallop industry, notably the New Bedford industry.

Recommendations

The Committee decided to propose:

1) 1,000 lbs./man/trip; maximum of 11,000 1bs./trip;

2) trip limited to 8 days, 5 day layover; layover adjustments for shorter trips;

3) dredges limited to $13^{\prime}-15^{\prime}$ to a maximum of $26^{\prime}-30^{\prime}$ total;

4) ring size increased to $31 / 2$ " no later than 6 months after FMP implementation;

5) meat count regulation of 30 meats/lb. (roughly equivalent to a 4 year old scallop);

6) end of year break: sail before December 5, sail after January 22 .

Other recommended actions were:

1) a sea sampling/commercial observer program be established by NMFS for the New England and Mid-Atlantic regions to systematically monitor harvesting practices and status of stocks;

2) NOAA Counsel should be asked to comment on the legality of establishing crew limitations.

Lomestic OY is intended to be equivalent to expected level of catch achieved by fishing in accordance with regulations suggested in items $1-6$. Council Staff will evaluate level of catch which may be expected as a result of regulated fishing activity. 
These recommendations were presented to the Council at its March 14 and 15, 1979 meetings, but a decision on their acceptability was postponed until April meetings. This was to enable the committee to meet one more time to provide the South Atlantic Council and Mid-Atlantic Council with one last opportunity for review and input before a final New England Council decision. New Bedford scallop interests who were the prime movers of the six recommendations did not appreciate the delay. In the opinion of some New Bedford advisors, New Bedford had a long-standing, continuing interest in the sea scallop resource, as demonstrated by its history in the fishery and its self-imposed "conservation measures"; hence, desires of Mid-Atlantic and South

Atlantic scallop interests (primarily shell stockers) that entered the fishery only in "good times", should not be given great weight and influence on New England Council decisions.

\section{A three Council confab}

The next Committee meeting was held on May 7, The meeting's purpose was for the three Council-Committee to "propose or endorse management measures based upon their best understanding of the status of the resource, sensitive to the regional needs of the sea scallop industry." Discussion covered a wide range of topics.

Council staff presented their preliminary analysis of the proposed 11,000 lbs. per man per trip limit to determine if it would be restrictive. Results suggested a $20 \%$ decrease in dredge catch although new entries would probably prevent any decrease in total catch by the fleet.

It was related by the Chairman that approximately 150 vessels (one-third shell stockers) were fishing from New Jersey, Virginia and North Carolina ports. A North Carolina representative stated that 69 vessels from North Carolina landed scallops in 1978 with approximately $60 \%$ being shell stockers. Forty-four Virginia vessels landed scallops in 1979. Consequently, it was clear to the Committee, especially New England representatives, that both the amount and types of effort in the Mid-Atlantic and South Atlantic regions needed to be addressed in greater detail. For example, the large amount of shell stocking was in conflict with one of the Plan's objectives--to enhance yield per recruitment (to avoid harvesting small scallops). Shell stockers fishing with nets caught all sized scallops and brought them to port for shucking and processing. Need for controls on this activity was apparent: however, the most appropriate and feasible kinds of controls and their impacts were not clear.

A representative of shell stockers noted that a minimum shell size would be required to prevent landing of small 
scallops. However, a minimum size would force culling of the catch while at sea and a need for at least one more crew member causing a decrease in crew share. Also, mesh size would have to be adjusted to allow escapement of smaller scallops, yet no one knew selectivity of nets for different sized scallops. Moreover, culling in warm weather was expected to increase mortality of scallops sorted on deck so undersized scallops returned to the sea would be dead.

Opinions differed, as expected, between scallop fishermen advisors who used dredges and those who used nets. Those in favor of dredging felt that shell stocking should be prohibited especially since it was not a traditional fishery and very small scallops were caught to the detriment of the resource. In retort, netters noted the great market demand for small scallops, and netters were able to provide them. It was claimed that netters could fish where dredges could not, and this opened new fishing grounds. Also, it was claimed that any outlawing of netters would be disastrous to the Mid-Atlantic and South Atlantic scallop industry.

Ensuing discussions centered on meat count as a conservation measure. New Bedford interests favored a 30 meat count with the number of days fishing restriction, and considered this strategy to be an adequate substitute for an $O Y$ or quota. On the other hand, Mid-Atlantic scallop interests were opposed to any limitation on days fished, wanted some form of OY or TAC (such as OY equal to 1978 catch), and preferred a 40 meat count restriction since it would allow landing of smaller scallops and was comparable with the canadian fishery's 40 meat count restriction (with 10\% tolerance). These differences in opinions led to a discussion on the possibility of establishing separate Mid-Atlantic and New England management areas with different management strategies for each area. No conclusion was reached.

The Committee's choice of meat count could not be finalized although, in the Chairman's opinion, the Committee appeared to favor the 40 meat count with a corresponding shell size restriction. The chairman stated further that if a 40 meat count was the Committee's final choice, that count needed to be linked with a strong recommendation to the secretary of Commerce that she negotiate with Canadians to eventually reduce the meat count for both countries to 30 meats per pound.

The meeting ended with a South Atlantic Council representative suggesting a great deal of additional staff work. His suggestion raised the hackles of some New England scallop industry representatives who felt the suggestion would cause a major delay in the scallop Plan's completion and implementation to the detriment of the resource. Additionally, the staff felt that before it began new 
analyses and data gathering efforts, the Committee should first take a position with regard to the "Statement of the Problem" and the "Preliminary Bio-Economic Analysis" written by the staff in support of the PIan's development. These documents had been distributed to the committee in February and March. The Staff was looking for guidance from the Committee. This guidance was not provided.

At May 16 and 17, 1979 Council meetings, the Council was apprised of the divergent New England and Mid-Atlantic views. Daniel Arnold emphasized that the Committee was obligated to solicit all information available to insure views of all geographic areas. He noted that strategies would be discussed in greater detail in July.

\section{A bit of irony}

The Mid-Atlantic Council expressed its displeasure over the slow progress of Plan development. This displeasure sparked some negative comments from New England Council members at June 27 and 28, 1979 Council meetings. The New England Council had gone to great lengths to insure MidAtlantic, and South Atlantic, input for the Plan's development. This action was responsible for much of this delay. As stated by Harvey Michelson, "It would seem to me that this Council has the responsibility for formulating a Scallop plan. If this Council or the Scallop Committee had gone ahead and formulated its position on what the Plan should be and then submitted it to the Mid-Atlantic we would be much further ahead. The lead group should make its position known, and take it from there".

Not everyone shared this view, however. The committee Chairman in particular suggested that the council ask the Secretary of Commerce to give both council's joint management authority for sea scallops, and he made a motion to carry out this intent. However, this motion was later withdrawn after the Council's collective sentiments became clear.

A majority of Council members were unwilling to relinquish any management authority for two reasons. First, the issue of sea scallop management was extremely sensitive, particularly to New Bedford interests. This had been brought about by the proposed U.S. /Canadian Treaty and provisions thereof with regard to scallop percent shares and management authority. To delegate any more scallop management authority away from the New England Council was considered unpalatable by many. Secondly, the Mid-Atlantic Council had yet to properly address the New England Council's concerns over surf clam management. The Mid-Atlantic Council had lead authority over the entire surf clam resource off the Atlantic coast, and the New England Council was piqued over the continued failure of the Mid-Atlantic Council to adequately address concerns and needs of the New England surf clam fishing 
interests. While this latter reason could have been considered vindictive, it nevertheless was understandable, particularly considering the history of conflict between both councils on surf clam management. A moratorium on entry into the surf clam fishery, which effectively stymied any development of a New England fishery, had been especially contentious, and MidAtlantic recommendations for plan amendments did not satisfy New England interests.

Definition of issues and management unit

The Scallop Committee met on July 10 in Philadelphia to finally address the Staff's "Draft Part I - Scallop FMP, Statement of the Problem". Management issues approved by the Committee were:

"In the absence of harvesting and/or effort restrictions in the scallop fishery, the domestic catch of scallops in 1979 is expected to be equal to or greater than the 1978 catch. This expectation is based on the assumption of continued high ex-vessel prices suggested by strong consumer demand. This will support continued high or increasing effort levels.

The resource outlook presented earlier indicated that recent years harvest levels cannot continue in 1979 without a decline in stock abundance and a reduction in catch rates. Given that this is the prospect and that future recruitment is uncertain a main problem for management is to determine the preferred time path for harvesting the presently available scallop biomass. How much of the current stock should be harvested in 1979 and how much should be set aside for 1980 , etc?

A decision to abstain from or to restrict harvesting of scallops is an investment decision. Like other investment decisions, it requires determination of an expected return within some defined planning period. As most fisheries the growth and mortality parameters of the stocks as well as current and future prices and costs determine return on investment. Direct and indirect effects on employment are likely to be additional considerations relative to an assessment of a social return on the exploitation of resources. Future streams of benefits and costs are impacted by future levels of resource utilization and by the particular sets of management regulations enforced in future years. Management strategies, therefore, have to be viewed as encompassing a time span longer than one year. It follows that annual "optimum yields" have to be determined for multiple years, rather than a single 
year, recognizing that future "optimum yields" will have to be revised as our perception of the biological and economic decisions environment improves, and as our objectives for management change.

Review of the industry structure has pointed to a pattern of historical dependency of various fleet sectors on specific resource components. The imposition of annual TACs for such resource components might initiate shifts in spatial allocation of fishing effort of various fleet sectors. A major issue to be addressed by the Councils is, therefore, whether the distribution of harvests among users is to be left to the free market forces or to the introduction of explicit systems for distributing TACs among user-groups. In this latter regard, it is recognized that vessel and gear restrictions, definition of fishing areas, and fishing periods are regulatory measures with implications for the distribution of harvests among user-groups.

A third management issue involves the decision of enforcement of the overall species quota as well as season or vessel group quotas if such allocations are made. This issue has its roots in the pressures for exceeding the imposed TACs which must be anticipated in periods when the expected domestic catch in the absence of regulations exceeds the total catch limitation imposed.

Finally the issue of limiting entry into the fishery shall as a matter of Council-determined procedure be considered in the FMP for scallops. The immediate need to address this issue in this Plan emerges from the concern over the impact that the expansion of fleet size and effort observed in recent years will have on the council's ability to effectively manage the fishery and in particular to enforce overall catch limitations. More fundamentally, however, the issue of access control bears directly on the achievement of management objectives, i.e. what are the impacts of continued free entry into the fishery on the overall benefit to users of the resource?"

The Committee also decided the management unit:

"The fishery resource addressed by this management plan encompasses the population of sea scallops, Placopecten magellanicus, that occur along the continental shelf of the northwest Atlantic within the boundaries of the FCZ. The resource is found 
found from the Northeast Peak of George's Bank westward to the Great South Channel and along the continental shelf of the Mid-Atlantic. It is recognized that commercial quantities of sea scallops also occur within the territorial waters of the state of Maine and of Canada. These scallop resources are outside the authority of this FMP, and for management purposes may be assumed to interact with those under the jurisdiction of the FMP at the market level only.

Three resource components within the FCZ may be generally defined. These consist of the northern edge and northeast peak of George's Bank, the Great South Channel, and the Mid-Atlantic Bight. Although there is little biological evidence, particularly reproductive, that could serve as a basis for stock separation within the bounds of the resource described, the three resource components will be treated as independent stocks for management purposes based upon their geographic separation, historic trends in recruitment, and levels of production, and proximity to user groups.

It is recognized that management authority over the George's Bank sea scallop resource is an issue currently being resolved between the U.S. and Canada. Pending ratification of the draft U.S./Canadian Atlantic Fisheries Agreement, this FMP will be generated under the assumption that the negotiated terms of access and entitlement will stand."

August 1 and 2, 1979 Council meetings marked the acceptance of the "Statement of the Problem" part of the FMP. It was related that the Mid-Atlantic Council also concurred with the "Statement" at its July meetings. The Mid-Atlantic Council also accepted the New England Council's timetable for the Plan's development which indicated an expected November completion date for the Draft Plan.

Additionally, a July 31 letter (received by the New England Council on August 3) to the New England Council from the Mid-Atlantic Council indicated that Council's request to the Secretary of Commerce that she "declare the scallop fishery a conditional fishery in the Mid-Atlantic region, if not throughout its entire range." A conditional fishery designation for scallops would have caused NMFS to restrict use of financial assistance programs to prevent additional vessels from entering the fishery. Mid-Atlantic concerns over the scallop resource and fishery were mounting and that council had gone so far as to state it would prepare its own Plan if the New England Council did not speed up development of its 
Plan. The Mid-Atlantic Council later backed away from this position after it was led to believe that November was the expected Draft completion date. However, the request to make scallops a conditional fishery still stood firm.

Strategies develop

In October, progress was made on strategies to achieve the Council's Plan objectives. Council staff, with assistance from NMFS Staff, identified a range of strategies that could be pursued. However, before a detailed staff analysis of biological and economic impacts of each of its proposed strategies could be performed, Committee policy decision's had to be made. Three issues were:

1) desirability, of quotas in New England and MidAtlantic areas;

2) establishment of regional shares of quotas for each geographic area:

3) limited entry

These policies were discussed at an October 12 Committee meeting which began on a sour note. Mid-Atlantic Council members present felt they could not make any determination of management strategies for the Mid-Atlantic Council. This was ironic to some Committee members since the Mid-Atlantic Council was on record as wanting a scallop plan in place as soon as possible, yet its representatives were not willing to express any policy preferences for the Mid-Atlantic.

The question of TAC's for the scallop resource was debated and it was decided that the staff would analyze a number of strategies to result in biologically justifiable and non-biologically justifiable levels of allowable catch. The Committee was to then review these catch levels to decide if it wished to opt for a TAC or an expected catch (implied TAC). The difference between these two classifications was not completely clear; however, as explained by the staff, a TAC was a cap which could not be exceeded while an expected catch (implied TAC) could be exceeded if, for example, scallops were more abundant than originally assessed.

The meeting concluded with further requests for staff analyses of regional shares and no regional shares of the resource and general aspects of management proposals offered by New Bedford scallop interests in March. The Committee voted to formally adopt a 30 meat count management measure and again suggested that the secretary of commerce 
negotiate with the Canadians to achieve a complimentary meat count. Significantly it also voted to have no overall catch limitation on the sea scallop fishery; i.e., it decided to adopt an implied TAC. OY was to be the expected level of catch resulting from fishing under the eventual management system which was to include the 30 meat count. count.

The Committee shied away from TAC's since TAC's were bound to have significant adverse impacts on the U.S. fishery. For example, assuming the council eventually decided to adopt a 9,000 MT quota for Georqe's Bank (reasonable estimate of MSY - mean annual landings since 1960) and the U.S./Canadian Fisheries Treaty was eventually ratified giving the U.S. only a 26.65\% share of George's Bank scallops, the U.S. scallop TAC under the Council Plan would only be approximately 2,400 MT. With the scientists' prediction that abundance of scallops was decreasing everywhere except for the Northern Edge and Northeast Peak of George's Bank, the hesitancy of the Committee to use quotas was understandable.

\section{November discussions}

Staff analyses were revealed at a November 19 Committee meeting. Since a strong relationship between fishing effort (standard U.S. days fished) and fishing mortality was found to exist in the Georges Bank sea scallop fishery, the Staff used effort data to determine long-term sustainable levels of effort which would not have unacceptable biological impacts. The Staff equated historical average effort levels (U.S. and Canadian) of 2,320 days fished to be acceptable biological impact. The historical maximum (4,226 days) was equated to marginally acceptable biological impact with higher levels being unacceptable.

Under all examined scenarios involving different New England and Mid-Atlantic shares of the Georges Bank and Southern New England resource, management solely by meat count was predicted to cause an unacceptable biological impact. Only when days fished was reduced by $50 \%$ or greater did the biological impact become acceptable. This "needed" overall cut in fishing effort combined with the proposed U.S./Canadian Fisheries Treaty U.S. percent share caused the Committee to drift farther from TAC or effort management.

While the Committee was divorcing itself from quota or effort management, some industry advisors were leaning the other way. Advisors were noting decreases in average catches of scallop per vessel, an absence of small scallops 
on the fishing grounds (needed to sustain future high catches and effort), and increased effort on George 's Bank. They felt a need for more restrictions than just a 30 meat count. Indeed, Guy Marchesseault of the Council staff, added that a 30 meat count in 1980 would not limit the New England scallop fishery since the average size of landed scallops (primarily 1972 year-class) would result in an even smaller count (e.g. 20 count). Note: the larger the meat or scallop, the smaller the count. Also, as it was later learned from a NEFC assessment, the 1979 NEFC scallop survey indicated that "as a result of heavy fishing pressure applied over the last few years, the 1972 year-class no longer held its position of prominence, and abundance has subsequently decreased in all areas. As in 1978, there was no evidence of improved recruitment which might have alleviated the trend of decreasing abundance."

The Mid-Atlantic viewpoint was provided by Barbara Stevenson. She stated that the Mid-Atlantic Council would accept a 30 meat count, was opposed to separate management regimes, and wanted a TAC equal to historical high landings. A South-Atlantic Council opinion was given by Michael street. In contrast, he stated the South-Atlantic Council would support some effort controls including possible limited entry, wanted separate management regimes for each stock, and opposed a 30 meat count. As stated above, the committee did not savor effort limitations; however, somewhat incongruously, it decided to accept a staff proposal that a reduction in fishing effort was needed and that the Staff and Committee should attempt to reach an acceptable reduction in effort throughout the entire fishery. The Committee did not bend on its position regarding quotas. The Committee agreed "that the management system would establish measures aimed at achieving acceptable levels of economic benefits while at the same time reflecting biologically acceptable levels of resource exploitation. As such, the expected level of catch resulting from fishing under a management system would define the OY, although this level would not serve as a measure constraining overall catch." Mid-Atlantic Council representatives did not support this position.

\section{Divergent opinions}

At December 12 and 13, 1979, Council meetings, divergent opinions of the three Councils were related. According to the Committee Chairman, Daniel Arnold, "The Committee is currently facing complex political and resource problems which must be resolved before the FMP can be finalized. There are representatives from the Mid-Atlantic and South Atlantic Councils representing significant scallop interests who are advocating management systems which are not in harmony with the New England industry's articulated needs and preferences". Council member Harvey Mickelson was outspoken 
on this issue. His views were, as described by Barlow (Maine Commercial Fisheries, January 1980):

"Stating that delays in the preparation of the Scallop FMP had been caused by 'the unnecessary introduction of comment, directions and requirements of people who are not voting and not responsible for this Plan', Harvey Michelson again expressed his frustration with the time-consuming process of FMP development. As he further elaborated on the situation from his perspective, he described a situation in which the work of the scallop Oversight Committee was being hampered by efforts to accomodate the interests of scallopers from the Mid-Atlantic and South Ätlantic areas. Based on lead Council status conferred on the New England Council by the Secretary of Commerce and the request by the New England sector of the industry to get a plan in place, Michelson believed that the proper procedure to follow was for the scallop Committee and the New England Council to prepare the Plan and then 'let the other Councils do what they may after we have done our work'."

Daniel Arnold noted that the Committee was to meet before the end of the year to hopefully agree on means of reducing fishing effort and also to discuss an industry suggestion of a meeting between Canadian scallop industry representatives and government officials, U.S. industry representatives, and Council members "to explore the possibility of joint agreement on matters relating to sea scallop management."

Strategies are adopted

On December 20, 1979, the Committee met again and formally adopted a management program for sea scallops. Three Committee members, other New England Council representatives, South Atlantic and Mid-Atlantic Council members, industry advisors, and Staffs of NEFC, the Regional Office and the council were in attendance.

In spite of another South Atlantic Council request that the Committee reverse its position on the 30 meat count and increase it to 40 meats per pound, the Committee reaffirmed its October vote to proceed with 30. The feeling was that with a 40 meat count "more stringent effort controls may be necessary."

The Committee agreed that vessels should be required to obtain a permit or license (with a minimum amount before which none would be needed); vessels had to furnish NMFS with specific statistical data; designation of the fishery as "conditional" should not be considered as part of the plan; and, the Council should commit itself to formulate some 
additional measures of effort control (no deadline was set). Mid-Atlantic and South Atlantic representatives were asked to acquire their Council's views on these issues as soon as possible.

Other questions raised but not answered were:

1) Should there be regional allocations or shares of the resource?

2) Should the Council adopt a limited entry program? Council staff recommended a limit on the number of vessels which coula participate in the scallop fishery.

The Committee was also reminded that:

1) it had decided to recommend that the Plan have an "implied" OY;

2) the relationship of a 30 meat count to Canadian scallop regulations and imports of Canadian-caught scallops into the U.S. needed to be addressed;

3) the Committee should look to NMFS for a complete explanation of possible impacts of declaring the scallop fishery "conditional". Council staff recommended this declaration in order to discourage new investment in sea scallop vessels.

The Committee had been guided in part by conclusions drawn by the staff in its analyses of sea scallop management strategies. Those conclusions were:

1) The current levels of effort in the sea scallop fishery, if maintained, can be expected to result in a lower average level of long-term production from the resource than would be expected at lower average levels of applied effort.

2) The recent high levels of effort in the sea scallop fishery substantially increase the level of biological risk to the resource. This relatively high level of risk translates into a) wide fluctuations in abundance, b) increased chance of recruitment failure, and c) unexpected or unpredictable behavior in stock dynamics.

For any or all of these reasons, increased risk may negatively impact on the resource's ability to support an economically viable fishery in the future. 
3) Historically, effort has been directed away from the fishery as abundance has declined. Thus, despite the record, high ex-vessel price levels of recent years, it is expected that there will be a net reduction in fishing effort because of substantially decreased abundance over the next several years. However, the current and forecasted high prices can be expected to slow the rate of exit relative to historic observations.

4) At this time, given the conclusions in (3), it cannot be scientifically demonstrated that relatively modest reductions in effort (to 1978 levels for example), imposed as management measures within the FMP, would result in any measurable biological or economic benefits in the future.

5) In the absence of a management system controlling effort through 1980 , it is forecast that key dredge vessels participating in the fishery will experience a reduction in real income during 1980, and this trend is expected to be maintained through 1981.

Results of the December Committee meeting and an informal U.S./Canadian industry meeting were related at January 16 and 17, 1980, Council meetings. According to Dan Arnold,

"We did vote on three items. First a 30 meat count, second the requirement that any vessel must obtain a permit to participate in the scallop fishery, and third, that there be some recordkeeping. There was a lot of discussion on the general subject of effort control. This has been a great problem. The staff felt there was insufficient data at this time to design any kind of effort control in the plan. We settled on a statement that there would be effort control. As the data base improves we can develop an effort control system that will fit the fishery. The Mid-Atlantic representatives took this package back to the Mid-Atlantic Council and the first three items they agreed to. The fourth item of effort control they have problems with. One thing was that we said we would have an effort control system in place by a certain date, without definition of what the effort control system would be. They felt they could not agree with that. I feel we are pretty close. We need some proper lanquaqe, before that fourth itẹm will be included.

About a week ago I accompanied Mr. Costakes and Mr. Enoksen to Halifax, N.S. for a discussion with the 
Halifax Scallop Fishery members, and informed them of our intent to have a 30 meat count. They were not too receptive. We hoped we could get agreement without going through the governmental process to get this. Rejection means we will have to go through the Secretary of Commerce to get prohibition on Canadian scallops larger than a 30 meat count. Strong feeling that we want to prevent small scallops from coming across the border. I do not know at this time if we should recommend that. (see newspaper account describing Canadian 1979 fishery and a fishermen's viewpoint on U.S. effort)

Council members raised three issues was the 30 meat count appropriate for Gulf of Maine scallops; why did the Committee decide not to declare the fishery "conditional"; and, when would a final decision be made on the need for and kinds of effort controls? Regarding the first question. the Committee was charged to look at the Gulf of Maine scallops and to return with recommendations at a later date. On the need for a "conditional fishery" designation, it was related that the cons simply outweighed the pros and the Regional Director felt that the designation, if wished by the Council, should not be an integral part of the FMP. With respect to effort control, Daniel Arnold stated:

"We have expressed in Committee that this item is not dead. In fact, we have every intention of continuing the investigation into effort control. It is our intention that, at some time in the future, an effort control system would be outlined. developed, and included in the Plan. It may possibly be a future plan amendment."

On a nine to four vote the Council approved the 30 meat per pound restriction, the need for vessel permits, and the requirement that all vessels had to provide NMFS with specific statistical data.

\section{A significant meeting}

To provide operating guidelines for determination of compliance with the 30 meat count restriction, the committee met on March 6, 1980, and discussed a series of options provided by the staff. The Council unanimously approved a strategy whereby an average meat count of 10 one-pound-bag samples drawn randomly had to be less than or equal to 30 meats per pound and that no single one-pound sample could exceed a meat count of 40 . The latter stipulation was to discourage fishing predominantly on small scallops.

The committee also decided to include in the draft FMP two options for public hearing comment on a minimum shell size restriction - either a minimum size of 3. $4^{\prime \prime}$ with some percent tolerance or an average shell size of approximately $3.5^{\prime \prime}$. 


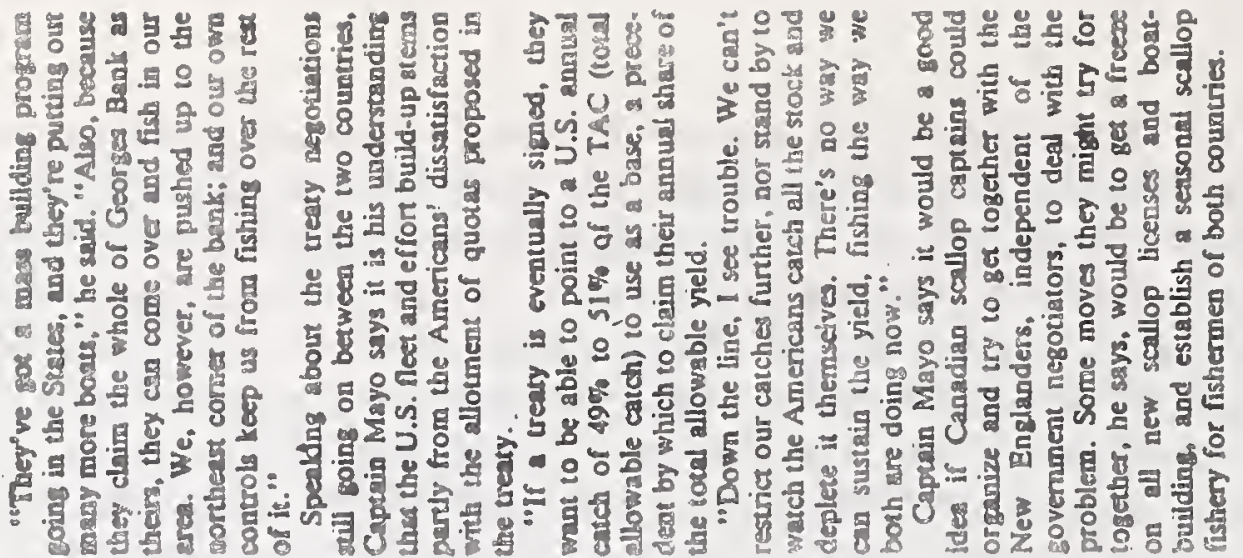

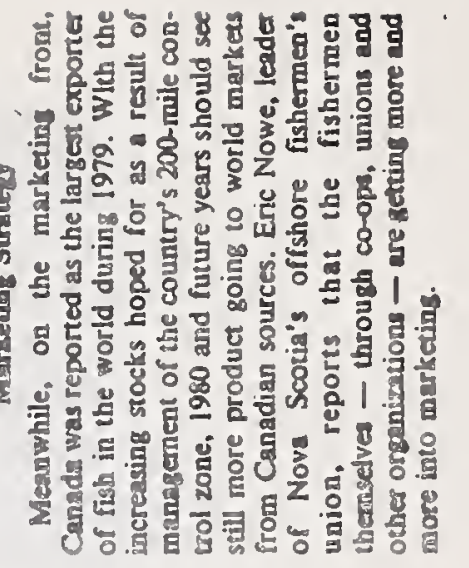

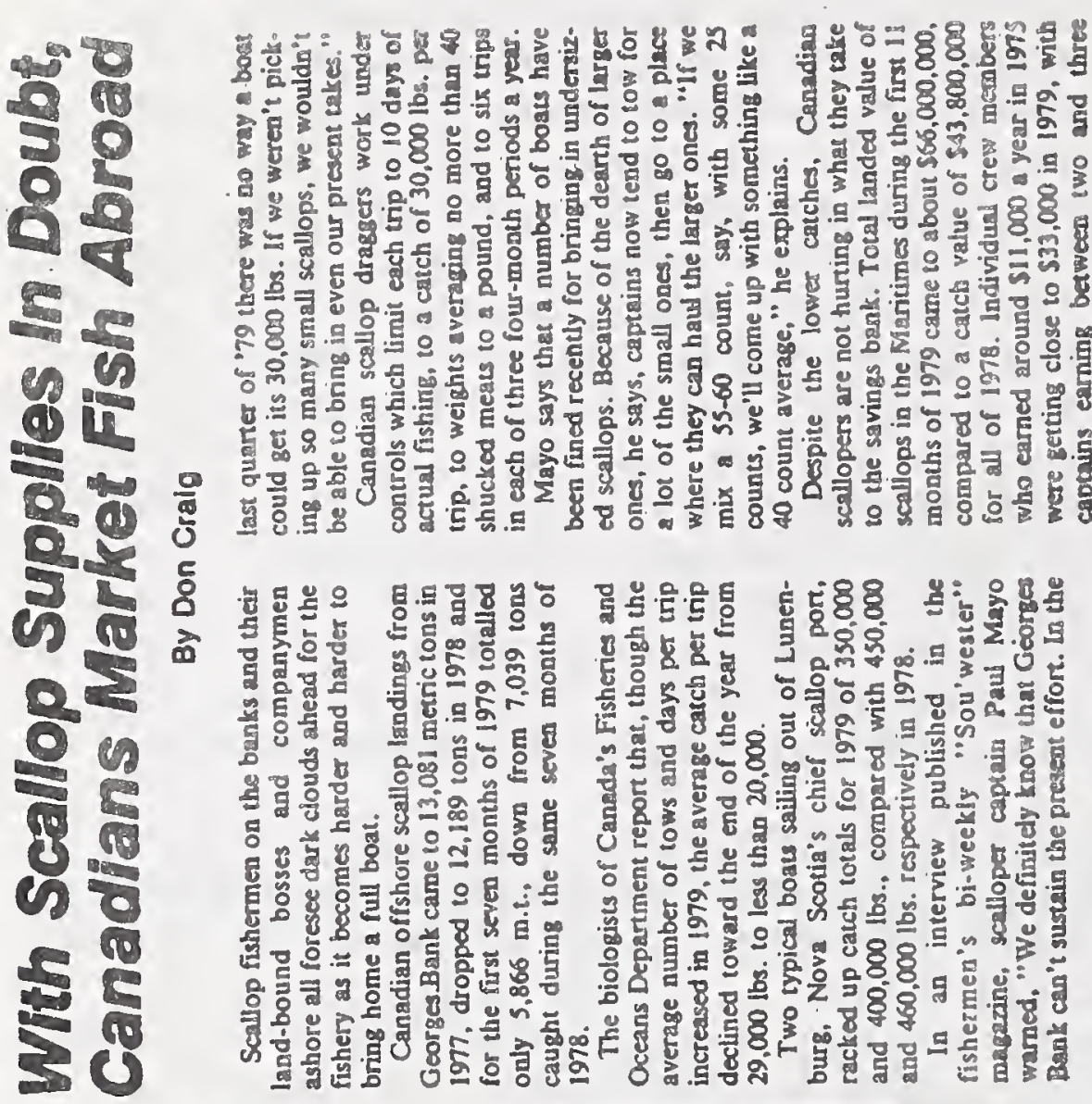
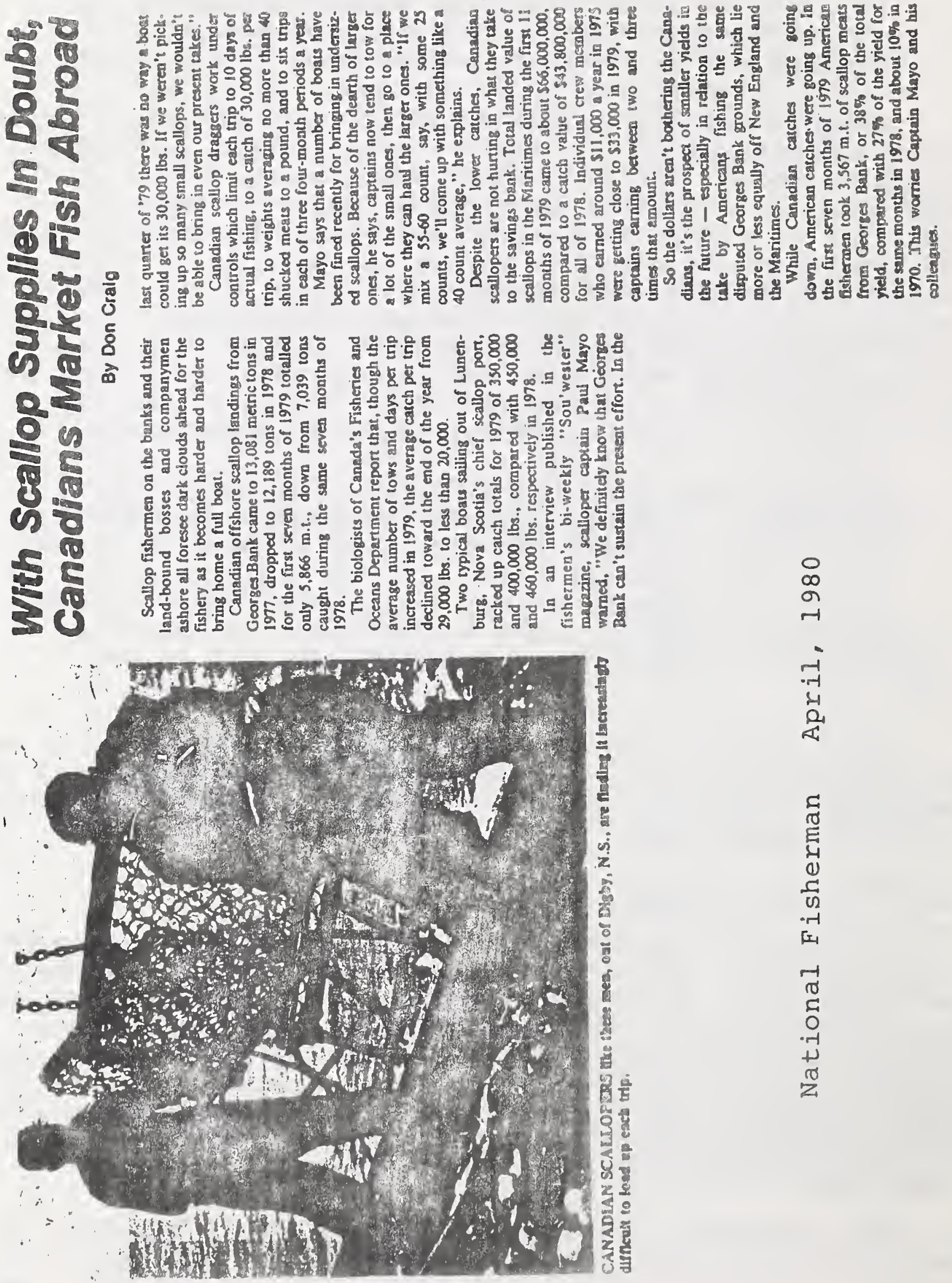

0
$\infty$
0
-1
-1
-1
-1
0
0
2

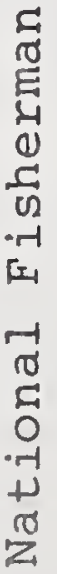


NEFC scientists had noted that overall for Georges Bank and the Mid-Atlantic a 30 meat per pound scallop equalled approximately $3.9^{\circ}$ with a lower $95 \%$ confidence interval of approximately 3.4"; i.e. it was quite safe to assume that a 30 meat count scallop would seldom have a shell size less than $3.4 "$.

Unfortunately for the Committee, their best laid plans were to be disrupted by a problem presented by Gulf of Maine scallops. According to Maine industry representatives and a Maine DMR scientist, the Maine sea scallop resource exhibited slower growth rates than scallops from other areas. This belief was the primary basis for an argument to exempt the developing Maine.FCZ scallop fishery from the meat count measure. A Council staff member, Guy Marchesseault; however, countered that "available evidence indicated that the terminal size of Maine scallops was well in excess of a 30 meat count and therefore the measure would not be discriminatory ${ }^{81}$.

The meeting ended with a Committee request that Maine collect biological data on the Gulf of Maine FCz resource to help resolve the question of a need for a possible Gulf of Maine exemption, and with a discussion on kinds of data required from permit holders.

A projected timetable

At March 25 and 26, 1980, meetings it was noted that a completed draft Plan was expected for April meetings with tentative June hearings and a July submission of the Plan to washington. The Plan was already twelve months behind schedule and some lamented this delay because small scallops were being landed especially by shell stockers operating in the Gulf of Maine. Mid-Atlantic vessels, in particular, had switched to more northern ports due to an extremely poor fishery in the MidAtlantic area. Of note, efforts of these and local vessels prompted the State of Massachusetts to enact a $3^{\prime \prime}$ minimum shell size with a $10 \%$ tolerance (same as existing Maine size) to prevent shellstocking of small scallops into Massachusetts ports such as Gloucester. This practice had increased due to availability of small scallops in the Gulf of Maine and was frowned upon by most Massachusetts scallop fishermen who wanted the small scallops to reach a size where they would produce a greater yield.

Timetable revision

The timetable had to be revised: i.e. the plan would not be ready for Council review until the end of May, and this revision prompted at April 30/May 1 Council meetings discussion on the slowness of the Plan's development. Daniel Arnold stated, "A number of times I have inquired as to how the work has been going, and there have been continuing emergency priorities on groundfish that set us back. I know 
I have never insisted that scallops be put ahead.' I am distressed that there have to be priorities. I feel that perhaps I am getting criticism because the Scallop plan has not progressed fast enough." Douglas Marshall, Council Executive Director, noted, "There has been a lot of pressure to get some sort of document to NMFS in Washington, and there may be some concern on the part of some council members that we should not proceed quite as fast".

These comments typified contrasting views of many council members; i.e., some wanted to complete the long overdue Plan immediately and some wanted to spend more time on its devel-. opment to insure its thoroughness.

State of Maine objections

On May 15, the Scallop Committee received a memorandum from Spencer Apollonio, Commissioner of Maine DMR, describing the newly developed offshore Gulf of Maine sea scallop fishery (see memorandum and newspaper article), and recommending that Maine's exisiting 3" minimum size limit be adopted for the Gulf of Maine scallops. He cited economic reasons for a 3" Gulf of Maine restriction and stated rationale for his belief that proposed Council regulations for the Gulf of Maine offshore stock were not justified. He began a still continuing state of Maine resistance to application of the proposed Council regulation for the Gulf of Maine (see July 16 memorandum).

Reaffirmation

On May 20, 1980, the Scallop Committee reaffirmed its position that there be "no management induced regional shares to the scallop resource components" meaning that the FMP "would not attempt to preserve current or traditional regional fishing practices of the scallop industries". The committee also reaffirmed the requirement that all vessels "which take and land sea scallops in any quantity need a permit" and decided that the permit was to be completely separate from enforcement; $i . e .$, a permit should not be forfeitted for violations of sea scallop regulations.

\section{At May 28 and 29, 1980, Council meetings the full}

Council unanimously approved the "no regional shares" and "a need for a permit" part of the Committee's recommendations; however, the issue of permit revocation was not as easily resolved. After length debate, the Council reversed the Committee's decision thus making it clear in the FMP that violators could lose their permits. A statement by Philip Coates, Director of Massachusetts Division of Marine Fisheries, reflected the view leading to this latter vote. That statement was ".....fishermen have always operated with the understanding that their permit is subject to revocation. Establishing a provision whereby under no circumstances would a permit be revoked is unacceptable from my standpoint." 
果

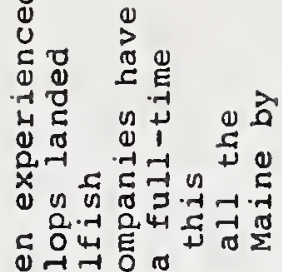
政

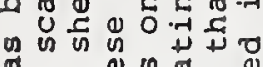
政

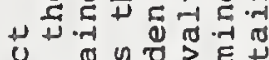
ond

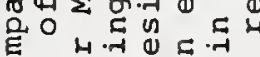

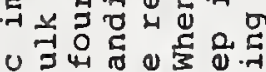

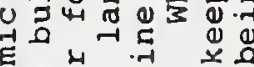

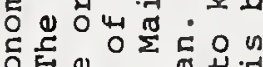
of

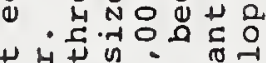
落 政

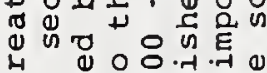
sog.

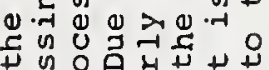

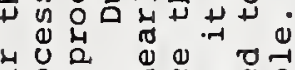

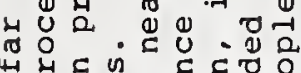

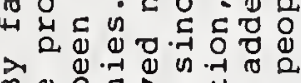

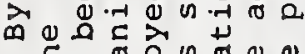

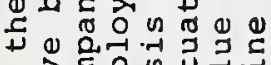

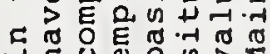

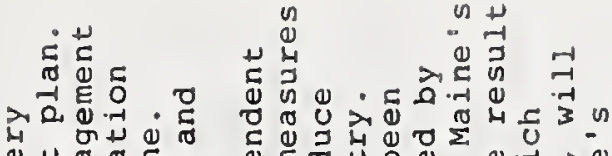

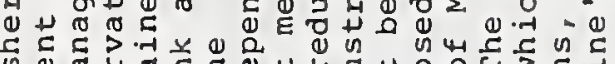

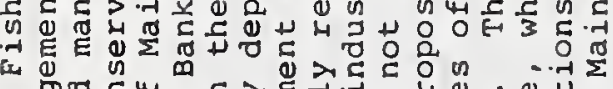

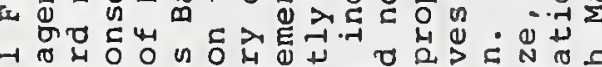
To

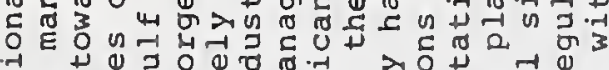

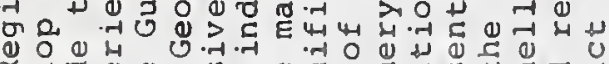
व

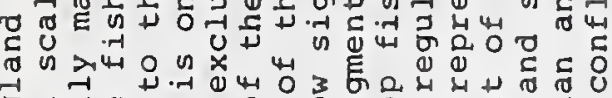

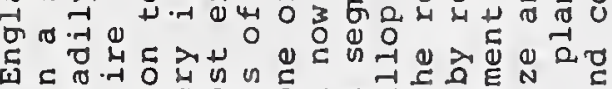
फ

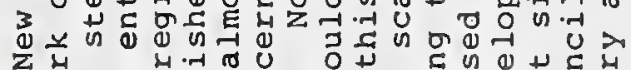

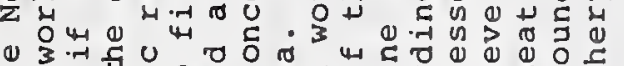
至

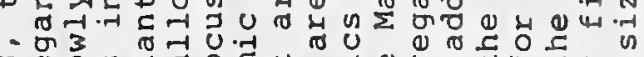

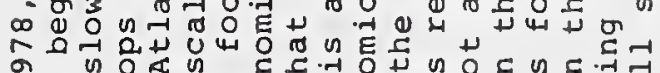

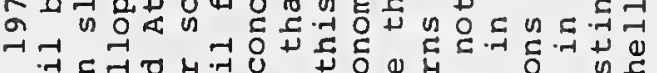

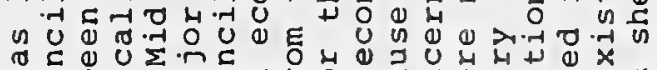
r

E a 要 $\begin{array}{llll} & \\ 0 & & \\ 0\end{array}$ 苟

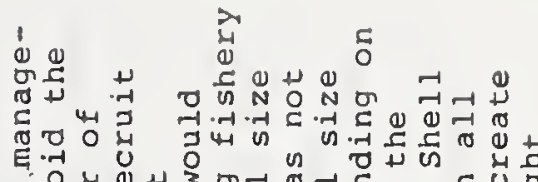
ه

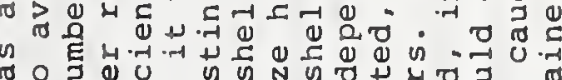
H

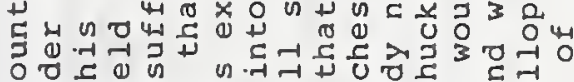

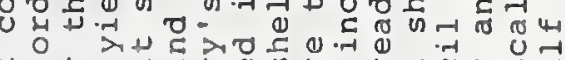

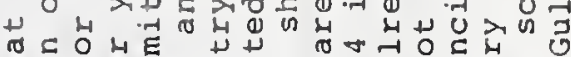

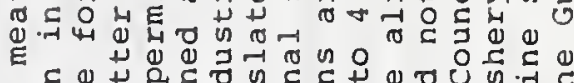
E

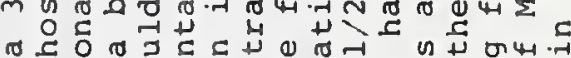

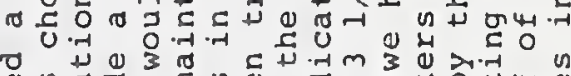

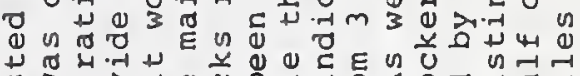

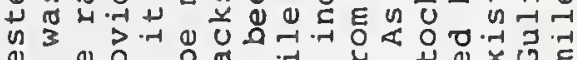

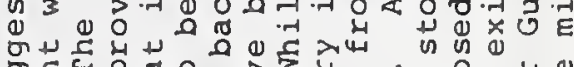

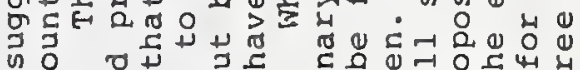

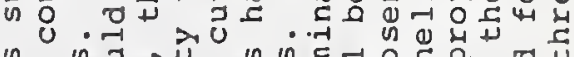

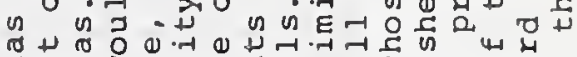

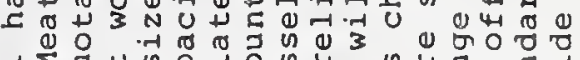

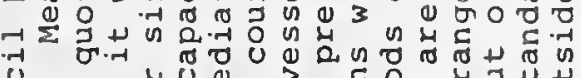

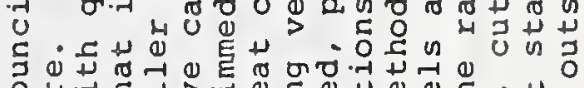

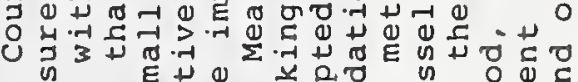

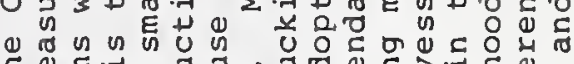
है 귱류

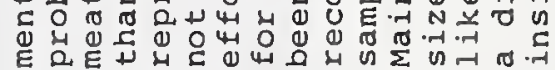

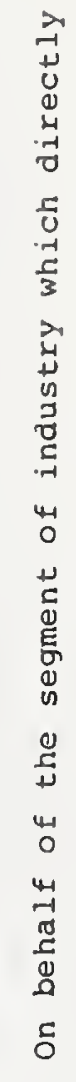

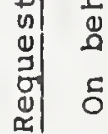

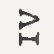

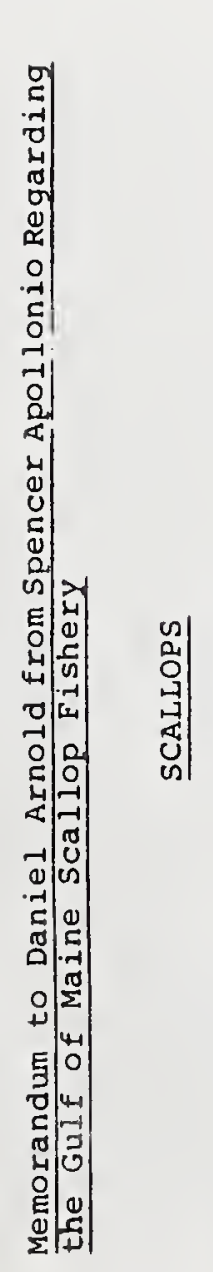

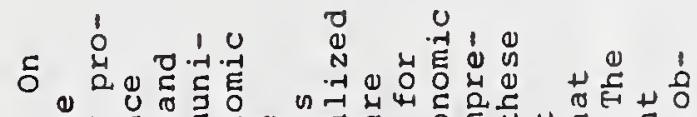

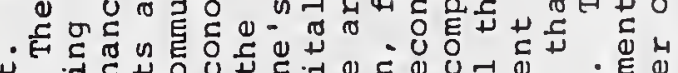
ᄃ

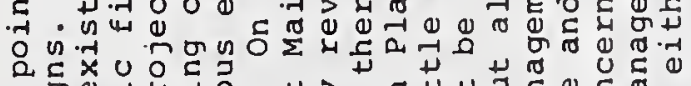

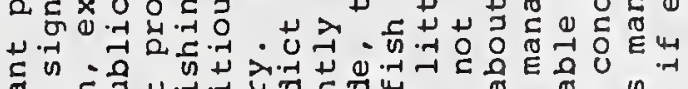
๘

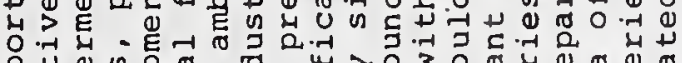

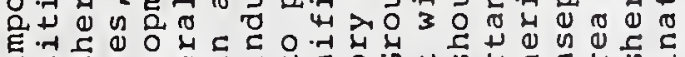
Eี ह

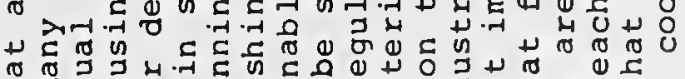

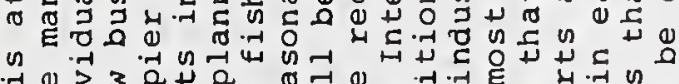

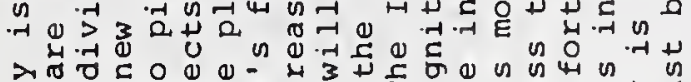
出

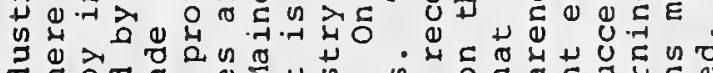

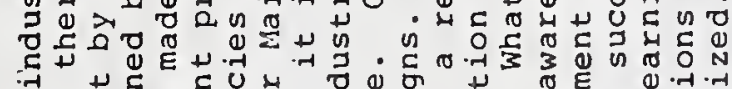
ब

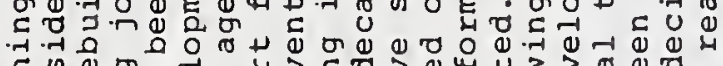

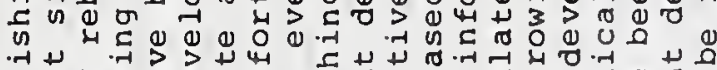

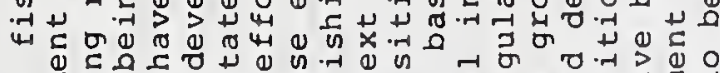
वَj

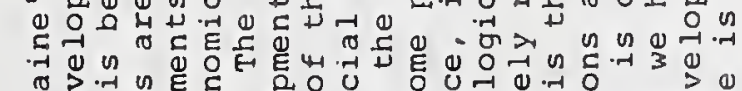

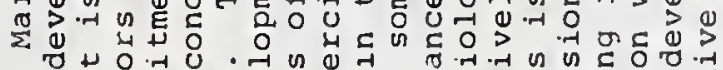
d की

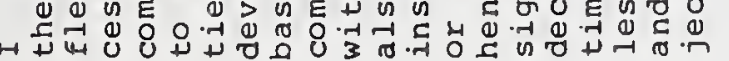

(1)

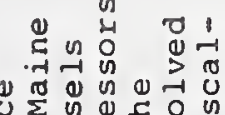
ช $\begin{gathered}0 \\ 0\end{gathered}$ वृ

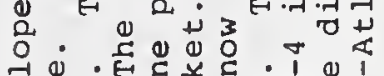

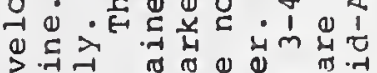

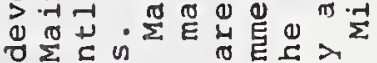
ช $\Sigma_{\pi}$

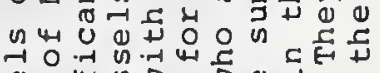

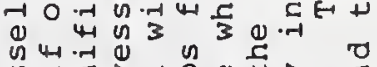

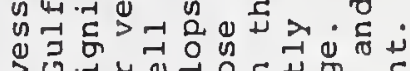

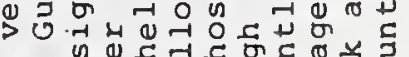

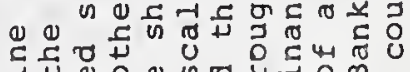
๑ั

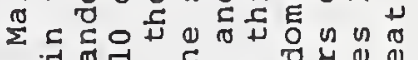
ช ข

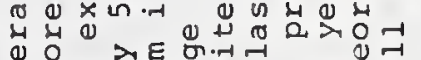

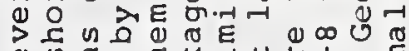

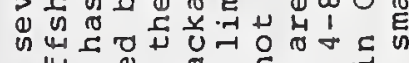

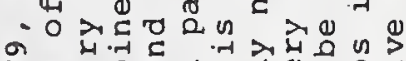

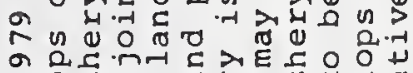
$\rightarrow$ o म

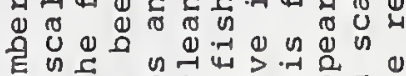

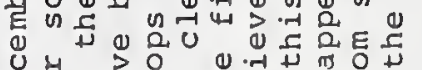

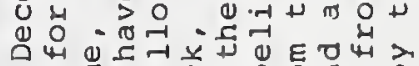

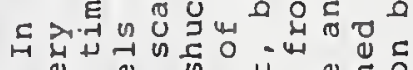

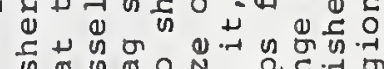

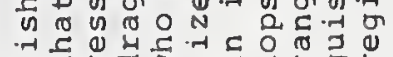

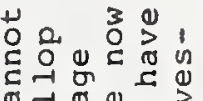

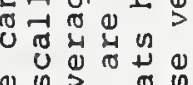
$\sum_{10}^{10}$ is

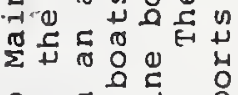
+ 不年 3 -

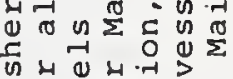

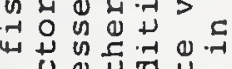
$\rightarrow \begin{aligned} & n \\ & 0\end{aligned}$ 工

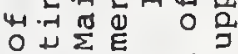

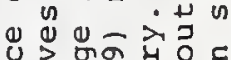

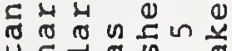

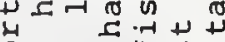

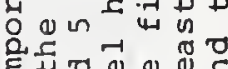

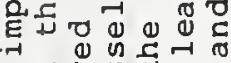

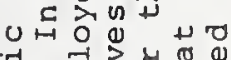
है. ठำ 1)

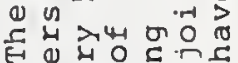

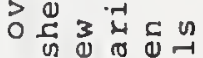

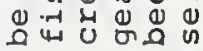




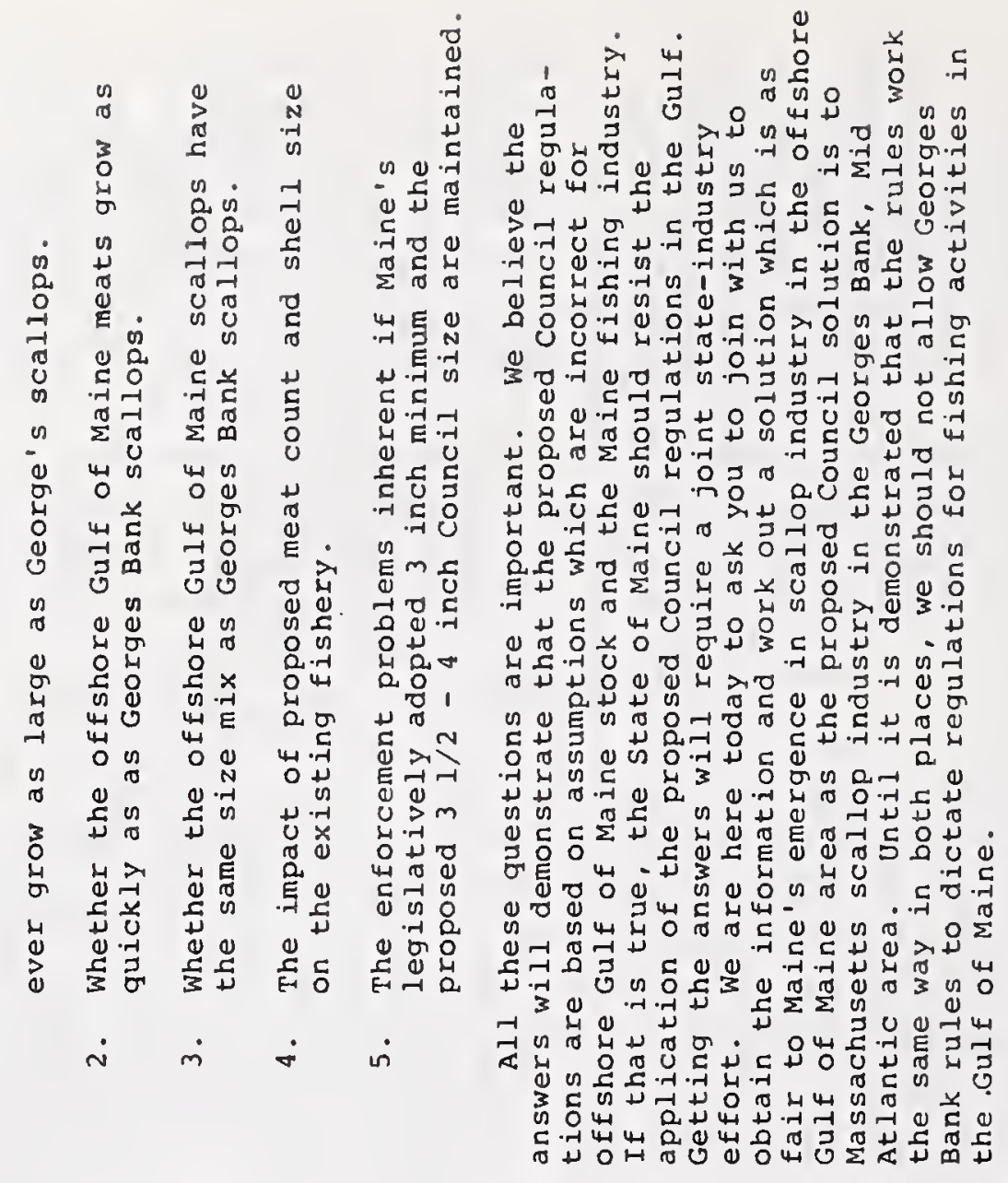

苞苛

ᄃ

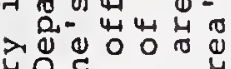

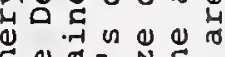

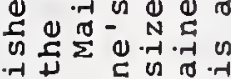
O. ज.

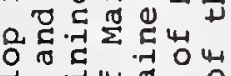

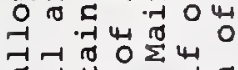

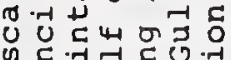

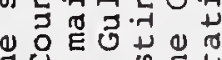

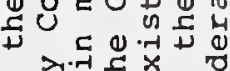

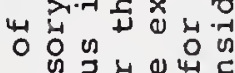

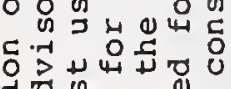

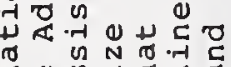

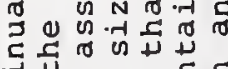

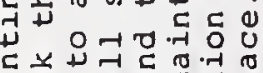
过的会 \& Q

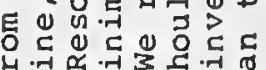
फ

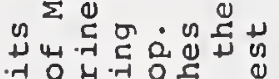

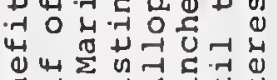

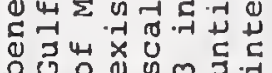

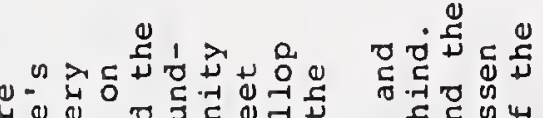

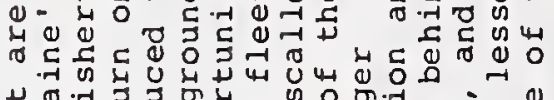

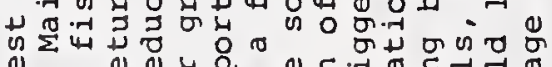

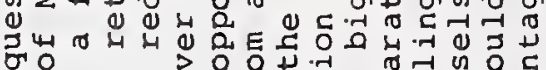

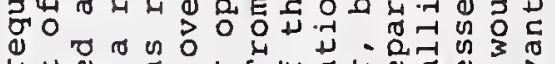

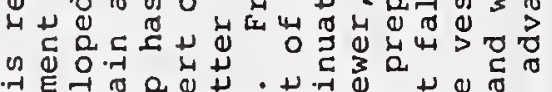

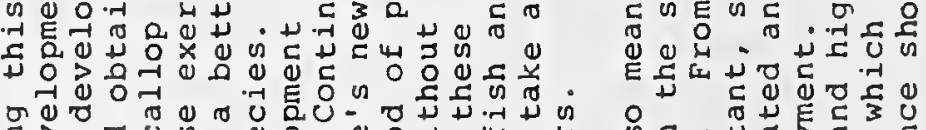

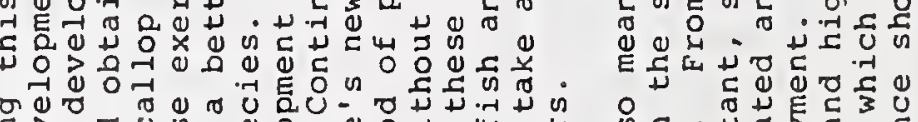

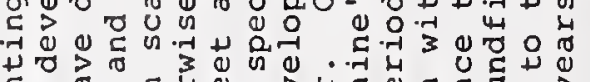

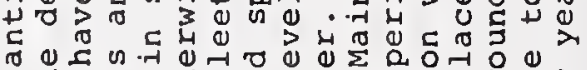

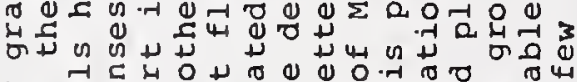

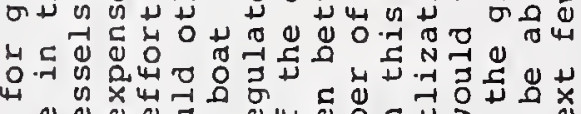

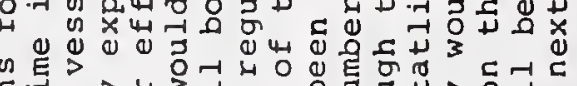

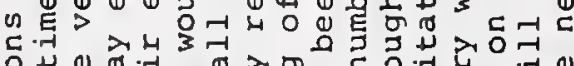

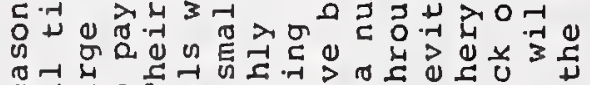

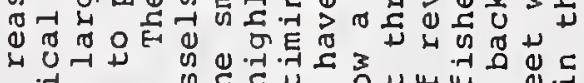

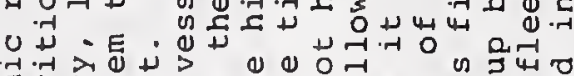

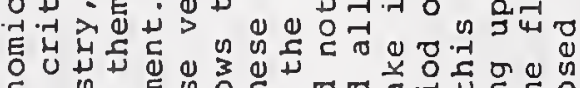

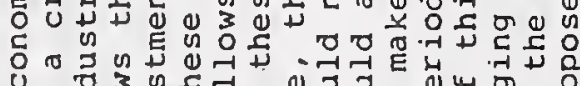
U.

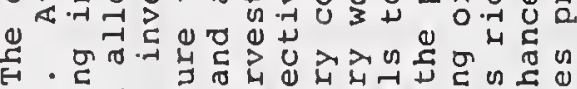

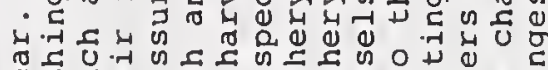
ه

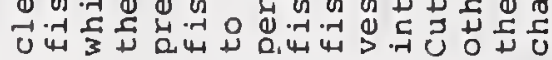

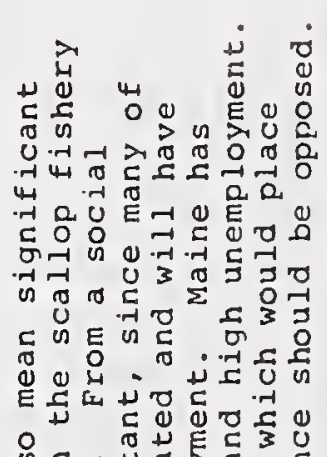

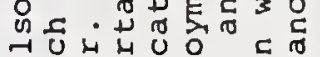

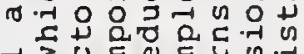

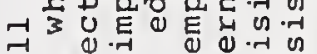

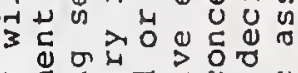
入 पै की

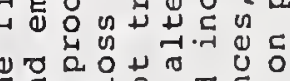

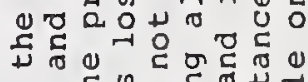

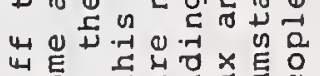

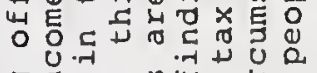

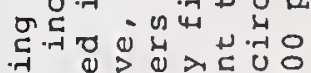
巫 उन

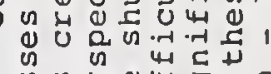

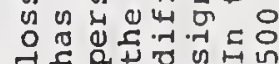

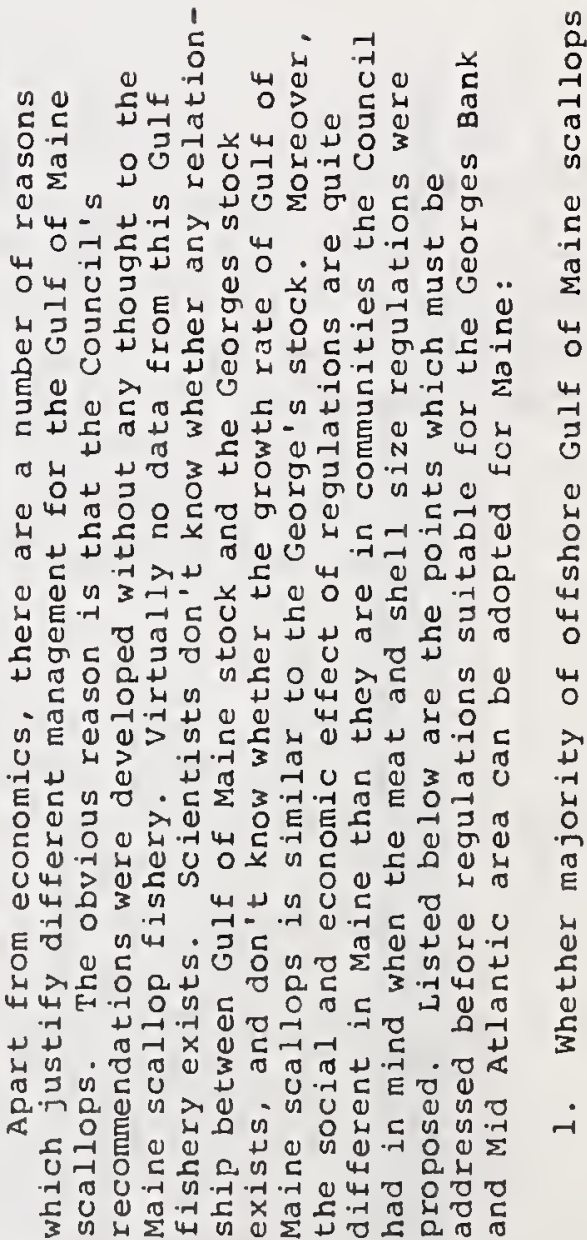




\section{National Fishierman May 1980}

\section{Booming Me. Scallop Fishery May Suffer From Overfishing}

The Gulf of Maine has become a anall britht spot in a generally, bleak New Englend scallop fishery.

The offahore arens of the gulf, carrying distinctive names like Tilles, Three Dory Ridge, Fippennies Ledge and Lubes Oround, have dways supported some scalloping activity.

But if wasn't until late lest year that come of the larger scallopers from down the Atlantic Coast and some converted Maine bottom trawlers began massing on the prounds, seeking an alternative to the heavily fished beds off southern New Engañd.

Approximately 20 of fshore scallopess are fishin regulurly, each with crews of eight to 12. The effort is keeping 200 to 300 shoreside workers in jobs that didn't exint before the recent boom. Ex-vessel prices of over S4 per Ib. and landings averagins up to 40,000 lbs. per week along the cont have combined to make a sienificant contribution to the economies of constal communities from Gloucester, Mass., to Rocldiand, Me.

New Bedford, Mass., ot course, ramm. its position as the top scallopins port, reporting landines from Nantucket Shouts and western Georges Bank that are up to. five times greater than those in the Culf of Maine. But the smaller northern firbery is still important though it has alreedy become controversial and its future remins uncer. tain.

Most of the boats involved in the fishery are "shell stocking," a fishing method which some say is destructive becanse the scallop shells are brought ashore for shuck. ing rather than being shucked on the epot and cast overbourd.

The problems with this, erities ay, are twofold. First, the absence of shells in the beds reduces the chances of scallop spet, or. spawn, surviving because they have nothith to artach themselves to for prorection. And, secondly, not topping to shuck at sen tives the fishermen more time to fish, leading to a more rapid depletion of the atocks.
Countering these claims are fishermea who say they see very little spat aruched to shells - and also think the shell stocking creates jobs ashore which help distribute the wealth from the fishery.

The issue of conservacion is also in question, with some saying the small scallops be ing harvested should be allowed to grow, Morrill says.

Counts of scallop meats per pound range from about 45 to 60 , depending on who is shucking and how careful they are about removing the meats.

If the scallop management plen as currently proposed by the New Entend Fishery Management Council's scallop committee were in effect today there would be no Gulf of Maine fishery because the commitree is proposing a 30 -meat count.

'Some people say they're too amull and come bay they're just smalter scallops then what you see down South." Morrill says.

"There is also the "cycle" theory, which coniends that the scallops are abundant now and will die off if not harverted, an idea undoubtedly being helped along by the increased pressures from more and more vesels bearing of the gulf boom and movin in to get their share.

- "No onel've talked with thinks this is a imajor new discovery," Morrill says, addins that estimates of the economic life of the beds range from a few months to a year.

There has been pressure from the amalles venels who have survived in the fishery very quietly'for years to exclude the bigrer veasels they fear will eliminate their fishery in no time. In the absence of any fedenal managemeat scheme, however, this is innost impossible.

Mine has a six-month residency requirement for the license neceasary to land callops at the rtate's wharves, but this rule has been easily circumvented by hiring a Maine-fisherman and purting the permit in his nome.

New Hampahire and Mrraschisietiö. meanwhile, have no such rules and are as close to most of the grounds as the Maire ports.

"Wait "til this summer," siys one sealloper out of Gloucester who has quietly made a living off the gulf fishery for sevenl years. "They"ll wipe us right out with all those boats frow down South... then they'll go away and we'll be left with our litthe bouts and nowhere to fish."

$-T$. Sullivan 

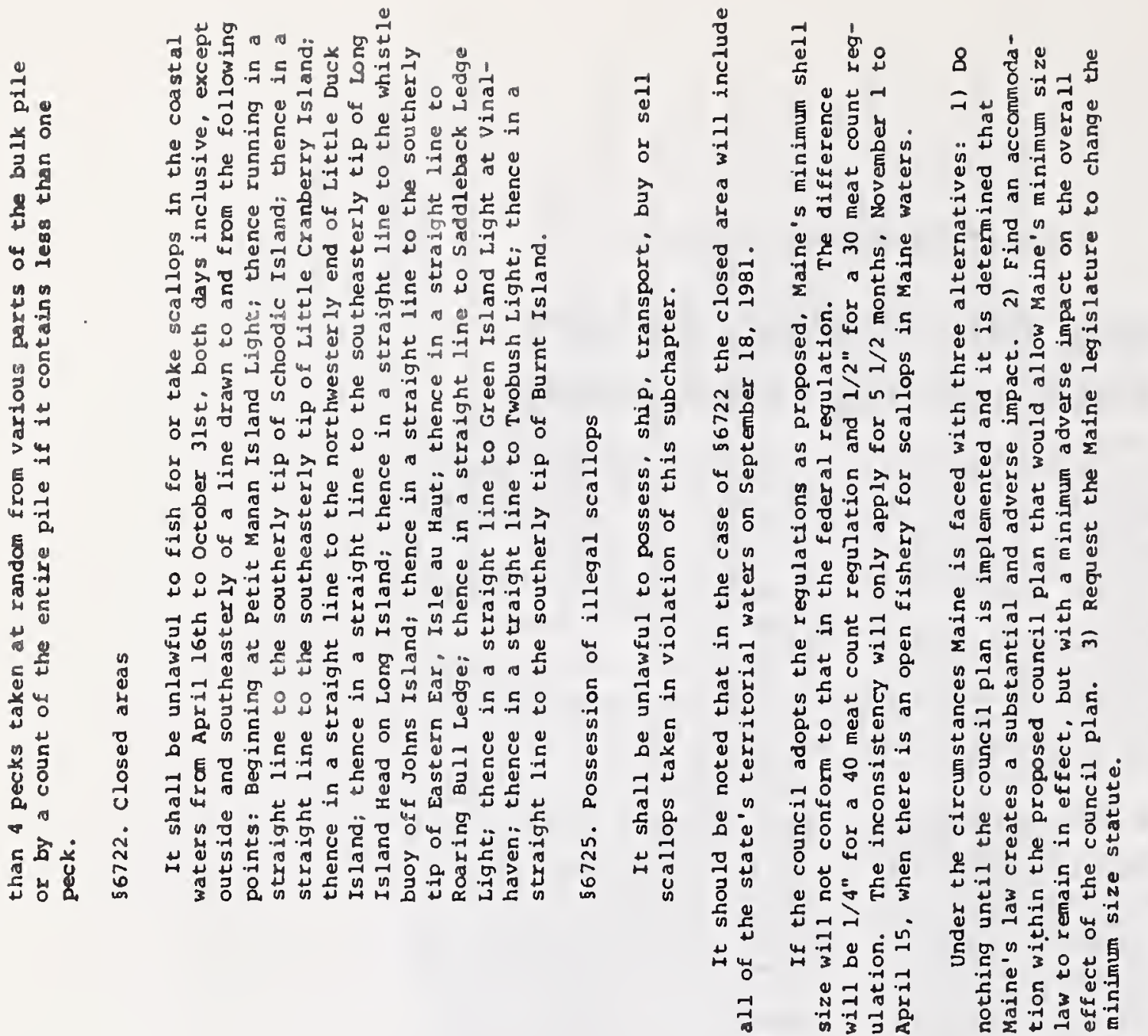

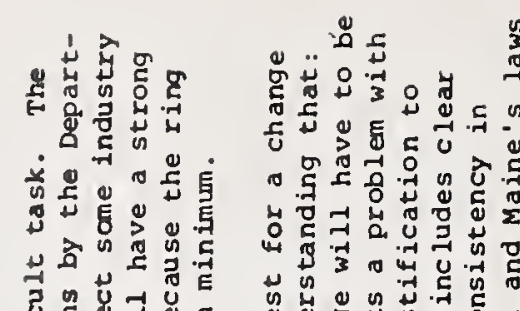

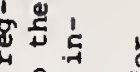

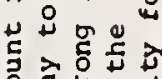

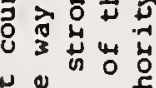

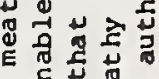

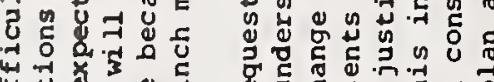

年

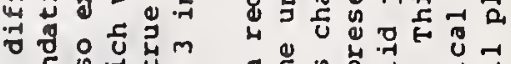

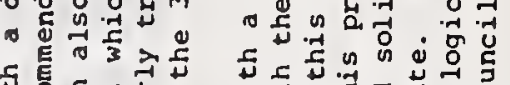

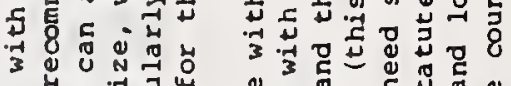

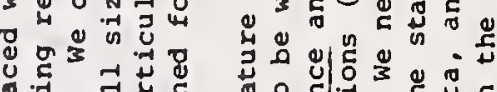

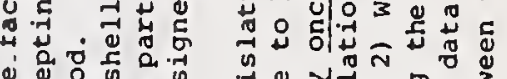

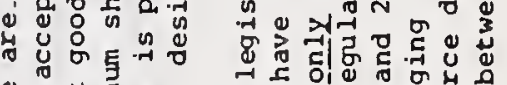

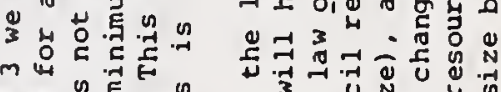

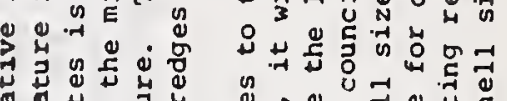

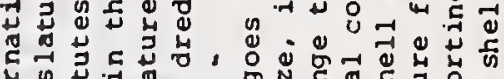

y.

न

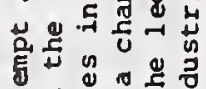

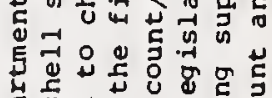

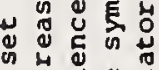

०

य.당

击

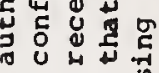

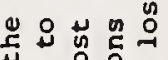

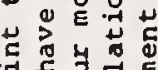

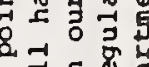

ज政总

సี

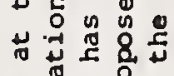

我寻艺范。

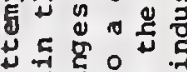

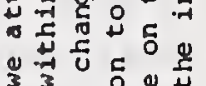

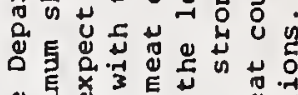

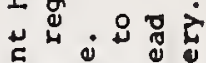

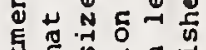

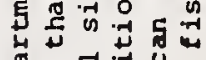

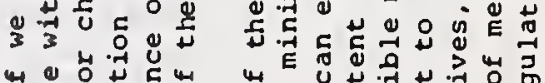

过

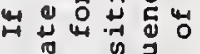

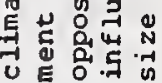

出 E⿱

我行

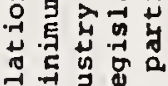

in

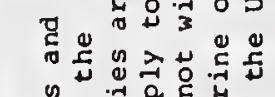

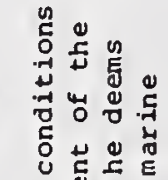

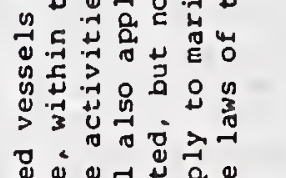

年站要

空突莒

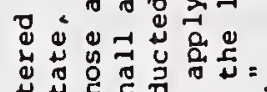

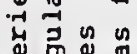

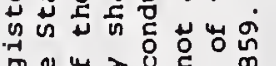

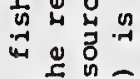

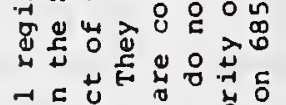

of

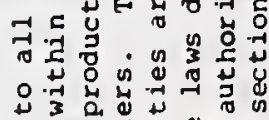

है.

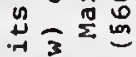

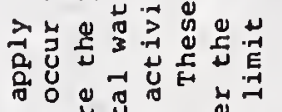

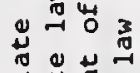

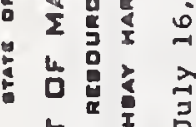

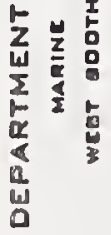

娄苞总

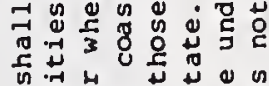

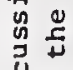

出

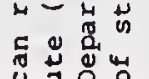

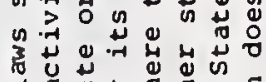

击

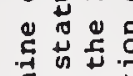

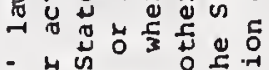

जु

的出 心

की

岁

₹

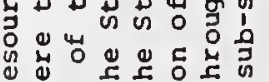

西出

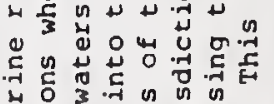

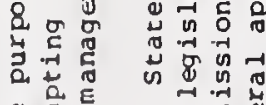

声志㝴焉

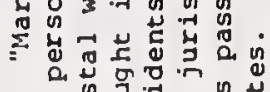

造哭嵒出

S.

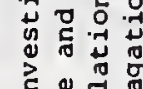

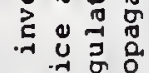

入

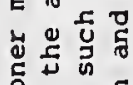

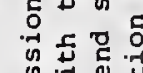

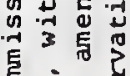

害哭台跑

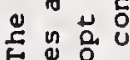

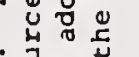

is

唇过

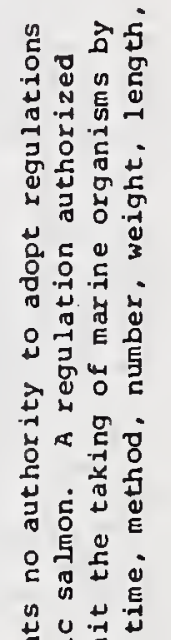

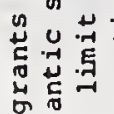

岕完示兑

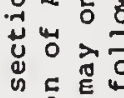

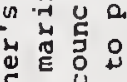

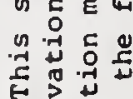

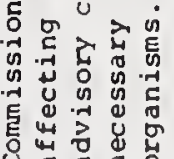

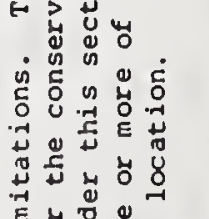

드웡

उह है

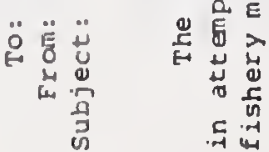

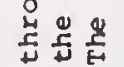

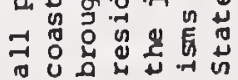

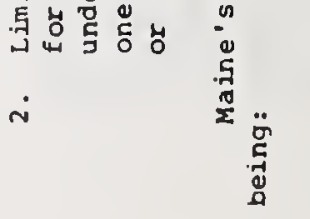

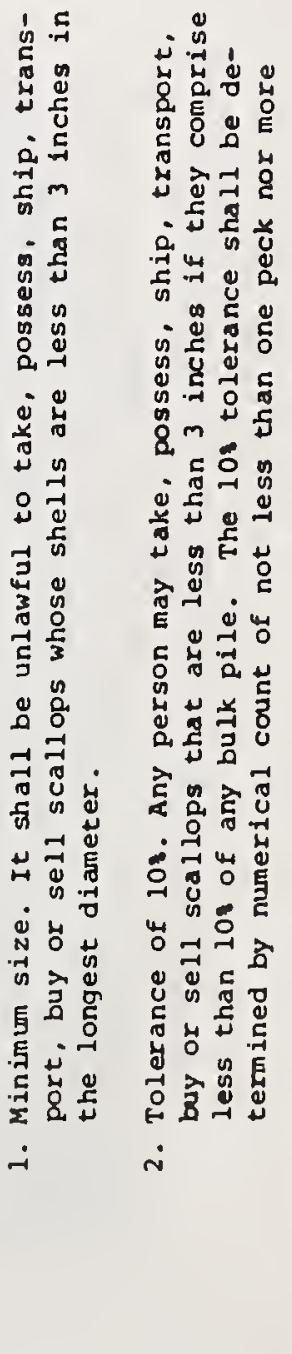


Finally, in an effort to resolve the discrepancy between the 30 meat count proposed in the Scallop Plan and the Canadian 40 meat count, the Council voted to "request the secretary of Commerce, at the appropriate time, to use all possible influence to seek resolution to the discrepancy over sea scallop meat size". This vote occurred in spite of a Regional Director suggestion that the Council could better address this discrepancy in a more direct manner by way of a "possession" regulation set by the Plan. Council staff had noted that "developing a possession restriction was a difficult issue and one that could possibly slow things down". Hence, the council took no position on a possession limit at these meetings.

\section{FMP Completion}

At a June 24, 1980, Committee meeting Council staff provided a memorandum reviewing Council action on the sea scallop FMP which was judged by the staff to be complete with a few exceptions. This review is included here.

The Committee, using this review, "hastily" approved the Plan in order to submit it to the council the following day. The meeting did not begin until very late in the afternoon since a quorum was not established until then.

During the next two days the council reviewed the Plan and approved it for submission to NMFS Washington, but subject to a final review and approval of the completed document by the scallop Oversight Committee. This was necessary since some sections of the Draft were "reserved"; e.g., continuing fishery management program, and needed to be written. The purpose of Council approval before the Draft was finalized was to save a month's time; i.e., to submit the Draft to NMFS to begin the formal review process and to submit reserved portions later on. It was expected that the accompanying DEIS would be completed at the end of July then submitted to EPA as a "Draft Discussion Paper" to start the clock on that public review process leading to mid-August public hearings.

The Diraft was approved in spite of the hesitancy of some members who did not like voting on Plan which was not complete. Assurances that all reserved sections would be reviewed by the Committee prior to submission to Washington assuaged these individuals' concerns.

The Council also decided that "possession of scallops of a count greater than the Plan-recommended size be prohibited at the level of first transaction in the U.S.". 


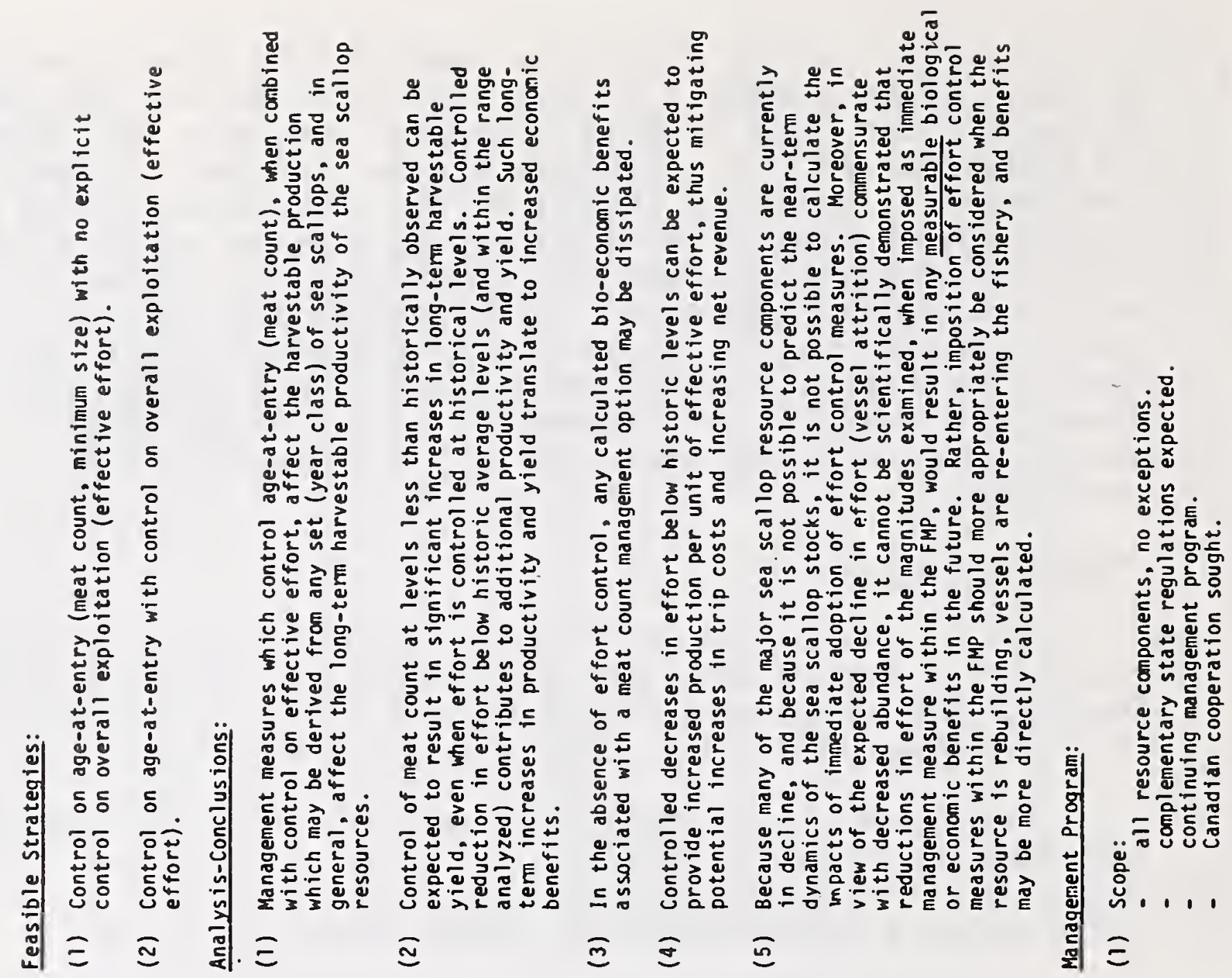

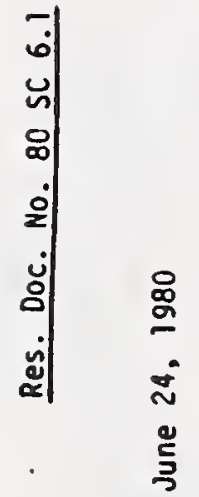

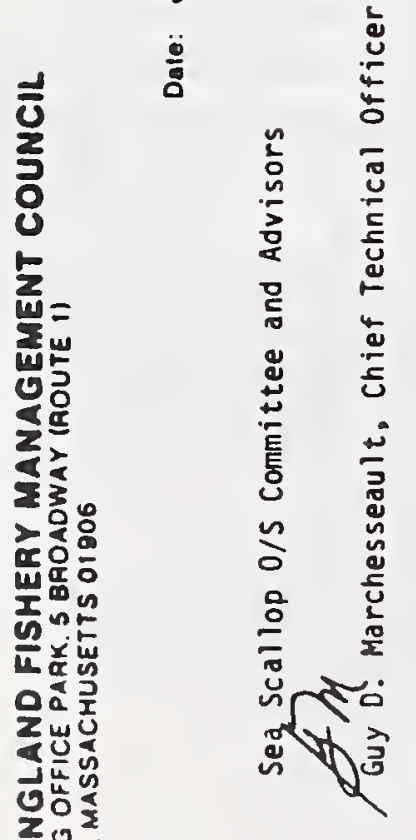

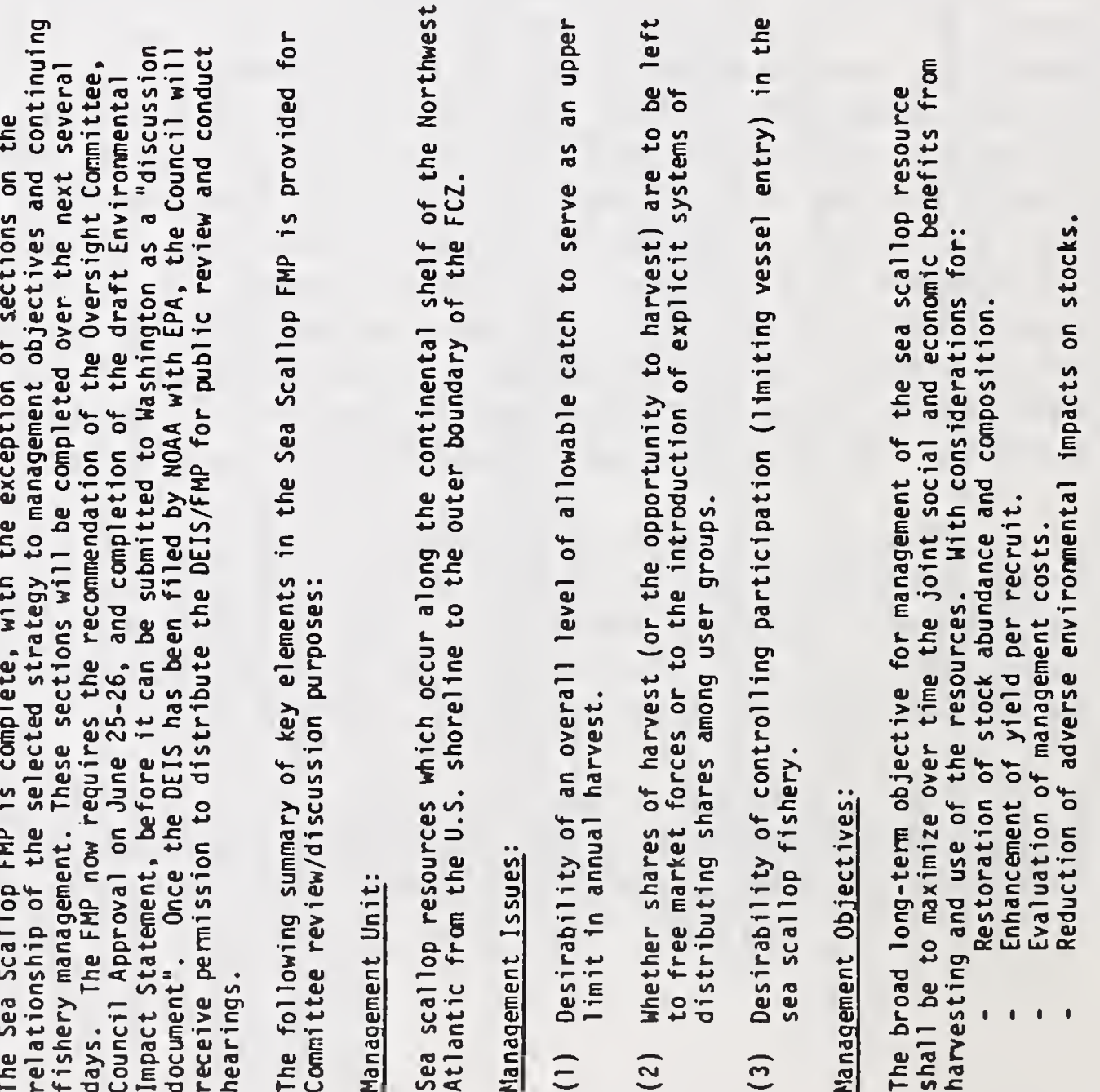




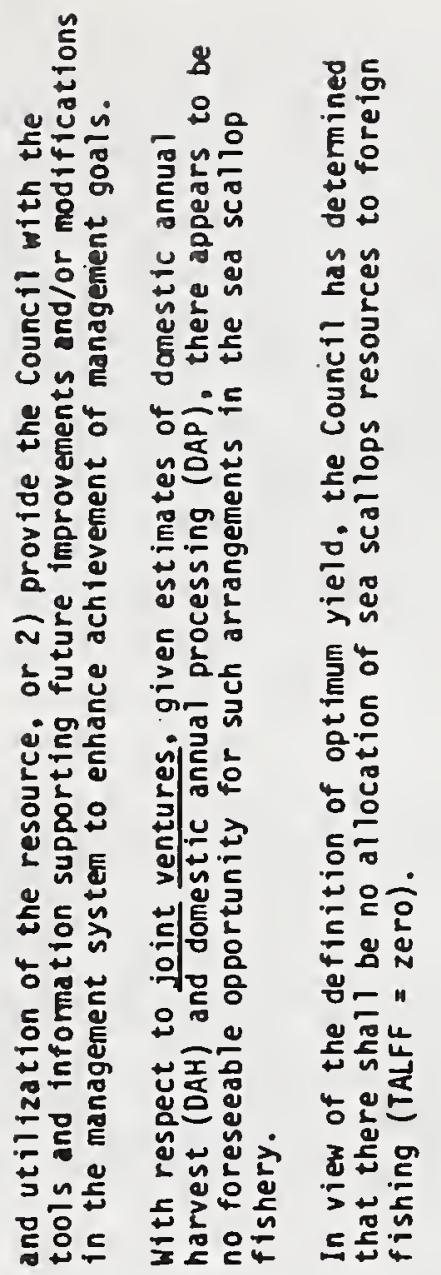

₹

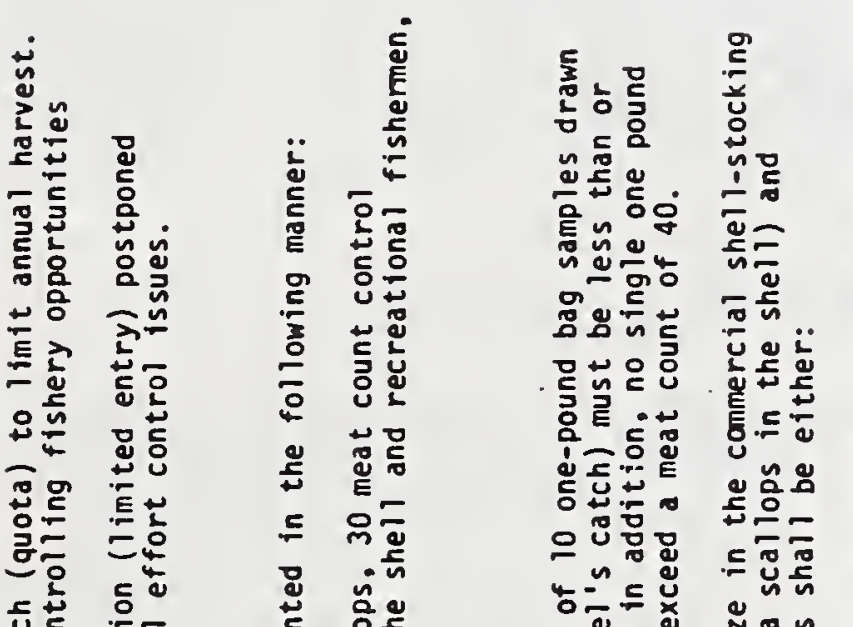

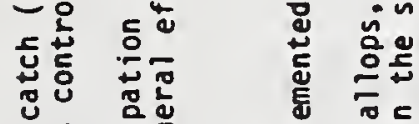

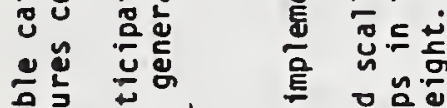

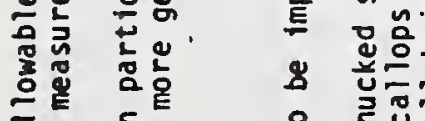

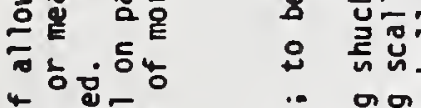

눈

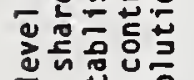

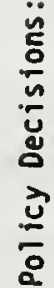

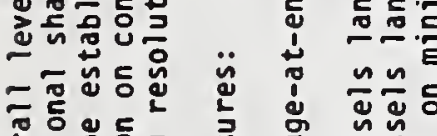

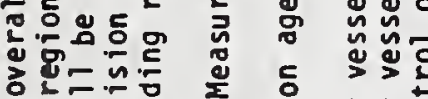

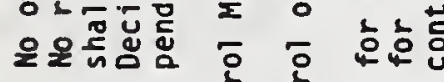

㐫

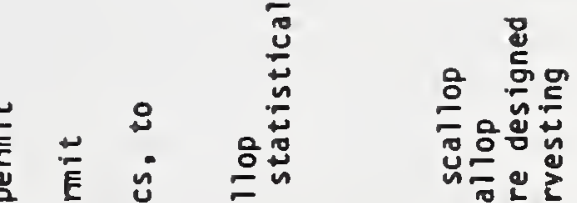

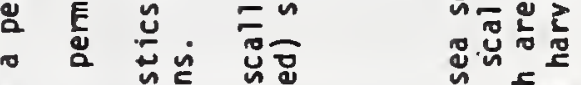

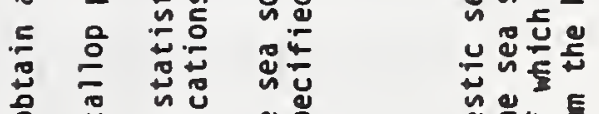

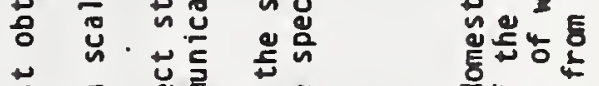

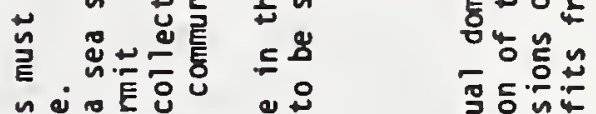

นับ

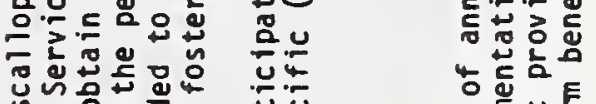

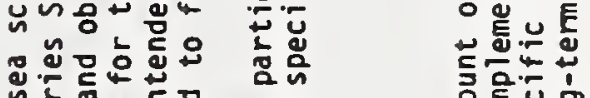

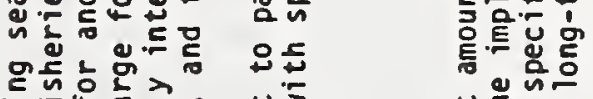

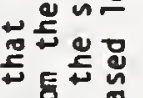

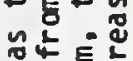

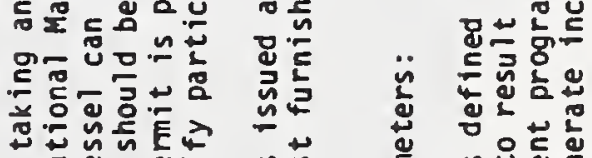

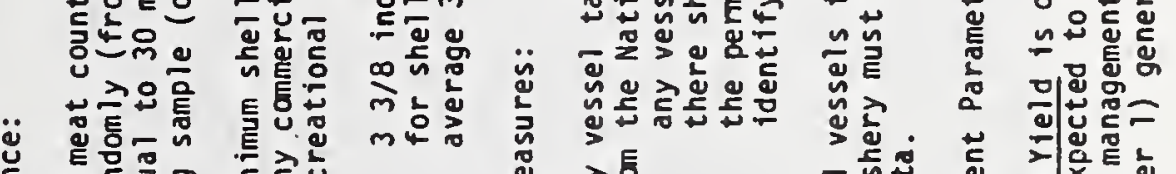

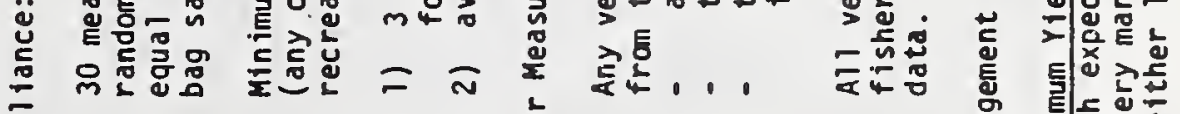

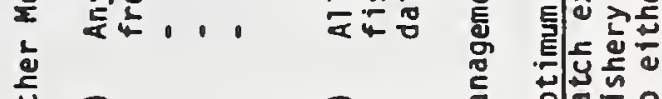

¿ a

$\Xi$ 


\section{Continuing review}

The committee met on July 21 to review the reserved portions of the Scallop FMP which were to be submitted to Washington sometime in August. At this meeting and at July 30 and 31,1980 Council meetings some additional insight into the review process was provided by the Executive Director who stated that once in Washington the FMP/EIS would be reviewed by the NOAA Office of Environment and Conservation before being filed with EPA. After filing with EPA public hearings would be scheduled at the end of September or early Octuber. The Plan was also forwarded to the Regional office of NMFS for its internal review.

\section{Comments received}

On October 20,1980 , the Council received results of a critique of the Draft EIS/Discussion Paper by Washington and the Regional Office. Revisions were requested to address three principal concerns: the EIS did not contain all necessary information in required format; the identification and discussion of issues and alternatives needed to be expanded; and some discussions needed to be broadened to clarify content.

The "long" review period and nature of some of the comments disturbed many Council members. The central council concern appeared to be the requirement that every FMP be submitted with a DEIS and a Regulatory Analysis (required by Executive Order 12044). This concern led to a long discussion on results of an October Council Chairmen/Executive Directors meeting.

\section{Council Chairman Robert Jones stated,}

"There was a rather long discussion of the plan development process at the meeting. One of the questions involved the so-called 'fish policy group' which a number of people had made reference to as the faceless bureaucracy that FMPs go through. There was a concern not unlike what was expressed here yesterday as to, "who are these people that review the plans?" Mr. Leitzell addressed this matter to some degree indicating that this group consisted of himself, Dick Frank's Deputy in NOAA, NOAA General Counsel, and Chief of the Office of Planning and Policy. It is this senior policymaking group in NOAA/NMFS which in fact has the final say in regard to approval of plans and amendments. To date there has been no backing-down from the judgement by this policy group. 
There was some discussion about Regulatory Analyses and Environmental Impact statements. I think one of the things that became clear was that nobody really likes these two ancillary aspects of the Plan. development process. However, it was clear that it was going to be necessary to prepare the regulatory analysis and in particular the environmental impact statements with the same standards that we prepare the fishery managment plan. There was concern expressed that most of the councils weren't really doing them in the way that NEPA or the Executive Order had indicated. The point being that these analyses should be done in concert with the plan development rather than sitting down after the fact and developing the Environmental Impact statement or Regulatory Analyses. I am sure we will be seeing some additional guidelines in that regard.

There was some discussion of the relationship between the Regional Offices and the Washington office and the Councils. Terry Leitzell said that it was his policy that in fact.the Regional Offices had a significant level of authority in the review and approval process of plans. At least two out of the three Regional Directors that were present seemed quite surprised at the statement. It is pretty clear that there is not a general understanding of just exactly what the policy is in this regard. I think the point was made very clearly that all the councils felt there should be substantial additional involvement in this whole process by their respective regions and that most of the problems seem to center around the Washington office: I suspect we may be seeing some changes in this regard, and I suspect they will be favorable from our standpoint."

Jacob Dykstra added,

"I want to make a few comments on the EIS situation. As I understand it, the primary responsibility concerning EIS's rests with people at the Environmental Protection Agency and CEQ. These people are primarily supposed to be the watch dogs of the environment. The representatives of the councils I heard speak at the San Juan meeting said that it was their understanding that there have been practically no problems with these agencies on any of these EIS's. FMP's go to them with the EIS and they sign off on them practically automatically, but the guidelines in NMFS/NOAA are far stricter than those of EPA. It gives the impression at least to me

that NMFS/NOAA has decided to be the busy-bodies in 
this particular area. They have just assumed the authority that, look, we are the ones that are going to nit-pik the environmental impact statements and make sure that everybody does everything all right and follows the law just the way the guidelines say. If this indeed is the case, I think this is one area that is very important to look at. We have to look at whether we want to get some legislation which says NEPA does not apply. Perhaps we can keep certain pieces which may be good. It just seems to me that this NEPA business and the interpretation of NOAA is something that is really screwing up the works."

Robert Hanks, then Deputy Director of NMFS Regional office countered:

"I would just like to comment that this is not just a dabbling on the part of NOAA/NMFS in the process. It is a parallel review process. NEPA takes a path and the FMP takes a path. This more intensive look at the quality of the EIS.s results from CEQ looking at the problem nationally. They have told us very clearly that they will not accept EIS's any longer that do not meet certain standards. Therefore, if we are going to proceed with the development of plans and get them through the system, they are going to have to be of a better quality than they have in the past."

Jack Dunnigan agreed with Mr. Dykstra and stated,

"I think Jake is absolutely correct when he says that NOAA would like to hold its actions to very high standards of environmental review. It isn't really accurate to say that $C E Q$ and $E P A$ are the agencies that are in control of this process....

I think NOAA does try to set some very high standards for environmental review. It believes it is an environmental agency, and therefore, does have to hold its own actions to some very strict scrutiny. It is true, as Bob says, that there has been some criticism leveled as NOAA very recently by the Council on Environmental Quality with respect to the overall quality of its EIS's. That has resulted in a general tightening up of NOAA's approach to EIS's coming out of the agency." 
Addressing the problems

To address NMFS/NOAA problems with the EIS/FMP, a meeting of Washington and Regional Office people with the Scallop Committee and Council staff was set for November 10, 1980 , and reported on at December 3 and 4 , 1980, Council meetings.

According to Daniel Arnold, there were no serious problems with the necessary modifications of the EIS and FMP, and the rewrite was to begin in mid-December. Douglas Marshall noted that the majority of changes were in the EIS and were principally format or presentational changes. There were a few changes in the text of the Plan but none were substantive; i.e., none would change any strategies or policy decisions on measures involved and included in the plan.

The Committee was given the go-ahead to resubmit the DEIS/FMP when the revisions were made. Council approval was not considered necessary.

\section{Resource status}

In December the NEFC presented. its stock status report. That report read,

"Sea scallops (Placopecten magellanicus) occur along the continental shelf of North America from the Straight of Belle Isle south to Cape Hatteras, North Carolina. Sexual maturity may occur as early as age 2, but scallops less than 4 years old probably contribute little to total egg production because of low fecundity. Spawning occurs in late summer or early fall, varying slightly between years and areas. Sea scallops may live to approximately age 20 .

The 1979 total U.S. sea scallop catch of 14,256 metric tons (MT) was about 2\% lower than the 1978 catch of 14,482 MT. USA Georges Bank landings in 1979 were 6,666 MT, a 19\% increase from the 1978 catch of 5,598 MT. The 1979 USA Middle Atlantic catch of $7,156 \mathrm{MT}$ was $17 \%$ lower than the 8,641 MT landed in 1978. Canadian catches on Georges BankMiddle Atlantic area were 23,643 MT, 11\% less than the 26,671 MT caught in 1978 .

The 1979 NMFS sea scallop survey indicated that, as a result of the heavy fishing pressures applied over the last few years, the 1972 year class no longer held its position of prominence, and abundance had subsequently decreased in all areas. As in 1978, there was no evidence of improved recruitment which might have alleviated the trend of declining abundance. 
As anticipated early in 1979, decreased abundance in the South Channel and New York Bight areas has resulted in a shift of more U.S. effort to the Northern Edge and Peak of Georges Bank which, in conjunction with sustained pressure from the Canadians, appears to have significantly reduced the abundance in that area. Without significantly improved recruitment, abundance will continue to decline unless fishing effort (and mortality) is reduced."

Hearings

A series of public hearings were held from Maine to North Carolina to solicit comments on the DEIS/FMP. As expected views were diverse particularly on appropriateness of the 30 meat count and shell size restriction and wisdom of shellstocking. Regarding meat count, most commenters felt that it was more sensible to begin the Plan with a 40 rather than a 30 meat count. This position was emphasized by James Costakes, General Manager of the New Bedford Seafood Producers Association, who believed that the best opportunity to reconcile differences between Council and Canadian meat counts was by beginning the Council Plan at 40 count (with a $10 \%$ tolerance) with the expectation that the count could be reduced "when it makes sense for the fishery and the industry". He noted that the existing Canadian Plan had a 40 meat count provision with a $25 \%$ tolerance effectively bringing the average count for any trip up to 50. He was also adamant that, "the immediate imposition of a 30 meat count would result in very significant short-term losses (to the industry) and could have severe long-term consequences". His entire testimony. is included here.

Many felt that shellstocking should be prohibited. James Costakes noted that this prohibition would be a strong conservation measure. In Maine, however, while it was conceded by some that shellstocking was less desirable than shucking, the practice was still considered to be of great importance to some ports, especially Portland. Of note, Portland shellstockers not only defended their way of harvesting but argued that a shell size restriction larger than $3^{\prime \prime}$ would put them out of business. They suggested that the FMP adopt Maine's 3 " minimum shell size.

The proposed possession limit was not as controversial. As stated by Daniel Arnold at May 26 and 27 , 1981, Council meetings, "the possession issue surfaced in every hearing. Everybody was in favor of the inclusion of the possession mechanism in the Plan. My own feeling is that we should go for it as strongly as possible." 


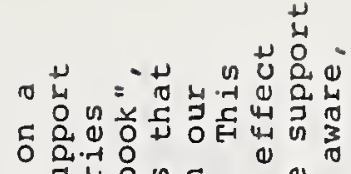
○ 山ै

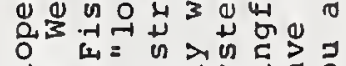
न-

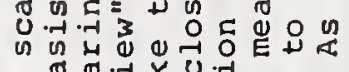

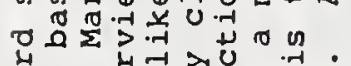

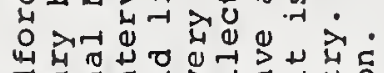

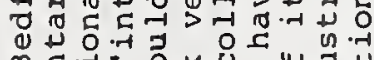

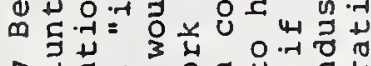

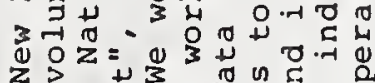

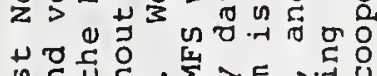

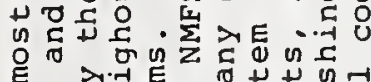
ED.E

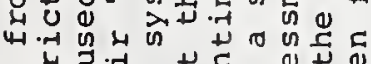

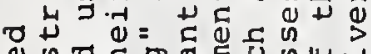

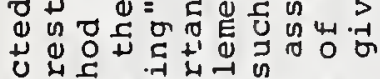

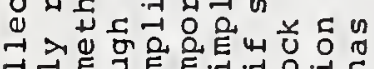
ช

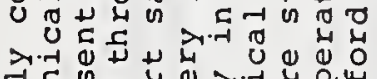

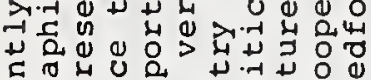

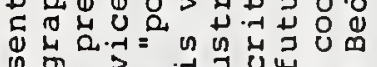

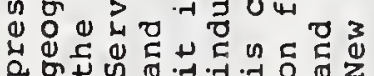

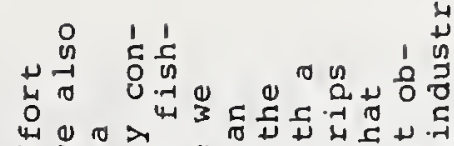

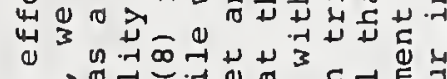

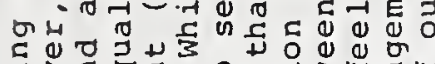

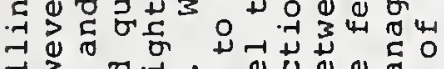

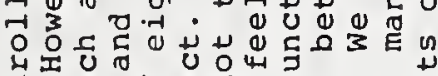
艺. ช०่ 山. ○.

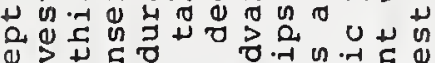

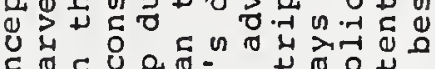

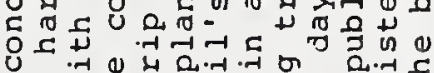
ن ه ᄃ

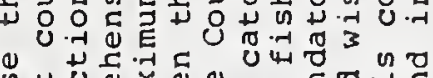

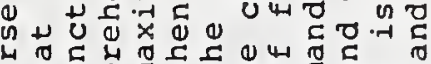

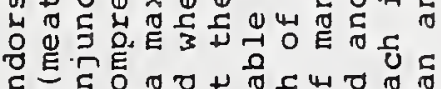

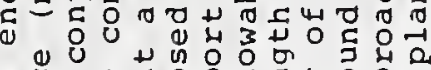

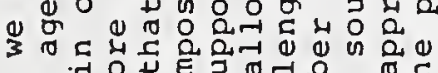
六

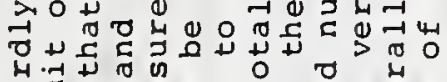
E. ช. 入े

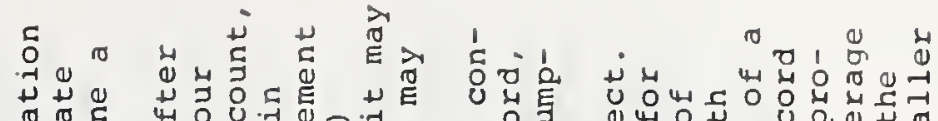
ช.

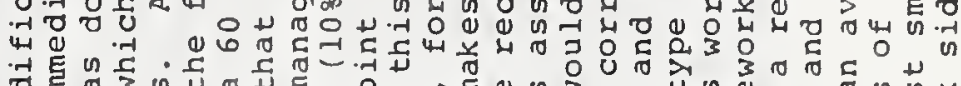

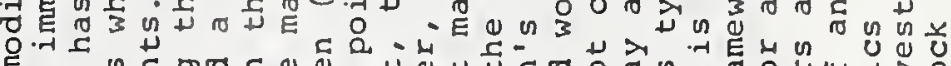

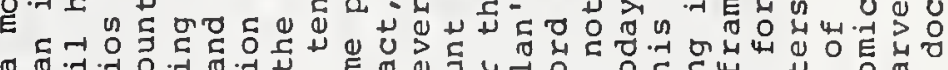
ه

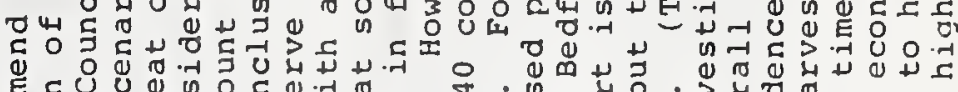

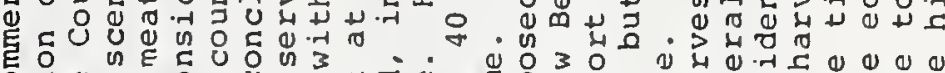

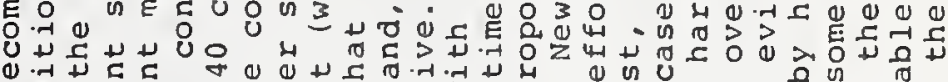

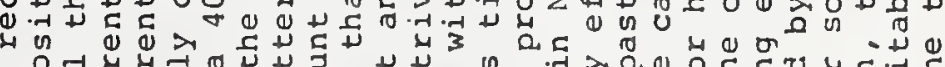

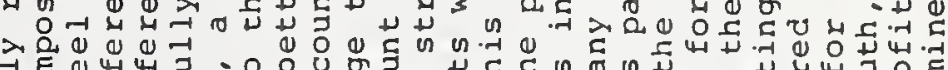

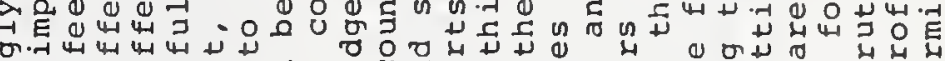
。

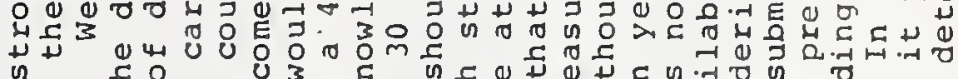

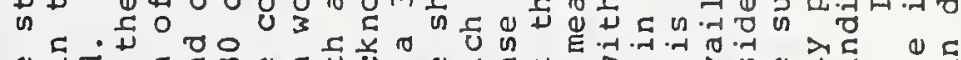

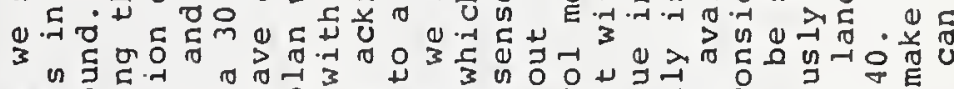

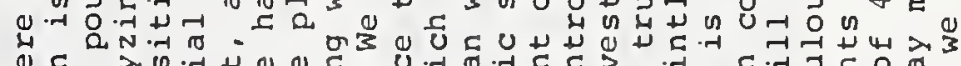

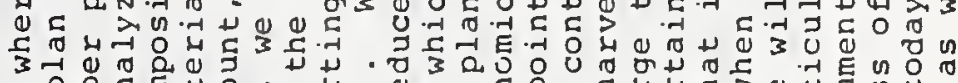

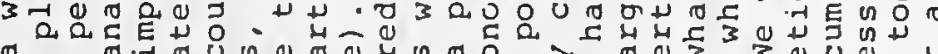

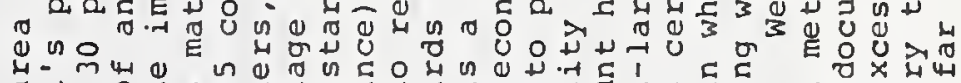

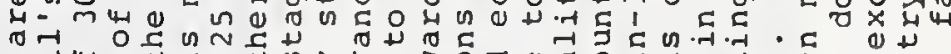
ब

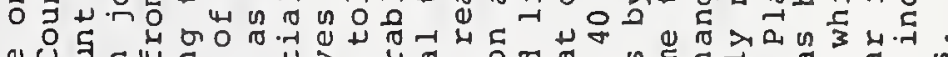
ه

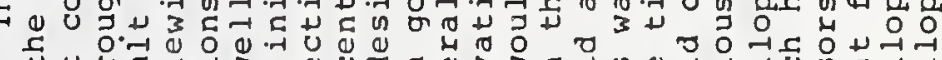
山

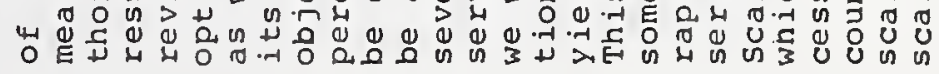

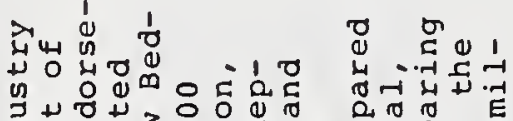

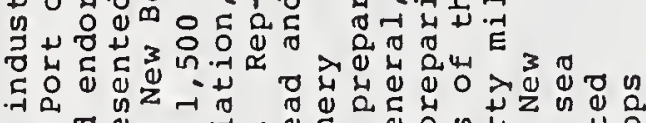

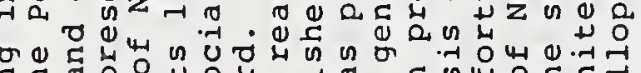

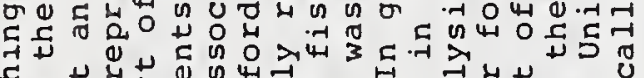

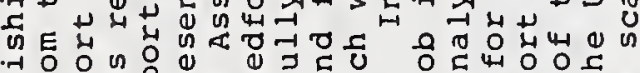

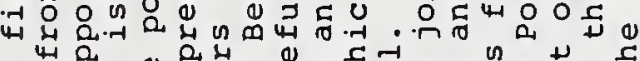
入े

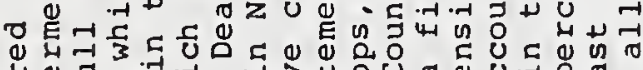
山ै

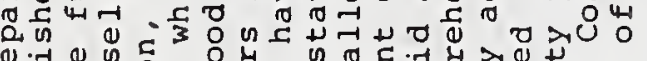

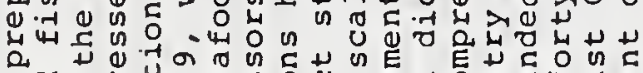
2.

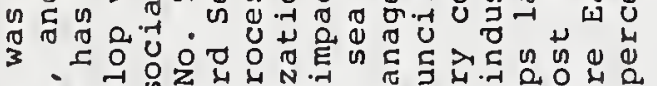

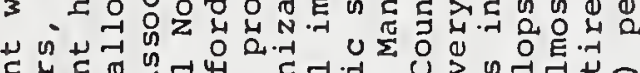

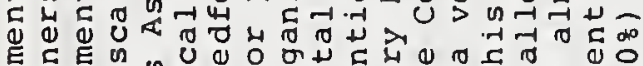

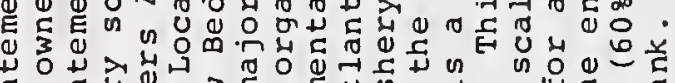

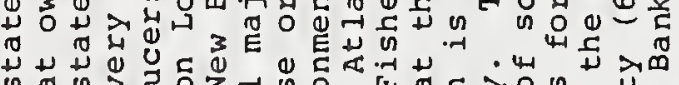

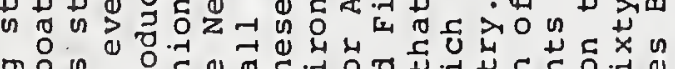

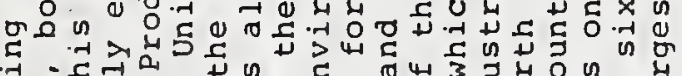

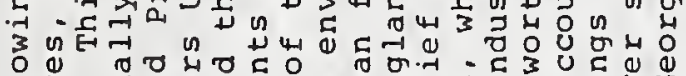

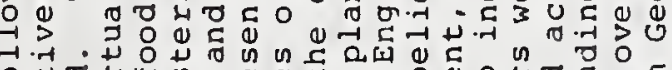

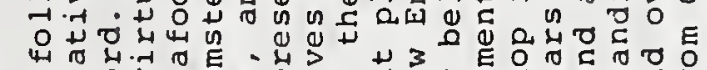

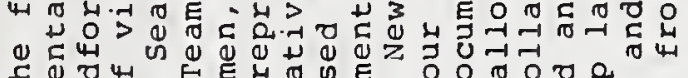

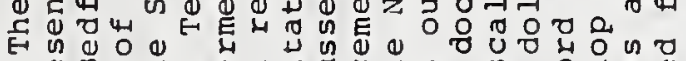

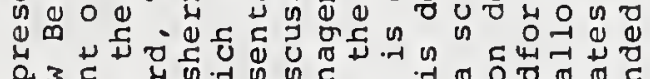
等

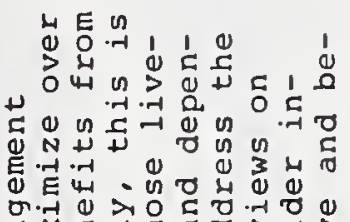

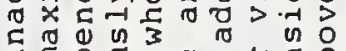

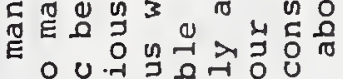

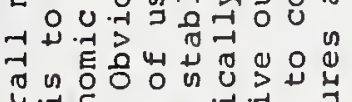

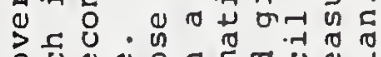
ว.

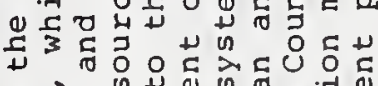

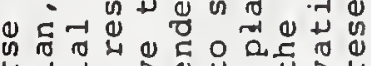

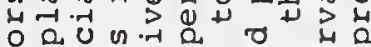

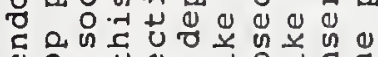

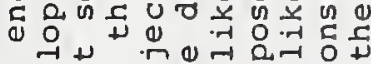
خ들. $\exists$ J

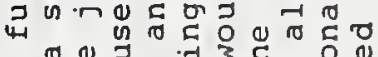

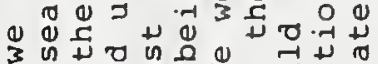

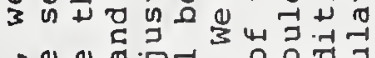

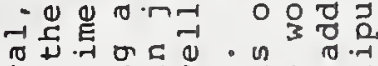

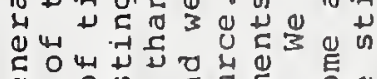

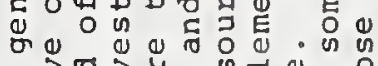

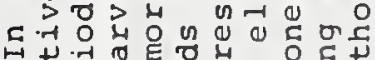

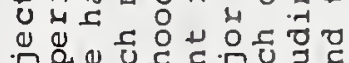

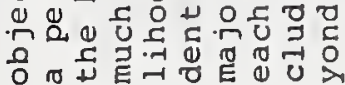

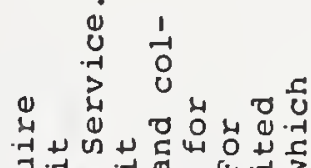

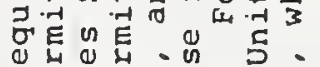

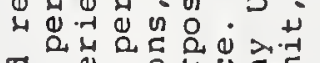

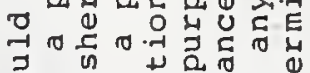
ठี.

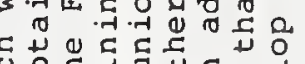

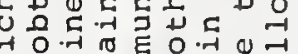

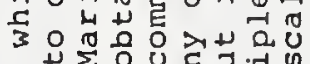
द शे हैं

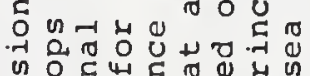

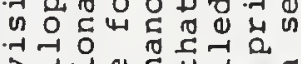
>न

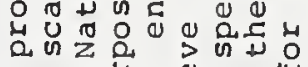

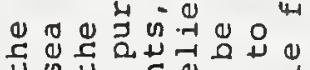

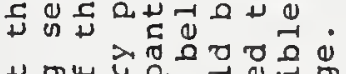

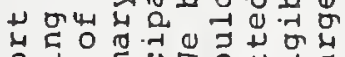

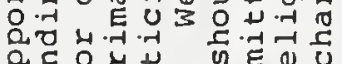

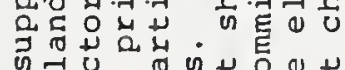

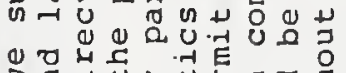

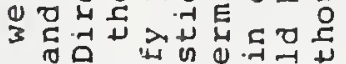
-

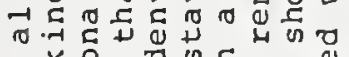

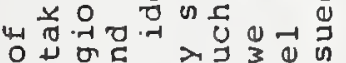

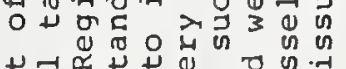

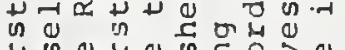

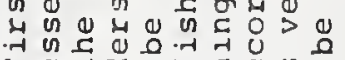

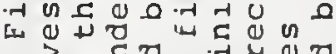
E 5 马

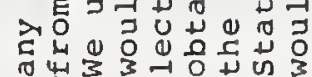

(1) 갱

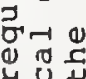
वे山

青年 0

苟范

ᄃ

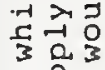

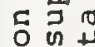
ด

จ

늘

ذّ

त四

웜

号绐品

उ ᄈ 든 $\frac{}{3}$

굥 잉 呚 品

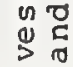




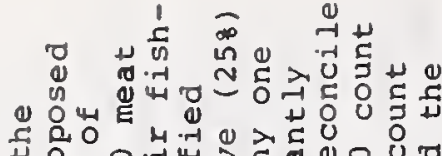

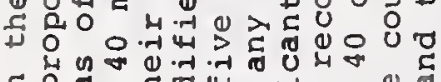

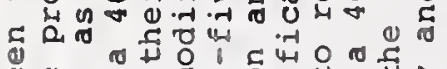

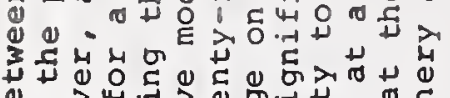
ब

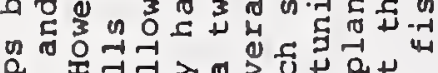

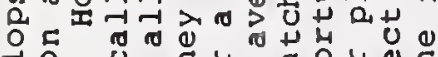
-

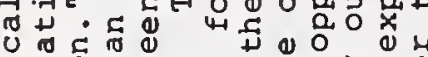

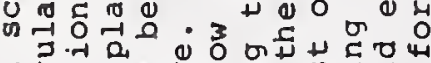
ช

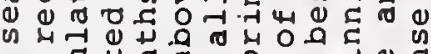
u

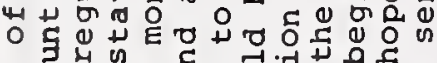
N

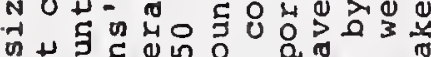

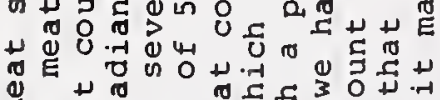

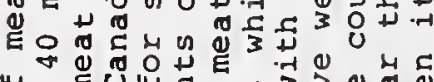
山

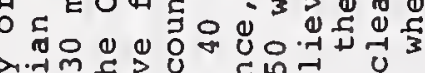

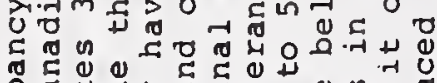

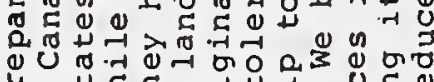

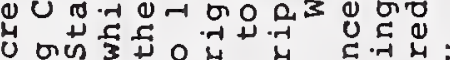
जी ชี

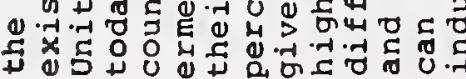

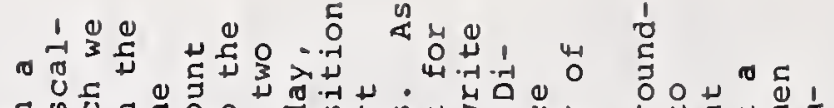

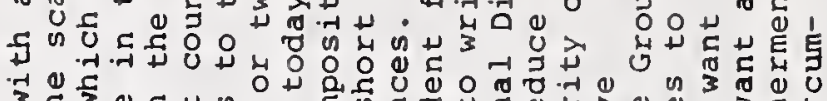

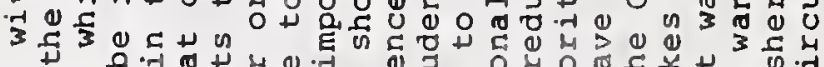

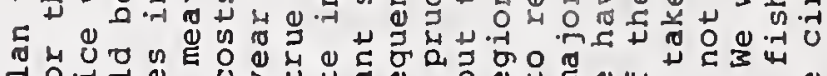

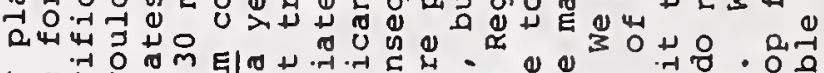

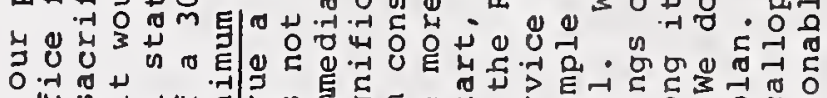

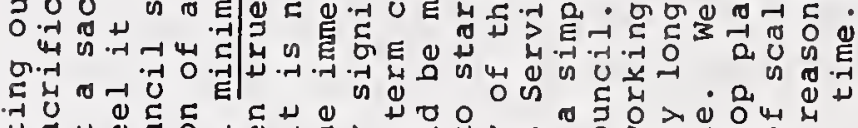

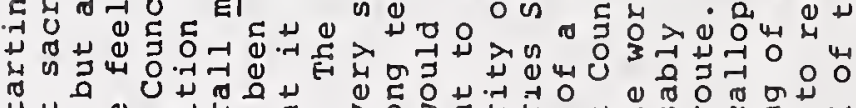

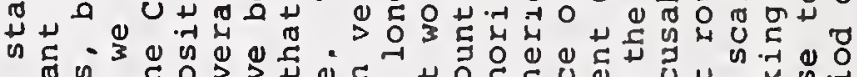

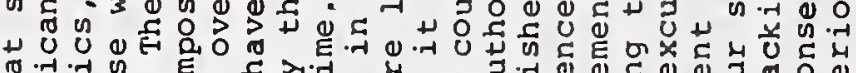

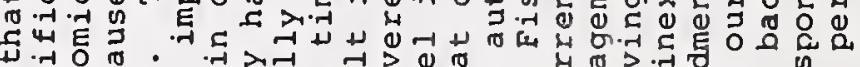

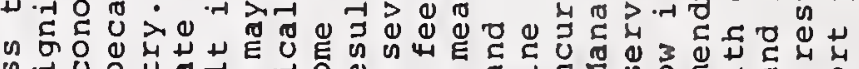

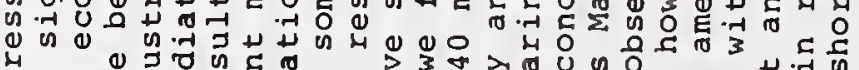
出

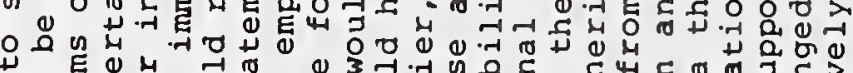

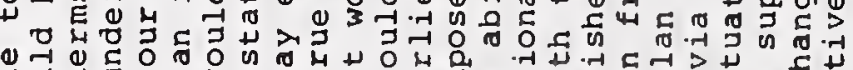
थ

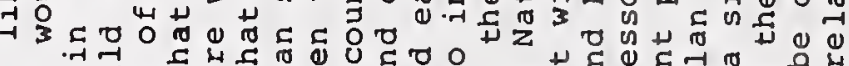

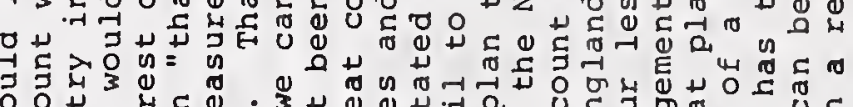

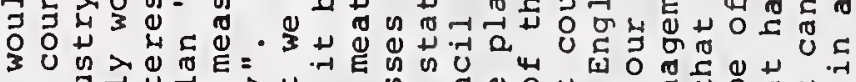
ט

可. C.

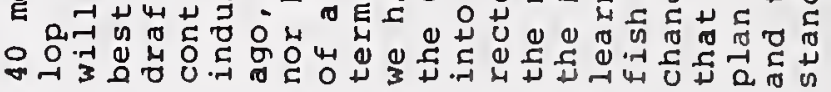

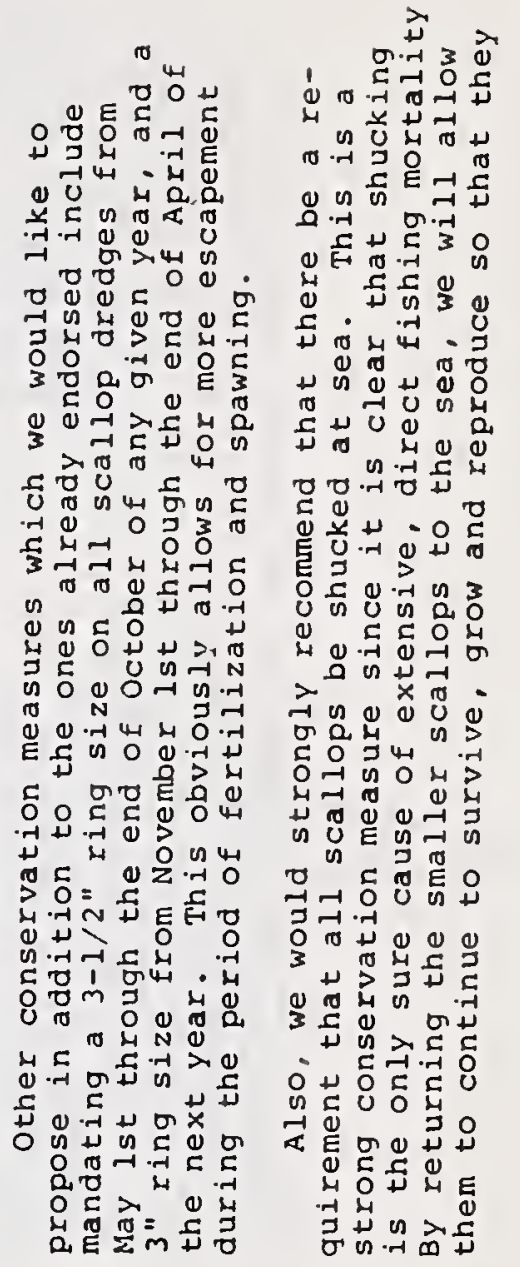

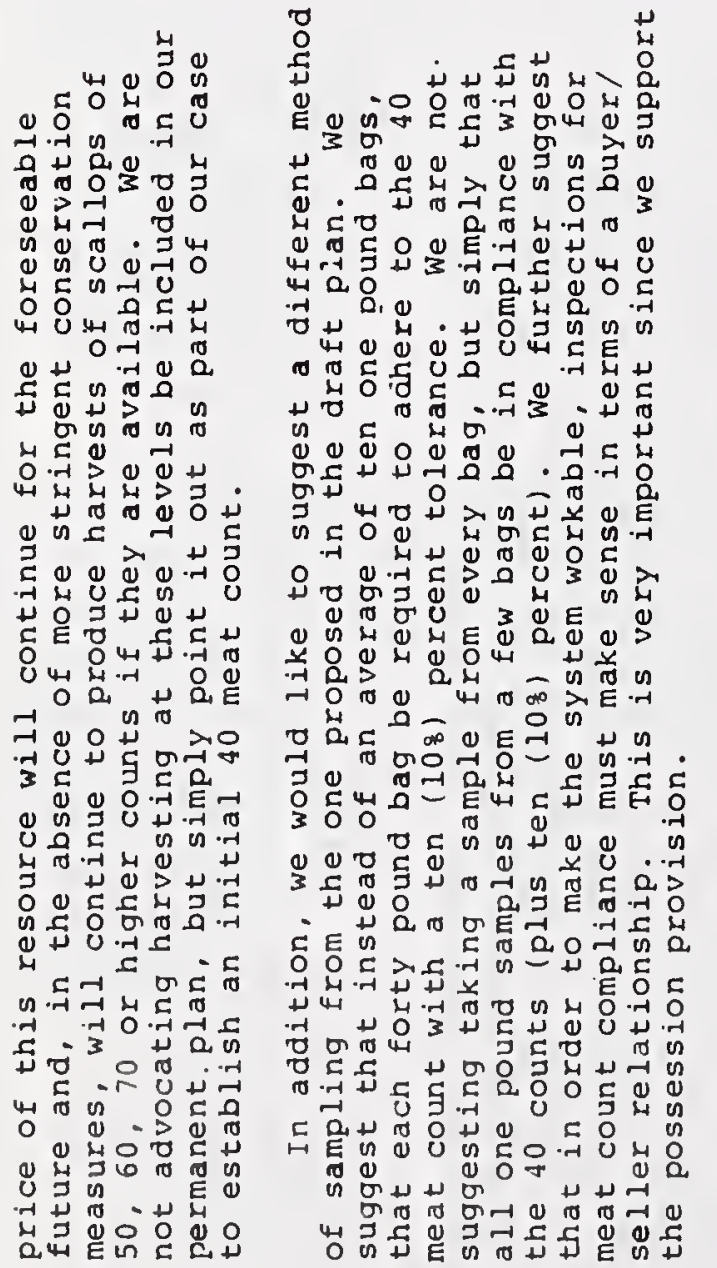

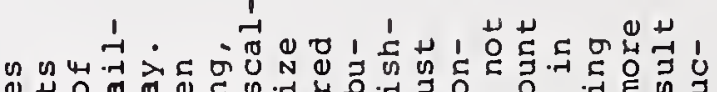

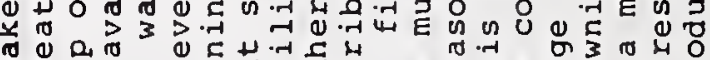

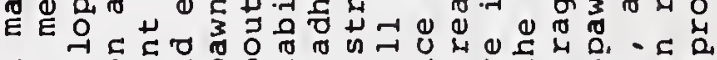

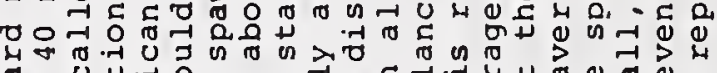

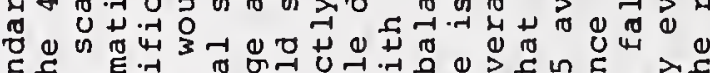

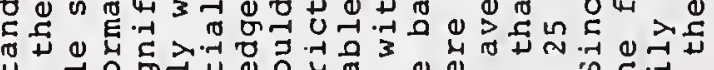

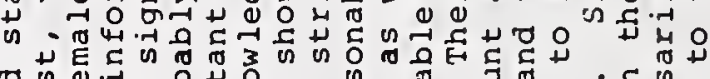

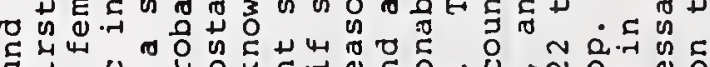

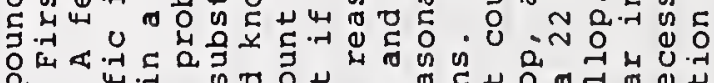

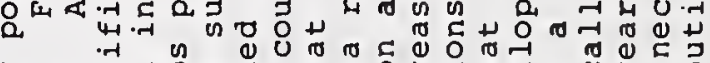

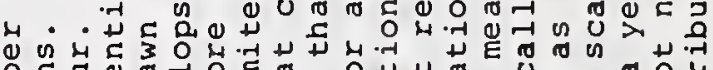
Q ᄃ

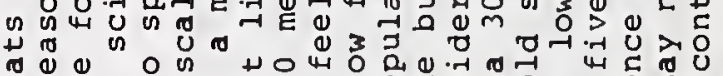

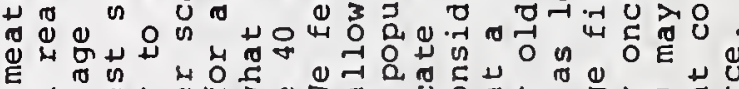

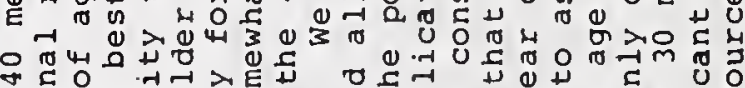
* ᄃ \%

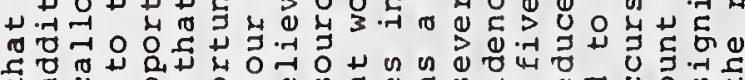

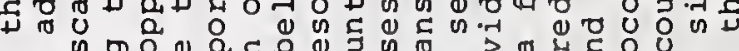

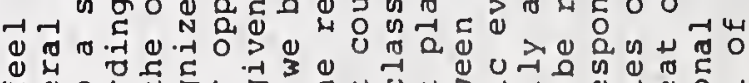

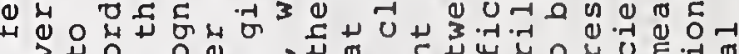

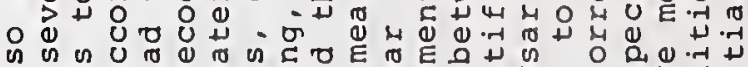
б山 б 0 의

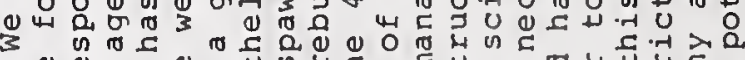

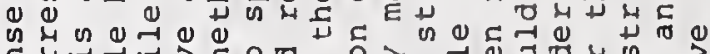

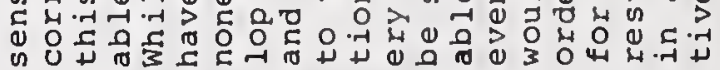

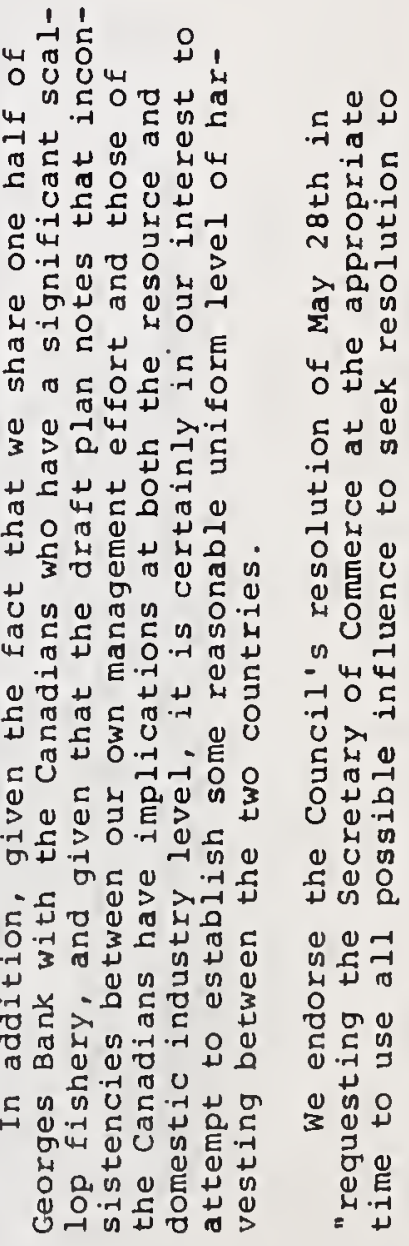




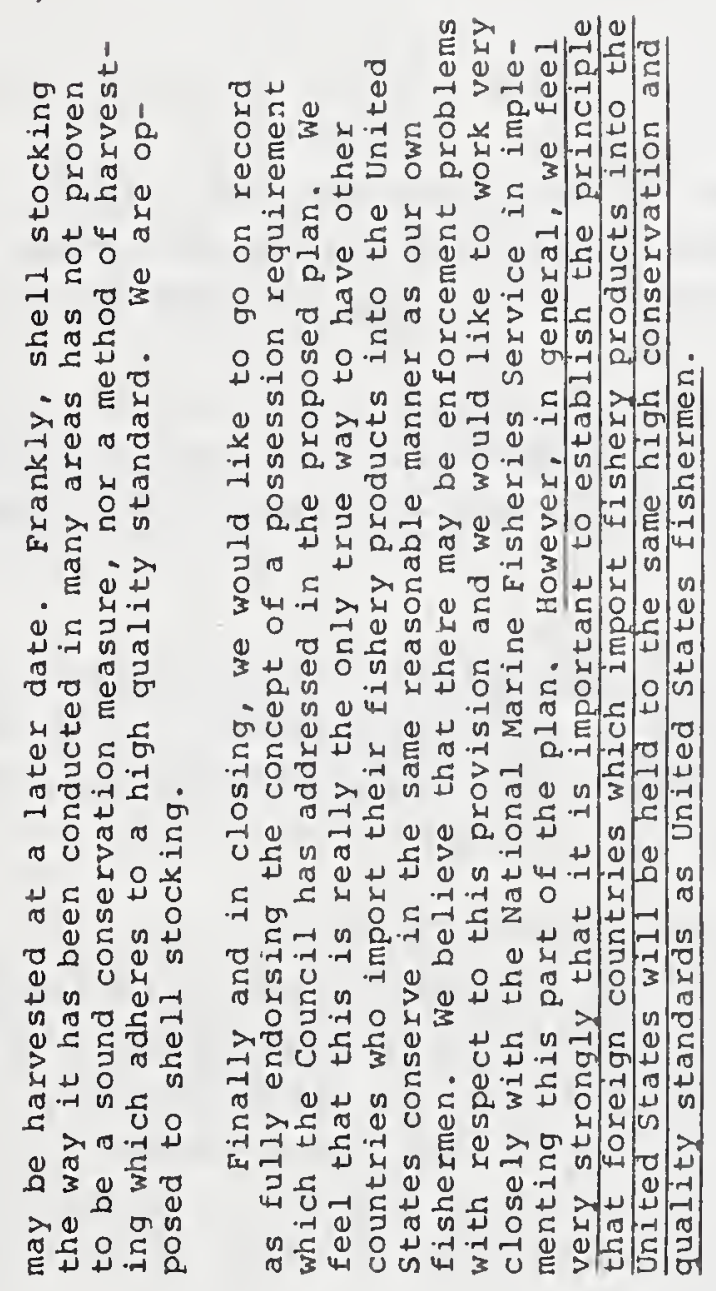

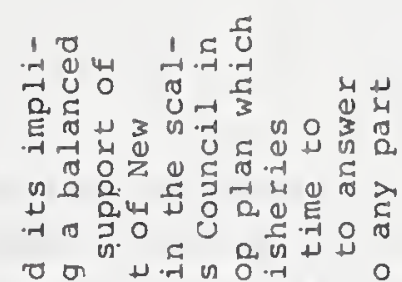

ชृ. 赵.

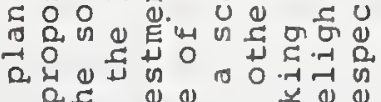
(1)

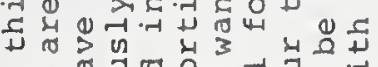

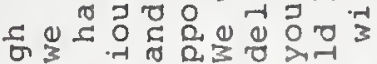

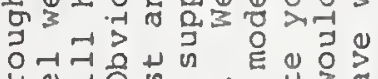

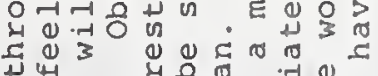
د

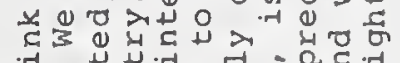
舟.

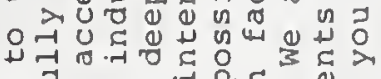

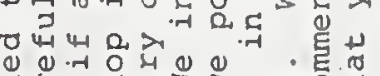

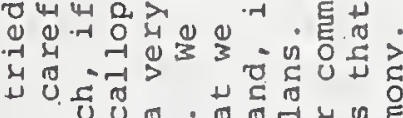
म

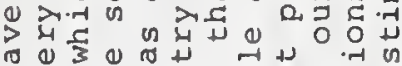

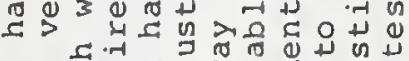

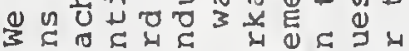

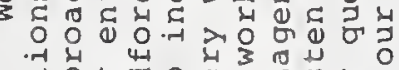

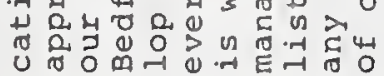


At a June 18, 1981, Committee meeting, the Staff drew five conclusions based on the public hearings and suggested options for Plan modifications. The conclusions were:

1) The industry supports the use of meat count as a measure in the FMP, but believes that the meat count adopted should not place U.S. harvesters at any disadvantage relative to imported scallops from Canada. Various resource and industry concerns were expressed in opposition to a 30 count U.S. standard. This opposition stems from (I) a current scarcity of 30 count scallops and (2) fear of being disadvantaged by imports of small scallops from Canada.

2) There was broad support for an initial minimum size of 40 meats per pound. However, when asked, industry members generally favored eventual decreases in the meat count, but only on the condition that such changes be reflected in Canadian regulations. In any event, there was general support for having the ability to make timely changes in the meat count standards as the Council perceived changes to be appropriate.

3) The industry generally supports a tolerance on the meat count standard. Most prefer the $10 \%$ tolerance value included in the Canadian regulation.

4) Representatives of the shellstocking sector of the fishery (principaliy from. Maine and North Carolina) prefer that the shell size equivalent of the meat count measure be in terms of a minimum size. Some shellstocking representatives also called for a tolerance on the number of shells that could be landed below the minimum size.

5) The industry strongly supports the concept of a prohibition on the possession of scallops of a meat count higher than that allowed by the plan at the point of first transaction in the U.S. Such a prohibition would apply to both domestically landed and imported scallops.

The Commitee recommended for Council consideration:

- 40 meat count average for vessels shucking sea scallops at sea effective upon initial implementation of the FMP; 30 meat count average for 
shucked scallops effective one year after implementation and thereafter until otherwise amended.

- 3 1/4" minimum shell height for sea scallops landed in the shell effective upon initial implementation of FMP; 3 1/2" minimum shell height for sea scallops landed in the shell effective one year after implementation and thereafter until otherwise amended;

- standard for recreational fishing same as for commercial vessels landing scallops in the shell;

(The recommended minimum shell height is expected to result in the corresponding average meat count when the scallops are shucked.)

- a $10 \%$ tolerance would be applied to the meats per pound measure:

- a $10 \%$ tolerance would be applied to the minimum size measure in both commercial and recreational fisheries;

(Procedures for sampling the catch to monitor compliance with the provisions of the plan will be specified in the regulations.)

The Committee recommends "possession at the point of first transaction in the U.S." be adopted in the FMP as the basis for monitoring compliance with the meat count/shell height management measures.

This language clarifies the intent of the Council regarding the implementation of the Plan's control measures. It eliminates uncertainty in monitoring compliance by clarifying the shared responsibility of the parties involved in the transaction and expanding the time frame for enforcement. In doing so, it enhances the effectiveness of the meat count/ shell height control measure for achieving Council objectives and conserving the resource. It is noted that the committee recommends that the Council staff work with the NMFS Regional office and Regional NOAA General Counsel staffs to develop appropriate language for implementing the council's intent regarding possession, particularly in view of possible implications for imported sea scallops.

\section{A significant review}

On June 15, 1981, the Council received the NMFS review of the DEIS/FMP (see letter) which focused on five critical issues "upon which plan approval is contingent". The FMP did not: 
June 12, 1981

Mr. Robert Jones

Chalrman

Hew England P1shery Management Counc1l

Suntaug office Park

Saugus, Massachusetts 01906

UNITED STATES DEPARTMENT OF COMMERCE

National Ocaenic and Atmospharic Administration NATIONAL MARINE FISHERIES SERVICE

Northeast Reglonal office

14 El in Street

Gloucester, Massachusetts alozo

Dear Bob:

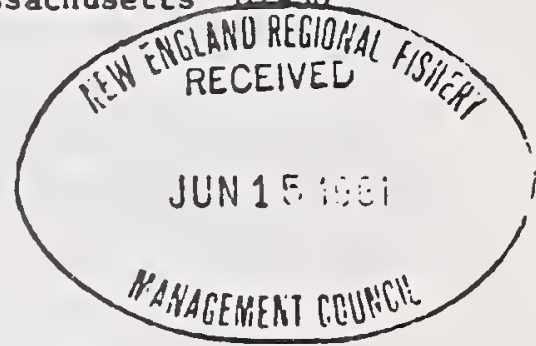

Th1s is to advise you of the completion of the National Marine B1sherles Service revlew of the New England P1shery Management Counc1l's draft F1shery Managment Plan for the Atlant1c Sea Scallop F1shery, and to provide you with our comenes.

The scallop plan is the victir of changed c1rcumstances, which 18 unfortunate, - Ince all of us are aware of the considerable tlme and effort, over a pertod now of several years, devoted by the Counc1l, Industry advisors, the Counc1l - taff, and the National Marine Flaheries Service. The changed c1rcumstances wll force us not only to extend our thlnking, but to 1mprove the plan and the management approach. Th1s should result in a more flexible plan which is both able to account for changing clicumseances and which 18 more versatile and efflcient for managing an extremely 1mortant flshery resource.

The results of public review of the plan are clear and suggest mofor modification of the plan. Unless we are able to decermi $\because$, and demonstrate that the proposed thirty meat count measure w1ll not sertussly 1 mpalr the vlabll1ty of large segments of the 1ndustry 1n the lmediate future, a less stringent inftial specification is indicated. I belleve we should begin with a meat count which provides some resource conservation benef1t, and bulld lato the plan flexibllity under established criterla wh1ch w1ll permit changes in that meat count specification as permitted by changes in resource avallabilty so that we can work towards an opt1mum conservation measure. Most of the enclosed comments discuss methods and requirements of such a flexible approach.

My staff and the staff of the Northeast Flsherles Center are avallable to cooperate with and assiat the Council in developing a flexible management program. If you or the staff have any questions, or need further clarification of our coments, please contact Bruce N1cholls, the plan coordinator.

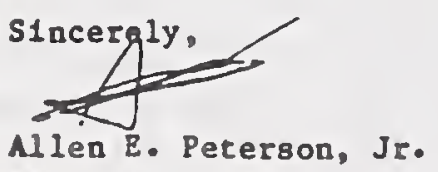

Reglonal Director

Enclosure 
1) discuss resource condition and fishery during the past year;

2) establish a management framework versatile enough to recognize or adjust for changes in the fishery similar to those recently experienced;

3) address consequences of Canadian activities on the fishery and on attainment of plan objectives;

$4)$ state clearly how each management alternative related to plan objectives. It was especially deficient in its analyses of immediate and short-term impacts of a 30 meat count;

5) provide a concise statement of rationale for the decision to select the preferred alternative.

Many other "deficiencies" were noted. The upshot of this review was that the timetable for getting the plan back to Washington was considerably delayed.

Extensive debate and varied opinions

At June 30 and July 1, 1981 meetings, the Council acted on Committee recommendations for Plan revisions. The first consideration was the meat count provision, and this raised many eyebrows. Some individuals, such as Jacob Dykstra, were concerned that the proposed action was totally inflexible in that the meat count automatically would decrease to 30 one year after plan implementation. Others, notably Nancy Goell of the Mid-Atlantic Council, argued that the 30 meat count should be implemented immediately for stock conservation and that the proposed $10 \%$ tolerance with a 40 meat count would effectively result in a too high 44 count. A New Bedford scallop industry representative, Roy Enoksen, countered that Canadians were fishing the small scallops; therefore, conservation was already being prevented.

To address the issue of flexibility, after extensive debate, the Council eventually voted to modify and accept a Staff suggestion provided in a June 12 memorandum. It decided to require:

40 meat count average for vessels shucking sea scallops at sea effective upon initial implementation of the FMP; 30 meat count average for shucked scallops effective one year after implementation except that the Council, upon a finding of fact that conditions warrant, may authorize the Regional Director to change the size limit.. Such 
changes would be based on pre-set criteria for a range of 40 to 30 meat count in increments of not more than 5 units at a time with a frequency of not more often than once every 12 months.

The record is clear that the Committee and then the Council were unsure of their intent regarding whether they wished to go to 30 meat count one year after plan implementation or to make the change optional, and whether they wanted the Council or the Regional Director to have the authority to make changes. The vote only indicated that the Council had agreed in principal with the strategy of beginning at 40 and going to 30 after a one year period. According to some Council members and the Staff, "There is nothing in the motion that now requires the Council to move from 40 to 30 meat count within any defined time period". This position was subsequently debated further at a July 17 Committee meeting and taken up again by the Council at its July 28 and 29, 1981 meetings.

Other positions taken at the June 30 and July 1,1981 meeting were that:

1) the 10 \% tolerance for the meat per pound restriction be eliminated;

2) the 10\% tolerance would apply to the minimum shell size measures in commercial and recreational fisheries.

3) no attempts be made to find means to accomodate state territorial and inland waters statutes relative to size limits and possession;

4) perhaps most importantly, the Council agreed that possession up to and including the point of first transaction in the U.S. be adopted as the basis for monitoring compliance with the meat count/shell height management measures, and the possession measure was an inseparable part of the Plan.

Meetings for clarifications

At its July 17 meeting the Committee decided that the move from 40 to 30 meats per pound with corresponding shell size changes ( $31 / 4$ " to $31 / 2^{\prime \prime}$ ) should be automatic after one year of plan implementation and that the flexibility in the measure should be exercised thereafter based upon a finding of facts by the Regional Director and concurrence by the New England Council and in consultation with the MidAtlantic Council. The meat count (shell size) was to remain at $30\left(3 \mathrm{l} / \mathrm{2}^{\prime \prime}\right)$ for at least one year. The frequency and meat 
count interval remained the same as previously decided. Changes in the meat count restriction by the Regional Director would occur automatically unless changes were specifically disapproved by the New England Council.

This intent was conveyed at July 28 and 29 Council meetings, and immediately this met with resistance. Harvey Mickelson sought to delete the automatic move to 30 meats per pound one year after the Plan was in place. He wished all changes in meat count to be optional; however, his efforts were in vain. Many Council members believed that if left optional, the count would remain at 40 one year after the plan was in effect particularly if industry did not favor the decrease in meat count.

The reader is referred to June and July, 1981, Council minutes for detailed accounts of deliberations (author cannot do it justice).

\section{A few changes before submission}

December 8 and 9, 1981 Council. meetings involved discussions and changes in the procedure for in-season adjustments in the meat count and minimum size. Utilizing Committee reccommendations, the Council approved the following judgement criteria:

"The decision to alter the management measure specification rests on a determination that the objectives of the Fishery Management Plan would be achieved more readily, or would be better served through an adjustment to the current meat count or minimum size. Specification may not be altered unless at least one of the following conditions exists in the resource, fishery or industry, subject to the condition that in no case would such an alteration result in a reduction in expected catch over the following year by more than 5\% from that which would have been expected under the existing management measure specification.

1) International inconsistencies exist in the management measures applied to sea scallop stocks in areas harvested by both domestic and foreign fishermen, and such inconsistencies provide foreign fishermen with an advantage over domestic fishermen that can be demonstrated to adversely affect the domestic fisherman;

2) Analysis of the size distribution of sea scallops shows that more than $50 \%$ of the harvestable sea scallop biomass is at sizes smaller 
than those consistent with the prevailing management measure specification and that a temporary relaxation of the specification would not jeopardize future recruitment to the Eishery.

Along with discussions on the appropriateness of these criteria was the reoccurring complaint that the Plan should not require an immediate move to 30 meat count one year after the Plan's implementation. James Costakes, in particular, chastised the council for this mandatory action. stated,

In defense of the Council's decision, Guy Marchesseault

"I can only respond to the extent that we have in the short-term analysis had an opportunity to take a look at what the resource is expected to look like in the next two years. This summer, the 1981 assessment has provided us with a good basis for projecting ahead for 1982 and 1983. It demonstrates to us that a move to a 30 meat count would not result in a significant impact. Moving to 30 is generating less than a two miliion dollar impact. We feel that whatever action it is will be insignificant and will not generally affect vessels shucking scallops."

\section{Final FMP submission}

On January 11, 1982 the final FMP was sent to William Gordon, Assistant Administrator for Fisheries (see letter). Draft regulations were to follow, and these were reviewed by the Committee at a January 25 meeting and approved by the Council during January 26 and 27,1982 meetings.

\section{Approval expected}

On February 24 and 25, 1982 meetings Douglas Marshall reported,

"The Scallop Plan was reviewed on Friday, February 19, 1982. The reviewers decided that the Scallops Plan is approvable, and there is every expectation that it will be approved. The region has recommended that the Scallop Plan be implemented on an emergency basis. The argument is that the 1979 year class coming up is very large. The scallops would be very vulnerable on Georges Bank. There is some additional work the staff has to do. The revisions are on the supporting documents, not on the plan. We are looking at the end of next week for completion. The target date for implementation is the middle of May." 


\section{NEW ENGLAND FISHERY MANAGEMENT COUNCIL \\ SUNTAUG OFFICE PARK, 5 BROADWAY (ROUTE I) \\ SAUGUS, MASSACHUSETTS OI9OB}

Mr. William G. Gordon

Assistant Administrator for Fisheries, NOAA

National Marine Fisheries Service

Page 2 Building

3300 whitehaven Street, N.W.

Washington, D.C., 20235

Dear MI. Gordon:

Enclosed for your review and approval under the Magnuson Fishery Conservation and Management Act is the Atlantic Sea Scallop Fishery Management Plan. Fifty additional copies are being sent to your office under separate cover.

This final version of the FMP has been carefully revised to address the issues raised by MFS on the March, 1981 draft (Peterson letter dated June 12, 1981). Further, various modifications have been made to the FMP reflecting the concerns raised at the series of public hearings held on the draft FMP/EIS in April of 1981. In particular, the Council has chosen to specify the meat count management measure at 40 meats per pound for the first year of plan implementation, to be followed immediately by a reduction in meat count to 30 meats per pound, with the provision that the meat count specification may be adjusted thereafter, within limitations, by the Regional Director. The Council believes that this revision to the plan is responsive to prevailing resource conditions, provides for meaningful resource conservation in the context of a continuing management program, and accomodates the need for a flexible and responsive manaoement system.

Bound with this FMP is a combined Final Environmental Impact statement and Regulatory Impact Review. The latter concludes that implementation of the Sea Scallop FMP is a "non-major" action for the purposes of Executive Order 12291. Specific sections of the EIS/RIR that support this conclusion have been highlighted in the document. We expect to be submitting draft proposed regulations shortly.

We have worked closely with the various offices of the National Marine Fisheries Service in the development of this FMP. We would like to thank you, Allen Peterson, and 8oo Edwards for the cooperation and careful attention given the Council in connection with the informal review and final drafting of these documents. We look forward to early approval of the FMP so that meaningful conservation and management of this important fishery resource may-proceed in a timely manner.

Sincerely,

New England Fishery Management Council Jacoo J. Dykstra

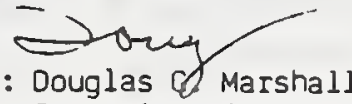

Executive Directo

GM/lg

CC: Allen E. Peterson

Council Members 
An accomodation for Canada

At an April 20, 1982 Council meeting, the Regional Director reported,

"The Scallop Plan is waiting for final signature. We expect that the emergency regulations will be agreed to and will be implemented around May 15, 1982. There have been ongoing discussions with the Canadians. We have tentatively agreed to accept certified Canadian products. We expect the Canadians to prepare a proposal, and we will then develop a memorandum of understanding. There has been no response received yet from the Canadians. If they don"t respond, then the regulations would apply to Canadian scallops the same as they apply to American scallops. We made it clear to the Undersecretary that their regulations would have to be consistent with our regulations. We recognize that someone would have to go first and that there would be a time delay. We have, however, managed to move closer to a common goal of scallop management."

A Canadian scallop export certification program was prepared by Canada. This program, acceptable to the Regional Director, was as follows:

1) Every scallop shipment for export from Canada will be accompanied by a serially numbered Government of Canada Certificate of Origin.

2) The Certificate shall include, as a minimum requirement, the following information:
a) Shipper and/or packer
b) Actual destination in the importing country
c) Date of shipment
d) Details respecting the amounts and product forms

3) In the event the shipment includes bagged scallops, which are not normally marked, the Certificate shall be certified by the Department of Fisheries and Oceans officer to the effect that the scallops in the shipment were caught by Canadian fishermen subject to Canadian scallop management regulations.

4) For bagged scallops, a self-locking, serialized, single-use, tamperproof Government of Canada tag will be affixed by the shipper in a manner that will necessarily destroy the bag 
or the tag after the initial and intended use. A description of the process and of the tags will be provided as soon as they are developed.

5) In the case of processed product (e.g., frozen, breaded), the Certificate will include all the details noted above except the certificate will not be signed. Note: the existing Fish Inspection Regulations presently in force require that processed products be labelled with the following information, requested by NMFS, i.e.,

a) Name and address of shipper

b) Product and weight

c) Product of Canada label

In addition to the above, there is also a regulatory requirement for all master cartons to be coded to identify the fish processing establishment, as well as the day, month, and year of processing.

6) In the event a shipment is to be delivered to more than one location, a separate Certificate will accompany each portion of the load.

A need to address Canadian concerns about the sea scallop Plan had been clear. Canadian fears were repeatedly expressed in their news media (see newspaper articles 9/17/81, 2/15/82, and $3 / 11 / 82)$. Additionally, poor Canadian landings and declining prices (see 6/15/82 news article) had especially fomented Canadian agitation over the Plan. Fortunately, the Certification Program appeared to dispel some Canadian criticism (7/1/82).

Declining stocks

Canadian (and U.S.) fishermen's observations on declining abundance of Georges Bank sea scallops were substantiated by NEFC assessments (see Serchuk, et al. 1982) which indicated,

"Despite recent increases in landings and total revenues, analysis of both commercial and research survey data indicate that resource abundance in almost all fishing areas had begun to decline."

and,

"The mean size of scallops sampled in 1981 from USA landings was the smallest in the 1965-1981 time series implying a significant reduction in cull size (size retained for market) in the commercial fishery." 


\section{Saturday, October 18, 1981 THE CHRONICLE-HERALD THE MAIISTAR Proposal could harm scallop market in U.S.}

\section{By MARZ YN MeedoNALD Staff Roportor .}

A propoual by the Now England Fisheries Management Council for management of the scallop fishery could endanger the Canadian reallop market to the Unitad States.

Roger Strlins, executive director of the Seafood Producer Aneciation of Nova Scotia (SPANS), said U.S. martets for the inshare coallop fishary could be wiped out, and the offshore scallop fishery's U.S. markets cut, if a proposal for scallop ranngement is ensctod lato tav.

Resposding to Candian requed tor come tyo of management regula. Hons in the American scallop fishery. the New England Fisheries Council proposed unplementing a meat count of 40 scallops per pound caught. That is similar to Ca. nadian regulations, but the problem oc curs when the Americans insist upos impoing that mast count to ceallops being exported to U. 8. curtamors.

Mr. stirtine cald that while Caradian colllos flethrmen mut bave an average af 40 reallops pes pound when they are lunded, the ceallops an then graded by gize to accommodate demands of cup tamars.

Some customers require smallar - rcallops so come packages exported to the United States may contain as many as 50 scallops per pound. The Amertean resulation treludes border checks to exp wre thare are no more than 40 scallops cor pound in a pacture.

This "posessiton Ilmit," as it is fenild, would effeetivily out out some ex. port trom the oxtahore conllop flathery

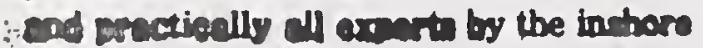

fichory, wueh as in the Bay of Fundy, - were the scallops never grow large enough for meat count of 40, Mr. Stirling sald.

"What they are doling in response to the Canadian initiative to ast for management measures is putting in management measures that hurt us."

He noted that what Canada initally asked the United States to do was limit entry to the scallop fishery, but that was turned down immedlately. Setting a meat count sinnllar to Canada's would ro duce the amount of rcallops the American ccallop ficharmen are taking from Georges Bank, putting Canads on an equal footing. But if they extend that management to border cheeks, It defents the entire purpose, Mr. stirling said.

The Canadian industry concerns wero put to American Ledustry officials lant weak durin a mecting botween the two caoupe in Boston. Whalle nothing was antled duriag the discuscion. the Ameri. can vore at least mode aware of the Canadian concerius. Mr. Stirling said.

He added that the meeting was held only to discuns the scallop management proposals and nothing was discussed eoncerning an intertm acreemeat on the Ceorges Bank tishery. Mr. Stjrling said that whlle as intorim agronment binding untll the boundary disputs is settled is cavoured by tho Canadian lathing ladur. try, it appoare impossible.

"The American contingant at last veak's meating said they did not want to discuss an interim agreement," he said.

Mr. Strling predicts that If Canada aprees to send the boundary dispute iswe to the International courts at the Hacue. it could be chree to fivo years be fors a deotidon is rendered. 


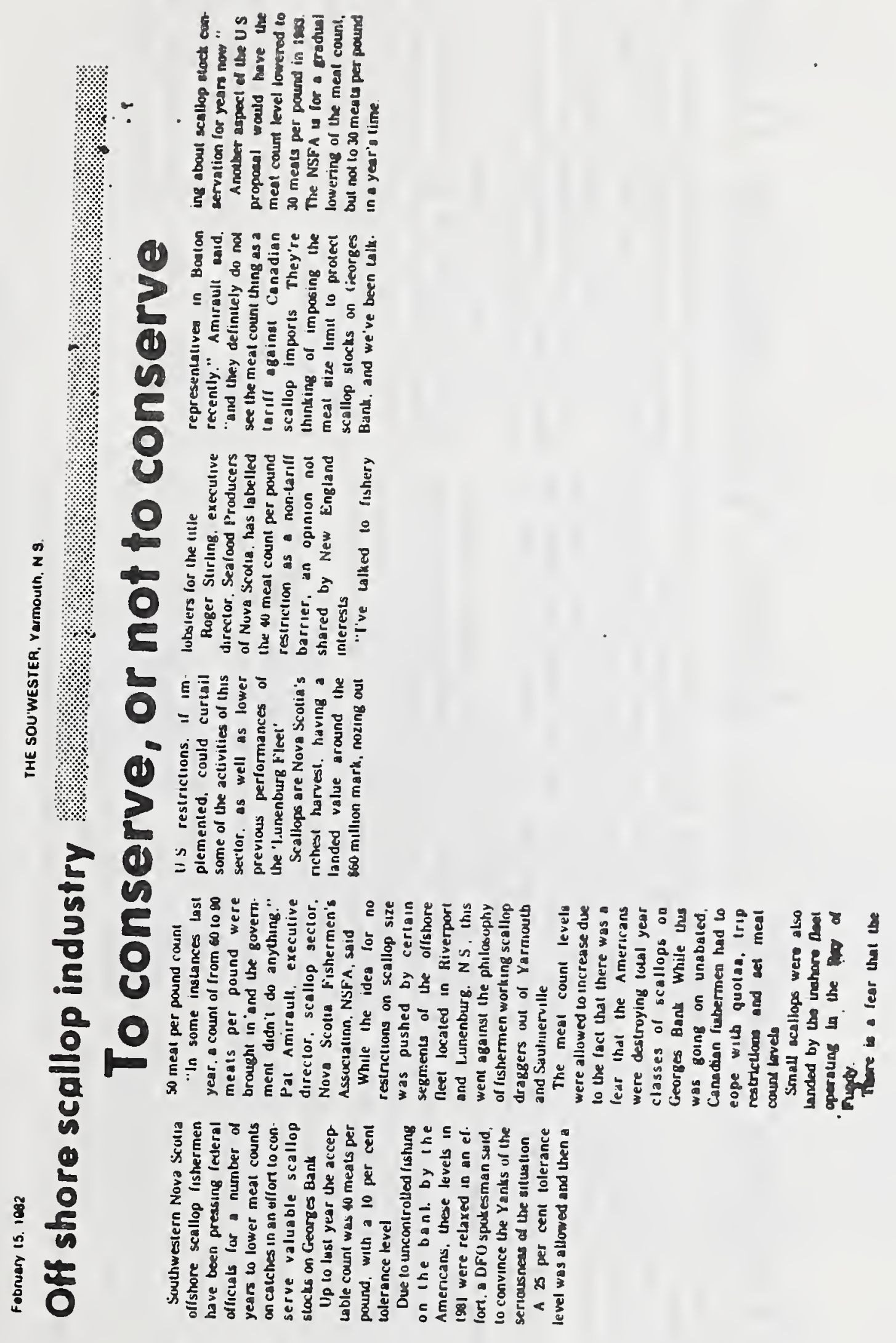


人

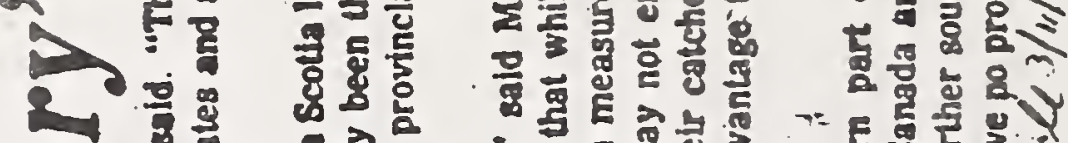

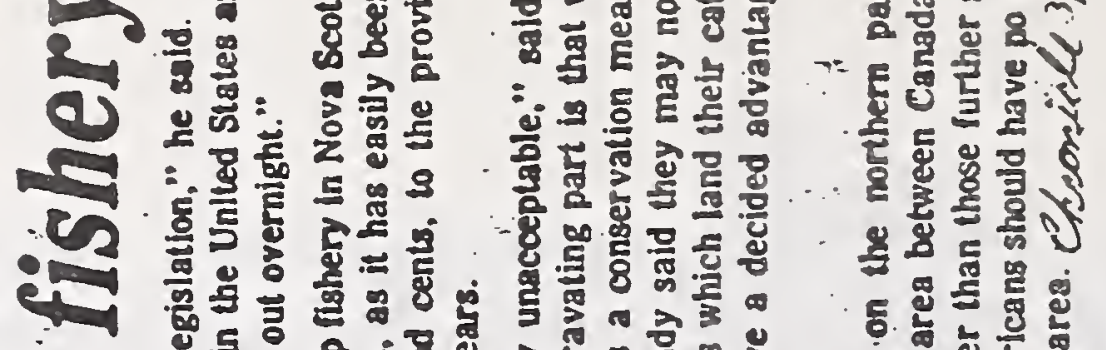

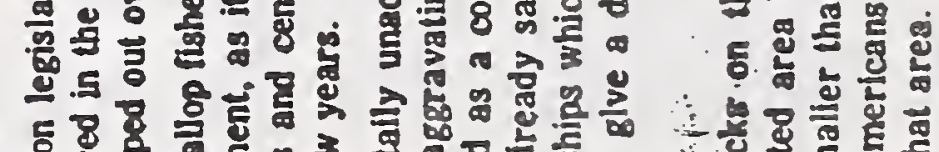

0 .

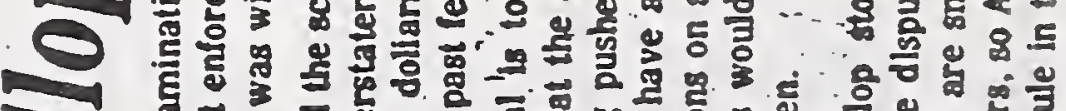

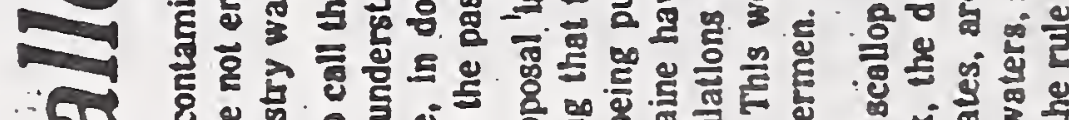

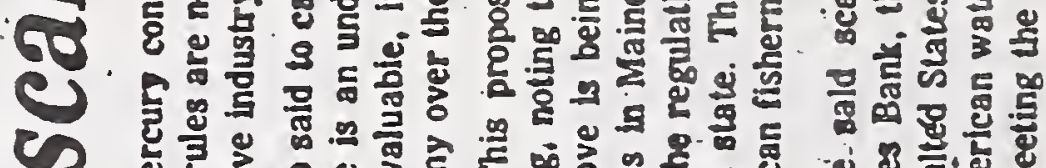

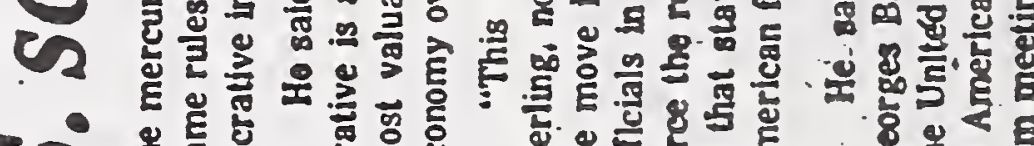

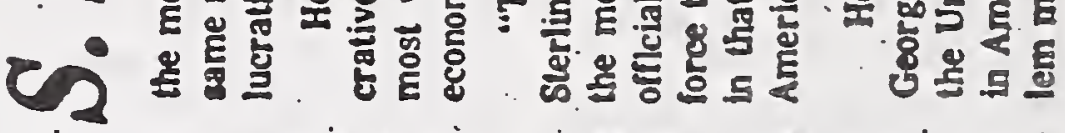

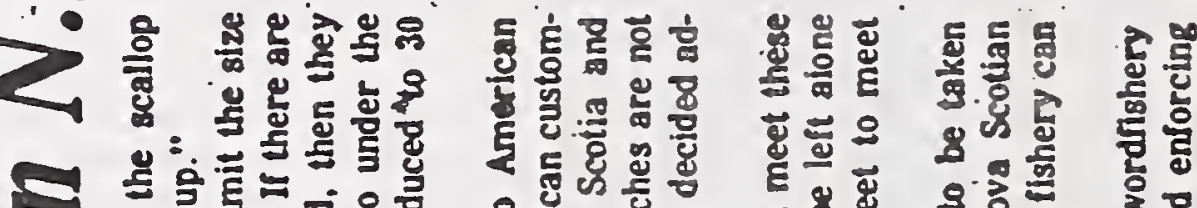

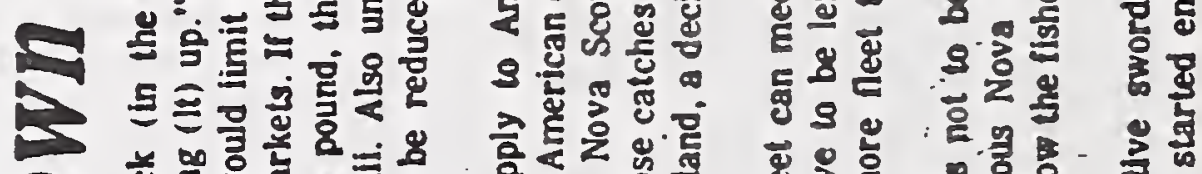

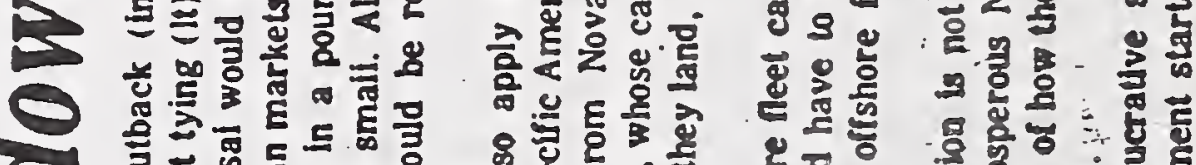

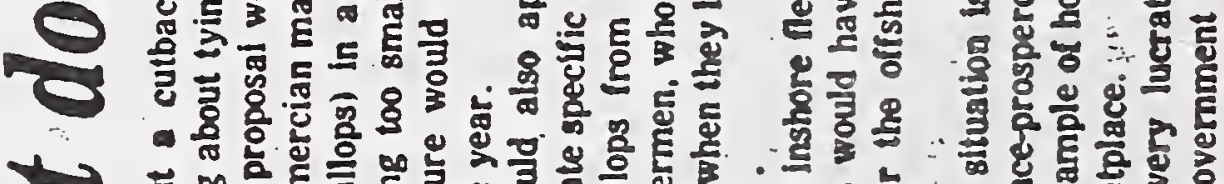

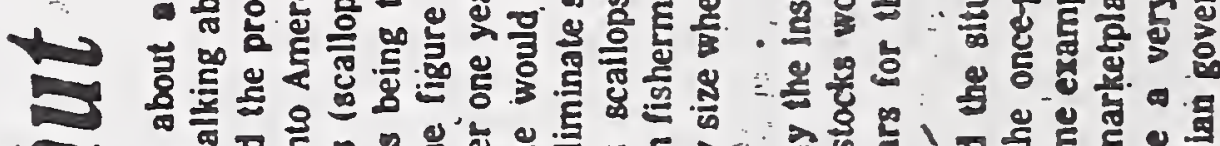

- 들

(2)

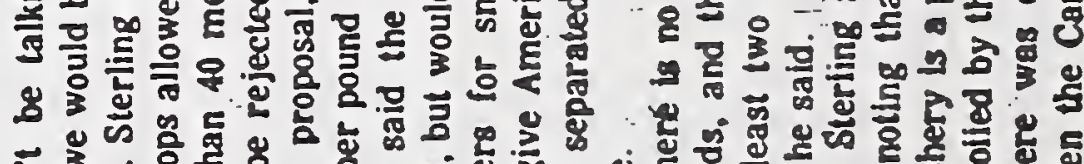

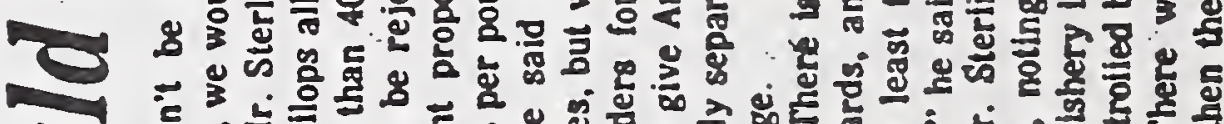

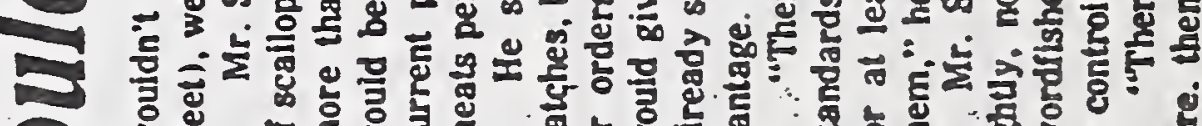

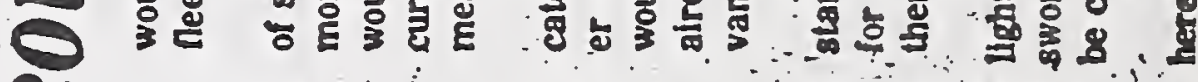

( ) \&

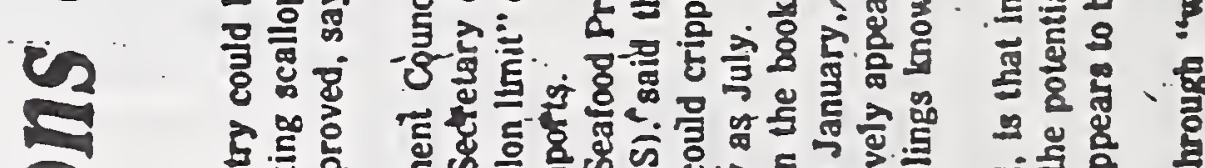

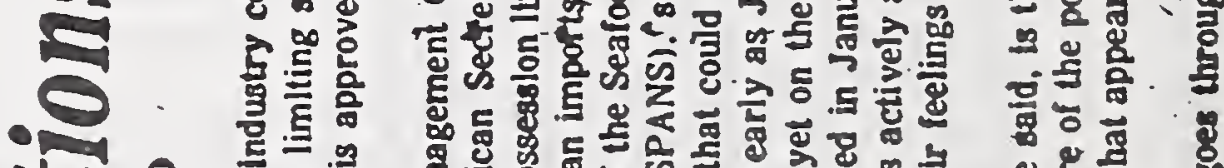

$\rightarrow$ 응.9

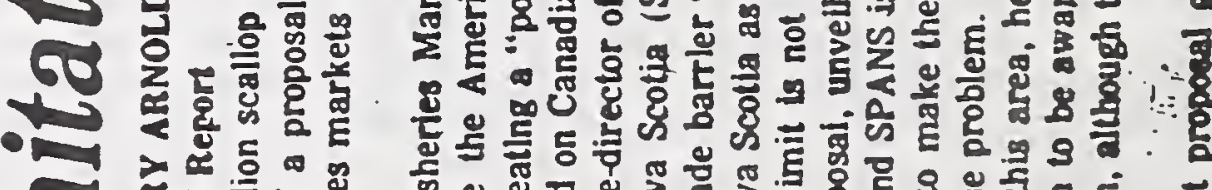

-

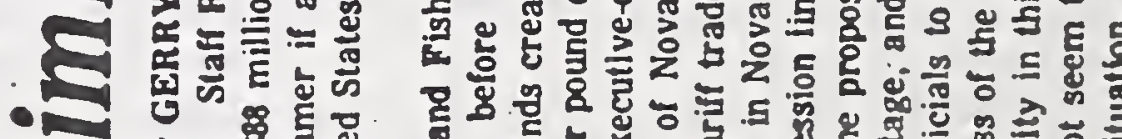

-

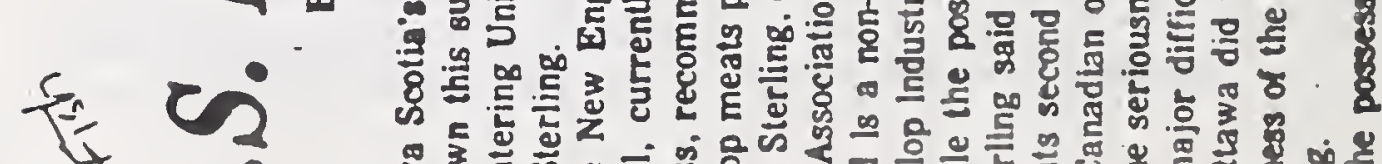

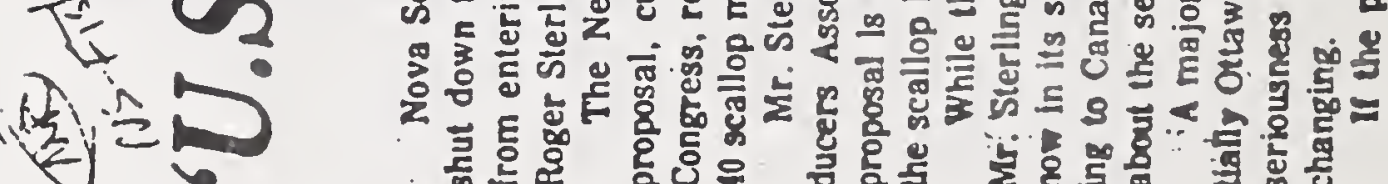

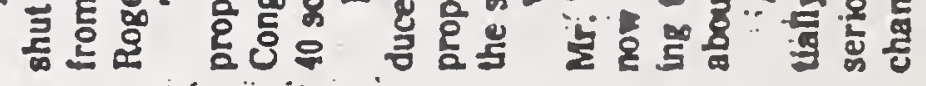




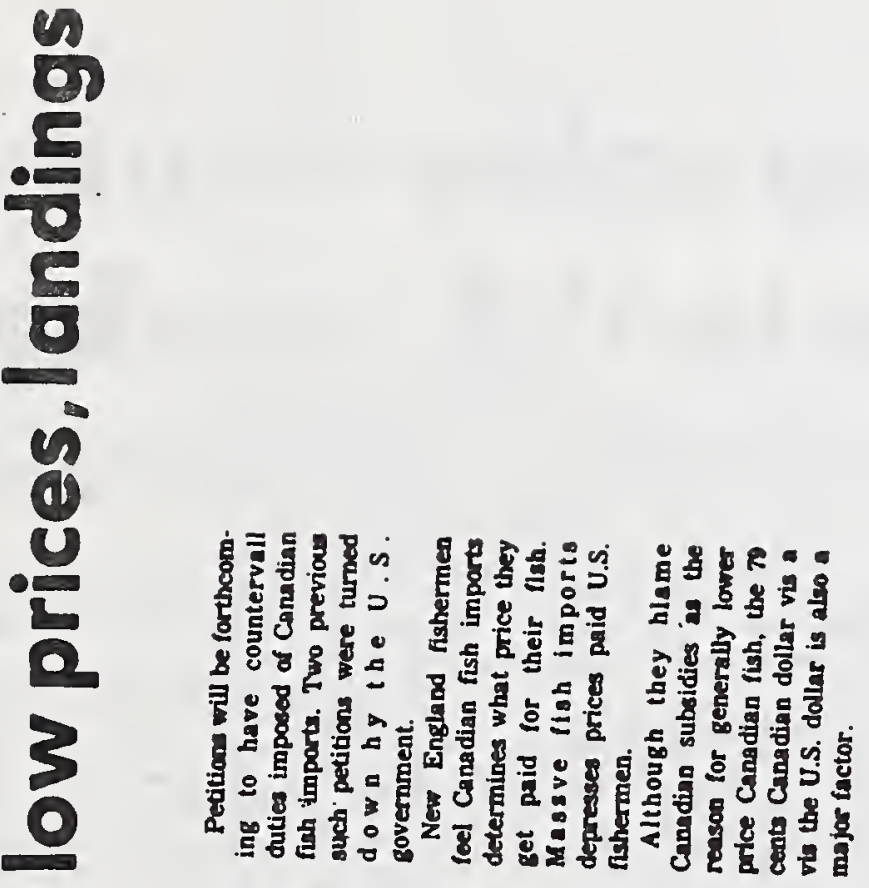

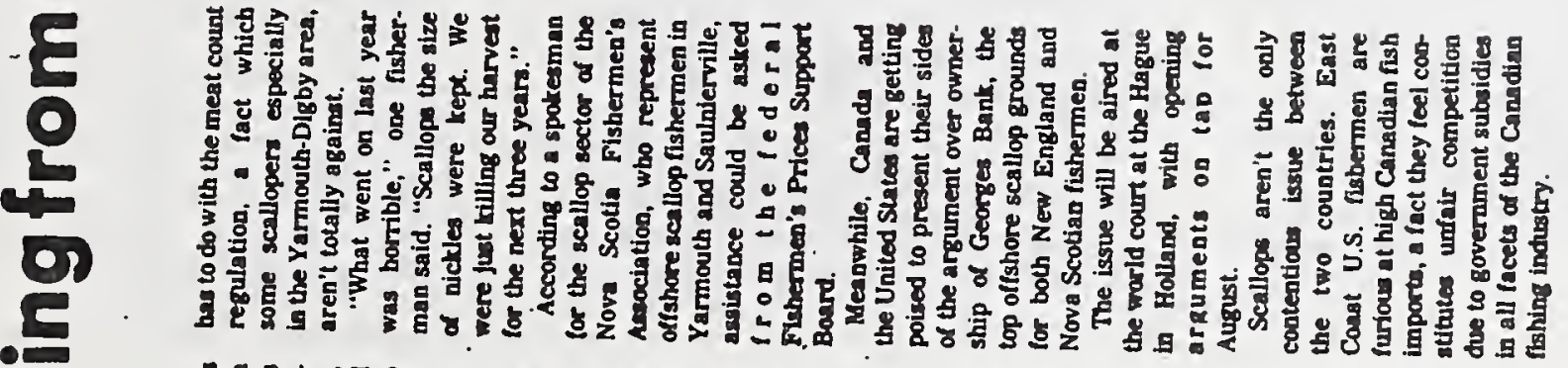

(1) E

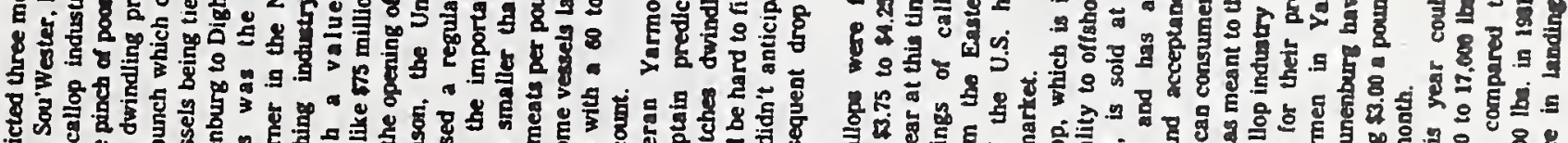




\section{Canadian scallop sales resume on normal basis to U.S. market}

It'8 now business as usual for Canadian scallop processors and their U.S. clients.

DFO Minister Romeo LeBlanc announced in Otlawa recently that the U.S. martet for Canadian scallops had been re-opened.

An American conservation plan called for a size limit of 40 meats per count on all scallops landed in the U.S. the restriction atso applied to Canadlan-caught scallops imported into the United Stares.

The meat count regulation was being applied at the . U.S. Canadian border. and Nova Scotian processors felt this was a non-tariff barrier which prevented ex. porters from filling specific orders in the U.S.

All this has changed and now all scallop shipments will be accepled in the U.S. as long as they carry certificates showing they were landed legally in Canada.

"We're naturally very pleased that the United States has adopted regulations to conserve this stock." DFO Minister Romeo LeBlanc said. "This is an important step in saving the very lucractive scallop fishery.'

Canada exports more than 80 percent of its scallop catch to the United States and sold 10.454 metric tons with a value of close to $\$ 100$ million to that country in ts31.
According to Kent Sweeney of Sweeney Fisheries in Yarmouth, the regulation change won't have too much effect on the Yarmouth and Saulnierville offshore neets.

"We basically stick to the $\mathbf{4 0}$ meats count, but the western shore fleet should benefit because they carry larger crews and need more scallops to make fishing trips worthwhile," he said.

The agreement struck between Cansda and the U.S. resea scallops looks like this: From June 15 to July 15 - 40 meat count with a $15 \%$ tolerance and afler July 15 . 40 meats with normal enforcement discretions.

Canada agreed to continue its trip and catch quolas and llcense limits.

The deal has some U.S. scallopers feeling that Canadian scallops smaller than the 40 meats regulation will be imported Into the U.S. and they are right, at least until July 15.

The agreement won't be discontinued until, both countries have been consulted about problems.

The new scallop regulations have run into some dilAculties, especially in Matos. As reported th the Commerelal Fishin News, a group of fishermen operating near Grand Manen are finding that while the scallepe they harvest are of or over the lesal shell size of $31 / 4$ inches, these scallops shell out a meat count as high an 00 per pound.

Over forty scallopers from the Jonesport, Maine, area are affected by the 40 meats ruling and recently met with Maine members of the New England fisher Management Council.

The New England Council plans to furtber reduce the meat count to 30 next year in a move to protect Eant Coast scallop stocts, a move which Nova Scotina scallopen have been hollering for for a long time.

Pat Amirault, executive director of the scallop seclor of the Nova Scotia Fishermen's Association is a bit peeved at the price members of his association are receiving for scallops.

Up until recentiy, Yarmouth and Saulniervill callopers were getting basically what New Bedford. Mass. fishermen were receiving. But of late New Bedford prices have soared while prices here have remained the same.

Fisbermeo In New Bedford receive $\$ 2.50$ to $\$ .00$ a pound, U.S., while southwestern Nova Scollan scallopers are attill receiving \$0.10. 
WOOOS HOLE LABORATORY REFERENCE DOCUMENT NO. 82-06

Review and Assessment of the Georges Bank. Mid-Atlantic and Gulf, of whinge Atlantic Sea Scallop (Placopecten magellanicus) Resources

Fredric M. Serchuk, Paul W. Wood, Jr., and Robert S. Rak

Sumnary

The USA Atlantic sea scallop fishery is one of the most important commercial fisheries along the eastern coast of the United States. Total annual USA landings during 1977-1981 from the Georges Bank. Mid-Atlantic, and Gulf of Maine resources attained record levels, averaging 12,800 metric tons of meats, the highest for any five-year period. In 1980 (latest data available), USA scallop landings generated 110.4 million dollars in ex-vessel revenues, an all time record. Despite recent increases in landings and total revenues, analyses of both commercial and research survey data indicate that resource abundance in almost all fishery areas has begun to decline. This report reviews recent fishery and resource conditions within each principal fishery region and provides an evaluation of these conditions relative to historical patterns and likely future events.

\section{Georges Bank}

Total international (USA and Canada) commercial landings in 1981 were 16,200 tons, $49 \%$ higher than in 1980 , and the third highest annual catch ever. USA 1981 landings were 8,200 tons, an increase of $46 \%$ from 1980 , and the highest yearly harvest in 18 years. Canadian 1981 landings totalled 8,000 tons, 53\% greater than in 1980 . More than $80 \%$ of the combined 1981 caten was derived from the Northern Edge and Peak region of Georges Bank. USA 1981 landings from this region were 4,306 tons, the highest since 1962, and accounted for $62 \%$ of the USA Georges Bank landings, nearly twice the proportional representation in the 1980 landings (34.5\%). Al 1 of the 1981 Canadian catch was taken from the. Northern Edge and Peak. Research vessel survey and commercial data indicate that exceptional recruitment of the 1977 year class, localized principally on the Northern Edge region, sustained the 1981 fishery. This year class was heavily exploited upon recruitment as evinced by the rapid rise and decline of commercial catch rates during January-September 1981 and the prevalence of smaller sized scallops throughout this period in both USA and Canadian catch samples. The mean size of scallops sampled in 1981 from USA landings was the smallest in the 1965-1981 time series, implying a significant reduction in cull size in the commercial fishery.

Total effort in the Georges Bank fishery during 1980 was the highest ever. Preliminary effort statistics for 1981 suggest that effort has remained high. Commercial catch per unit of effort (CPUE) of both fleets, however, declined by about $50 \%$ between 1977 and 1980 ; the 1980 USA CPUE index was the third lowest value in 37 years. Both USA and Canadian CPUE declines indicate that, prior to recruitnent of the 1977 year class in 1981, resource abundance had sharply diminished as a consequence of high fishing mortality rates. Fishing mortality is thought to have continued at high leveis during 1981 in spite of exceptional recruitment from the 1977 cohort.

USA and Canadian research survey total catch per tow indices declined in all areas on Georges Bank between 1980 and 1981. Survey indices from the South Channel and Southeast Part regions of the Bank declined by over $50 \%$; the 1981 total catch per tow value for each of these regions was the lowest in the 1975-1981 time series. Pre-recruit indices in both areas were also relatively low. On the Northern Edge and Peak, the 1981 survey data indicate that the 1978 year class is above-average in strength and will provide significant recruitment to the Northern Edge fishery in 1982. However, the 1978 cohort is believed to be oniy half as large as the 1977 year class and hence, under current fishing practices, will not sustain the level of landings supported by the 1977 year class.

Given the disparity in scallop abundance between the Northern Edge region and all other areas on Georges Bank, it is likely that both USA and Canadian fleets will continue to concentrate their fishing activities during 1982 in this area of Georges Bank. Under 1981 culling practices, this would result in meat counts in the 1982 fishery as high as those observed in 1981, al though the implementation of a USA sea scallop fishery management plan in May 1982 is aimed at ameliorating this situation by constraining the harvest of small scallops through meat count and shell size restrictions. Continuation of fishing strategies focused upon incoming recruitment will result in losses in both yield per recruit and reproductive potential, increasing the losses associated with growth overfishing and elevating the probability of recruitment overfishing. 
Gulf of Maine

Comatcial Gulf of Maine sea scallop landings in 1981 were 1,100 tons, 537 tons less than in 1980 , but still the second highest annual catch ever. As in 1980 , most of the landings $(-70 \%)$ were derived from offshore, FCZ waters from newly discovered beds. However, landings in 1981 were taken from beds much further nor:t.castward then those exploited in 1980. This shift in areal distribution of iandings connotes that fishery mortality in 1980 resulted in a rapid diminution of standing stock biomass in the areas exploited. Commercial effort in 1980 and :981 actained record levels, primarily due to increased activity oy Class 3 and 4 vessels. During 1965-1979, these vessel classes accounted for less than 10\% of the annual Gulf of Maine landings; in 1980, however, combined class 3 and 4 iandings comprised more than 60\% of the annual catch. Preliminary 1981 data suggest a similar pattern as in 1980. Reliance of the Gulf of Maine fishery on ofishore populations is a recent phenomenon. Before 1950, all landings were derived from inshore, territorial waters. During 1970-1978, inshore landings accounted for more than 87\% of the Gulf of Maine commercial sea scallop caten.

In 1980 , comercial size frequency sampling data indicated that the offshore fishery was sustained primarily by recruitment of the 1975 year class. Althcugh 1981 data show a substantial increase in the average size of scallop landas, it is likely that this increase is apparent rather than real due to low sampling intensity.

USA spring and autumn offshore bottom trawl survey relative abundance indices indicate differential scallop abundance in waters between 30-60 fin and 61-100 fin. In the former depth zone, catch per tow indices have been relatively stable since 1974. The 1980 and 1981 surveys indicate that the 1975 and 1976 year classes dominate the population. Most of the 1980-1981 offshore exploitation is thought to have occurred in depths between $30-60 \mathrm{fm}$ since the 1975 and 1976 year classes were predominant in commercial size frequency samples obtained in these two years.

In the 61-100 fin region, survey catch per tow indices in 1980 and 198 ! markedly increased from former years. Survey size frequency data indicate that abundance has improved due to a successful 1974 year class. Recruitment of the 1975 and $: 976$ year classes also appear to be above average.

Although the long-term productivity of scallop populations in the 5!-:00 fim region is unknown at present, the extremely high 1980-1981 survey indices sugges: that current densities may be sufficient to suooor: development of commercia? exploitation. Given that recent offshore landings have been largely suppor:ed by one or two year classes, and have been achieved by significant increases in ifshing mortality, it appears unlikely that current catch levels can be sustainea unless additional high density teds are located.

\section{Mid-Atiantic}

Total commercial 1981 Mid-Atlantic sea scallop landings were 2,100 tons, 59\% less than in 1980, and the lowest annual harvest since 1975. Commercial CPUE in 1980 was $34 \%$ lower than in 1979, 64\% lower than the peak 1977 index, and the third lowest value in the 1965-1980 USA time series. Despite the sequential annual decline in commercial catch rates since 1977, effort in the Mid-Atlantic has continued to increase reaching a record high in 1980. During 1981, Mid-Atlantic catch rates declined further precipitating a transfer of vessel operations to the Georges Bank fishery.

Commercial size frequency sampling data indicate a continued dependence in the fishery on larger-sized scallops (>110 mm shell height), reflecting the lack of any significant recruitment of the magnitude that sustained record landings during 1976-1980. Concomitantly, the extremely low 1981 commercial catch rates suggest that population abundance has substantially been reduced as a result of high fishing mortality rates during the past four years.

Research survey catch per tow indices during 1980 and 1981 exhibited similar trends. In the Delmarva and Virginia-North Carolina reglons, survey values have sequentially declined; the 1981 indices for both areas were the lowest in the 19751981 time series. Recruitment of the 1977 and 1978 year classes is relatively low in Delmarva and poor off Virginia-North Carolina. No evidence of successful recruitment of the 1979 year class was observed in survey tows in either area. Survey total catch per tow indices in the New York Bight region in 1980 and 1981 were about half of the 1975 index, and among the lowest values in the survey series. Prerecruit indices in both years suggest low to moderate recruitment from the 1977 and 1978 year classes. Recruitment of the 1979 year class may be better than these preceding cohorts since scallops from this year class were taken in the 1981 survey. Mormally, two-year-old scallops are rarely captured with the survey gear.

The absence of significant recent recruitment throughout the Mid-Atlantic area, in conjunction with high effort levels in the Mid-Atiantic fishery. will continue to impede improvement of resource abundance in the near future. Unless reductions in fishing effort are effected, overall scallop abundance is expected to further decline. 


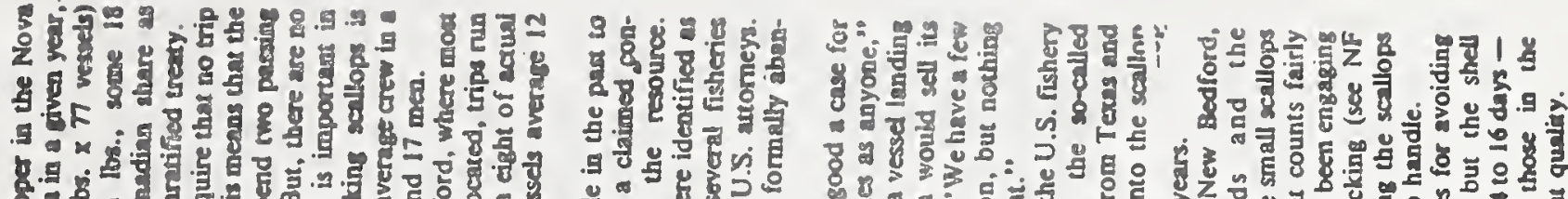

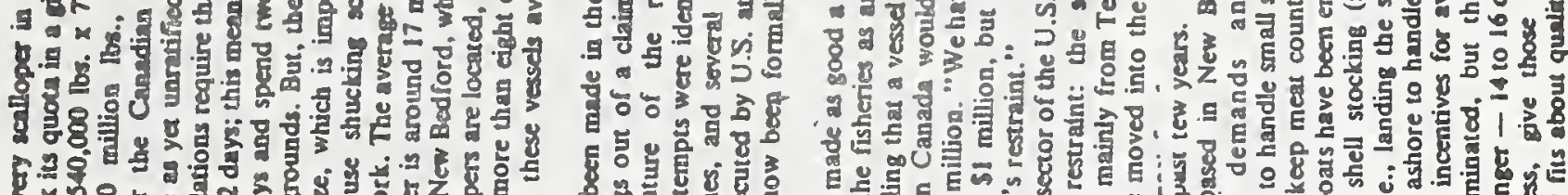

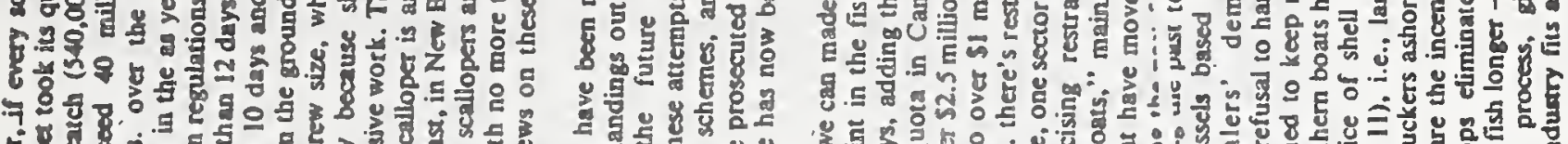
7.

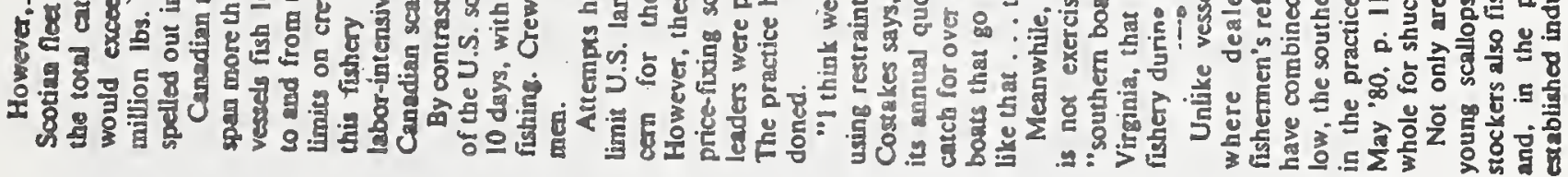

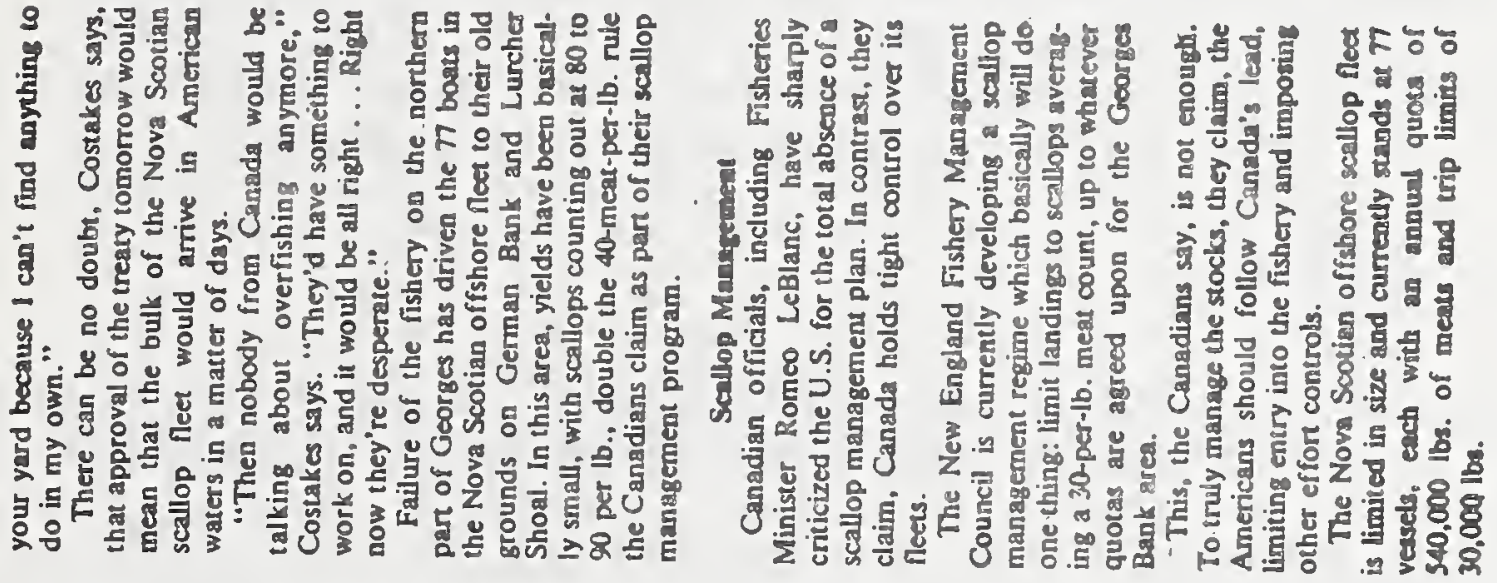

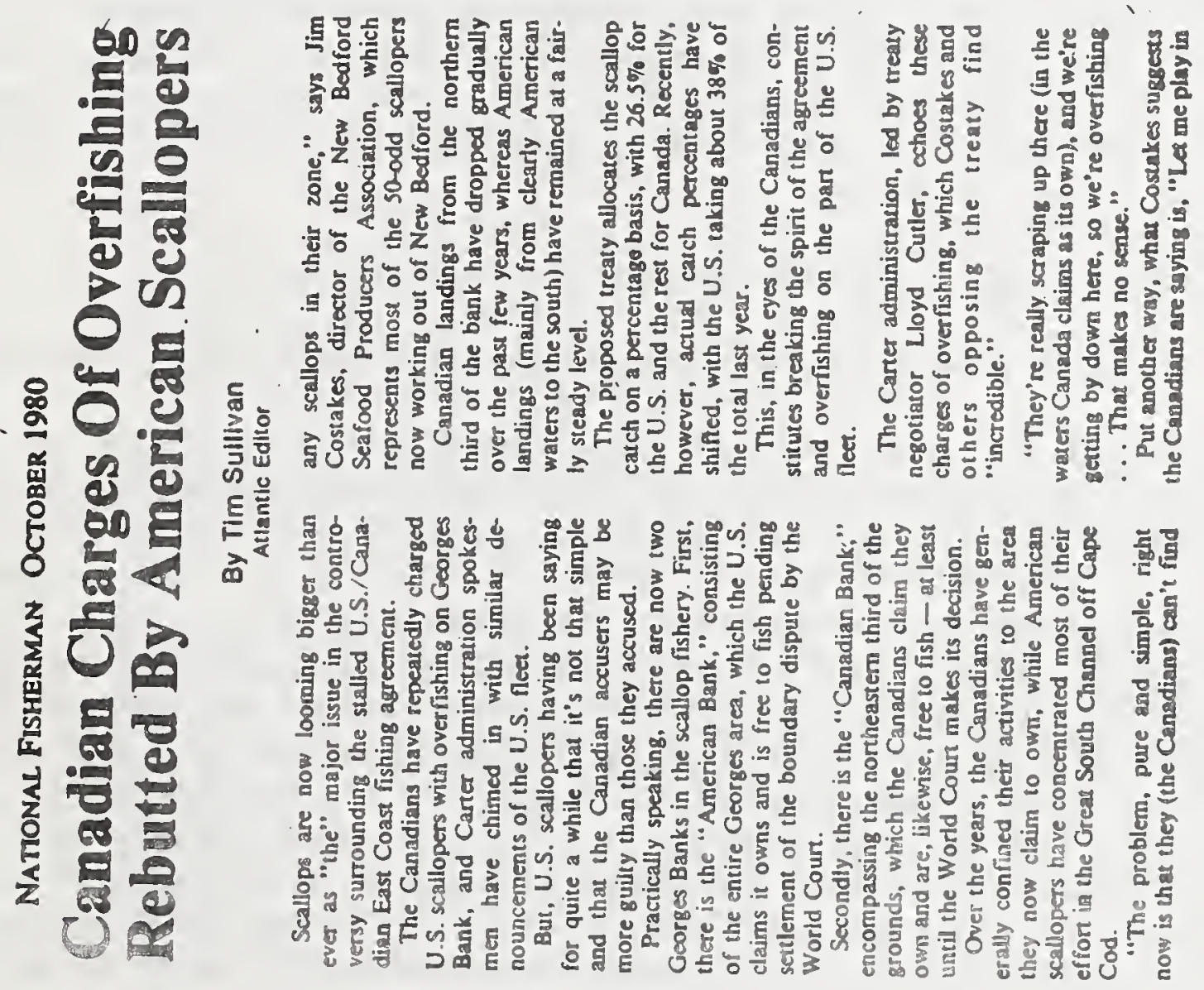


The issue of "overfishing" had long been a U.S./Canadian bone of contention with Canadian fishermen claiming U.S. "uncontrolled fishing" and "American total destruction of Georges Bank year-classes", and U.S. fishermen claiming that Canadian fishermen had overfished their own grounds (see October, 1980 newspaper article). Interestingly, one Canadian fishermen was quoted as saying, "What went on last year (1981) was horrible. Scallops the size of nickels were kept. We were just killing our harvest for the next three years." Regardless of which country's fishermen were to blame, the resource declined.

Emergency implementation

In a May 10 correspondence, the Council was informed by the Regional Director, that the Scallop Plan would be implemented on an emergency basis on May 15 (see letter). Sea scallop fishermen were informed of the implementation date by way of a May 13 correspondence (see letter).

Scallop Plan summary

The Sea Scallop Plan was implemented on an emergency basis effective May 15 to regulate sea scallop harvest throughout the range of the resource from Maine to North Carolina. Realizing that this range included several states' territorial and internal waters, the Plan encouraged states to adopt complimentary regulations to insure effectiveness of the Council's management program. Regulations implementing the Plan were to be in place until June 28 , and to be renewed for another 45 days until mid-August after which final, permanent regulations were to be issued.

Rationale for Emergency Implementation:

As stated by the Federal Register Announcement (50 CRF Part 650)

"Implementation of the FMP is time critical. In the spring of 1981 a very large year-class of scallops (a large number of maturing individuals) became available for harvest on Georges Bank, the center of sea scallop production. At that time, the scallops were extremely small, averaging 50-60 meats per pound. Many scallops were taken that spring by fishermen from both the U.S. and Canada, before they had an opportunity either to spawn or to grow to a size at which their meat yield approached its potential.

Another large year-class is expected to be available this spring on the portion of Georges Bank which currently sustains the bulk of the fishery. Without implementation of the FMP, these immature scallops will be harvested this spring. These regulations are being implemented on an emergency basis to protect these scallops immediately, to allow them to grow to a size at which their yield can contribute to the fishery and to enable them to enhance the fishery by spawning before being harvested.". 
UNITED STATES DEPAATMENT OF COMMERCE

National Oceanic and Atmosphorie Administretion NATIONAL MARINE FISHEAIES SERVICE

Northeast Reg10n

14 Ela Street

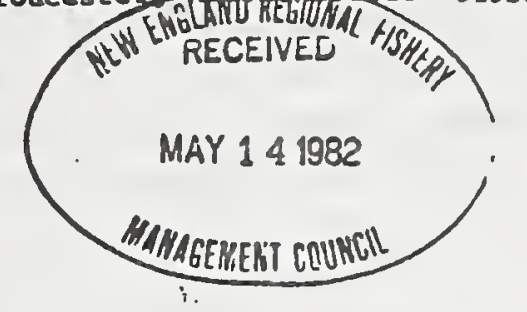

Der Federal F1aherles Perale Bolder:

The Flshery Mangenent Plon for the Atlantic Sea Seallop F1shary wes approved b) the Aalstant Adeialatrator for Flsherles on April 26, 1982, and will be Inplenented by energency regulations effect1ve May 15, 1982. The plan was developed by the New England P1sher Manageane Council in consultation with the MI-Aelentic and South Aelantic Counctis, and will regulate the harvest of sea scallopa, Placopecten magellanicus, wherever taken throughout thelr range, frow Malne through Norch Carolina.

The eargency regula:lons will continue in effect for 45 days, and way be reneved for an additlonal 45 days, after which final, permanent regulations w111 be 1ssued. Conments on the regulations will be accepted through June 28 , 1982, and should be directed to th1a address, marked "Sea Scallop Coments" on the outslde of the ervelope. Coples of the regulations will be forwarded to you on request, and co anyone who applies for a sea scallop permite.

The regulations implezent manigenent program which relles on a single conservation measure. The measure is a restriction on the size at harvest of sea scallops. For the first year of plan implementation, scallops must meet a standard of 40 meat count (average 40 meats per pound), or a corresponding 3$1 / 4$ inch $(83 \mathrm{~mm})$ shell helght. After that first year, the standard will rise to 30 meat count (average 30 meats per pound), or a corresponding $3-1 / 2$ lach (89ass) shell height Thereafter, the standard will remain at 30 meat count, except that the Reglonal Director may, under certaln circumstances, adjust the - tandard within a range of from 40 to 25 aeat count, in increments of five weat count, on a tenporary basis.

Enforcenent of the meat count standard will apply to sea scallops landed shucked and sold to a dealer up to the point in the U.S. where they are tixed, sorted, or processed. Sea scallops landed and sold in the shell must comply with the shell heighe standard up to the point in the U.S. where they are shucked. Sea scallops taken in Canada under regulations which are substantially consistent with U.S. regulatlons, will be admitted to the U.S. if they are properly labeled and accompanied by a certiflcate of compliance lasued by the Government of Canada.

All vessels harvesting sea scallops in quantitles greater than five bushels or 25 pounds of meats per er1p must obtain and carry on board a federal fisherles peralt with an endorsenent for the sea scallop fishery. Applications for the perale may be obtained in writing from P.O. Box 1109, Gloucester, Massachusetts 01930 , or by calling the Aralytical Services Branch at (617) 281-3600. There are no standards of ellgibil1ty for a permit, apart from providiag routlne lnformation about your vessel and geer.

4 volmears fishery inforention collection program will be used to obtalo Information frod fichermen for the purpose of managlag the flshery. Host see acallop flahermen currently provide the lntervlew and welghout 1 foormation requested under the program. The progran will be fully implemented in the near fueure a an action apart fron the sea scallop management plan.

$\triangle$ grace parlod of fifteen dajs, util June 1, 1982, wll be granted so that flaberwa car restrict thelr harrests to scallops which meet the meat count or shell helght seanderda. I grace period of alzty daya, until July 15, 1982, - will be granted to flohermn 20 that they can apply for, and recelve, the1s llabory pemerts. Anjone landlos sea scallope which fall to met the etandards after Jume 1,1982, or fishlins for sen scallops withour a valid permit on bosrd after Jaly 15, 1982, will be subject to enforcement act1on.

If you here" iny questlons about the management plan, the regulat1on, or any other aspect of the flshet, please call the Sea Scallop Management Coordlastor, Bruce N1cholls at (617) 281-3600.

Thants you fne jour ateeatinn and cooperation.

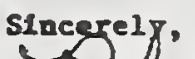

sincerel. 
Reasons for a Plan:

"Historically, landings from Georges Bank and the Mid-Atlantic areas have fluctuated. It is believed that high rates of exploitation may increase these fluctuations in the stocks, and in fact high rates of exploitation have typically preceded sharp declines in abundance.

The ability of these resources to support the current level of effort is questionable. Over the last several years the high abundance of sea scallops in all areas, coupled with increasing market value, have supported significant increases in fishing effort. In 1978 total removals (U.S. and Canadian) from the overall resource surpassed all historic levels. Data for 1979 and 1980 indicate declines in catch in spite of increases in overall effort.

Over-exploitation is a danger, in light of anticipated increases in demand. Consumer demand may be expected to support high ex-vessel prices, and thus, maintain an environment which encourages overexploitation".

Objectives:

The Plan has one overall objective with four sub-objectives. These are:

To maximize over time joint social and economic benefits from the harvesting and use of the sea scallop resource.

To reduce year-to-year fluctuations in stock abundance caused by variation in recruitment.

To enhance yield per recruit for each stock.

To evaluate the impact of Plan provisions on research, Plan development, and enforcement costs.

To minimize adverse environmental impacts on stock levels and utilization.

Optimum Yield:

Optimum yield has been defined as that amount of annual domestic sea scallop catch that results from implementation of the sea scallop fishery management program.

Management strategies:

The Plan relies on one basic conservation and management measure to achieve these objectives; that is, a meat count/ shell size restriction - maximum of 40 meats per pound (average value per trip) and minimum $31 / 4 "$ shell height (with a 10\% tolerance by number). This meat count and snell size is to be enforced, as provided by the Plan, through a comprehensive prohibition of non-conforming sea scallops up to and including the point of first transaction in the U.S. . 
Scallops are required to meet these standards unless they are certified to have been taken under a management system that is found to be "substantially consistent" with the standards and conservation objectives of the FMP. Procedures for certification are to be established by the Regional Director and he is to make the finding as to "substantial consistency" required for certification. The need for a certification process originated from discussions between the U.S. and Canada and is a means to address Canadian scallop export concerns.

After the Plan is in place for one year, the meat count restriction will be automatically increased to 30 meats per pound with a corresponding shell height of $31 / 2 "$. Thereafter, the Regional Director has the authority to change the meat count and shell size standard upon a finding of fact according to four criteria (below) and consultation with the Councils.

Criteria are:

1) The objective of the FMP would be achieved more readily or would be better served through an adjustment of the prevailing standards;

2) The recommended alteration in the standards would not reduce expected catch over the following year by more than 5\% from that which would have been expected under the prevailing standard;

3) The recommended standards for meat count and shell height are consistent with each other; and,

4) Inconsistencies exist in the management measures applied to sea scallop stocks in areas harvested by both domestic and foreign fishermen, and those inconsistencies can be demonstrated to adversely affect the domestic fishery; or, analysis of the size distribution of sea scallops shows that more than $50 \%$ of the harvestable sea scallop biomass is at sizes smaller than those consistent with the prevailing standards and that a temporary relaxation of the standards would not jeopardize future recruitment to the fishery.

The fact finding process can be originated either at the Regional Director's initiation or upon a request from the New England Council. Changes can only be made within a range of 25-40 meats per pound with corresponding shell sizes. This process allows changes in the standards without a formal, time consuming Plan Amendment. Action to alter the standard is subject to public review at a hearing scheduled for the same day as the Council meeting on which the recommendation is discussed.

Any vessel of the U.S. harvesting sea scallops in quantities greater than five bushels or 25 pounds per trip must have a permit on board the vessel. 
A voluntary fishery information collection system will be used to obtain information from fishermen for the purpose of managing the fishery (Three-Tier System). Dealer and processor data will also be collected as part of the system. 


\section{LITERATURE CITED}

Anderson, E. D., F. E. Lux, and F. P. Almeida. 1979.

The silver hake stocks and fishery off northeastern United States. NEFC, Woods Hole Lab. Ref. Doc. No. 79-28. $25 \mathrm{pp}$.

Serchuk, F. M., P. W. Wood, J. A. Posgay, and B. E. Brown. 1979. Assessment and status of sea scallop (Placopecten magellanicus) populations off the northeast coast of the United States. Proceedings of the National Shellfisheries Association. Vol. 69: 161-191. 
